\title{
Migration, Openness and the Global Preconditions of 'Smart Development'"
}

\author{
Arno Tausch** \\ Corvinus University, Innsbruck University
}

\author{
Almas Heshmati**** \\ Korea University
}

\begin{abstract}
We present a first empirical reflection on smart development,' its measurement, possible drivers and bottlenecks.' We first provide cross-national data on how much ecological footprint is used in the nations of the world system to deliver a given amount of democracy, economic growth, gender equality, human development, research and development, and social cohesion. To this end, we first developed UNDP-type performance indicators on these six main dimensions of development and on their combined performance. We then show the non-linear regression trade-offs between ecological footprints per capita on these six dimensions of development and their combined performance index. The residuals from these regressions are our new measures of smart development (a country experiences smart development, if it achieves a maximum development with a minimum of ecological footprint). We then look at the cross-national drivers and bottlenecks of this smart development and compare their predictive power using stepwise regression procedures. Apart from important variables and indicators, derived from sociological dependency and world systems theories, we also test the predictive power of several other predictors as well. Our estimates underline the enormous importance of the transfer of resources from the center to the periphery, brought about by migration, with huge statistical observed positive effects of received worker remittances on smart human development, Happy Life Years, smart gender justice, smart R\&D, and both formulations of the smart development index.
\end{abstract}

JEL Classification Numbers: C43; F22; F24; Q56;

Keywords: index numbers and aggregation, environment and development, environment and trade, smart development, sustainability, environmental accounts and accounting, environmental equity, population growth international migration, remittances.

\footnotetext{
* Comments and suggestions from an anonymous referee on an earlier version of this manuscript is gratefully acknowledged.

** Arno Tausch is a Visiting Professor of Economics at Corvinus University, Budapest, Adjunct Professor of Political Science at Innsbruck University, Austria, and Directorate-General for European, International and Social Policy Issues, A-1010 Vienna, Stubenring 1, Republic of Austria. E-mail: arno.tausch@uibk.ac.at

*** Almas Heshmati is a is Research Associate with Soran University, Iraq and a Professor of Economics in the Department of Food and Resources Economics at Korea University, Seoul, 136-713, Korea. E-mail: heshmati@korea.ac.kr
} 


\section{Göç, Dışa Açıklık ve “Akıllı Kalkınma”nın Global Önkoşulları}

\section{Özet}

Bu makalede, akıllı kalkınma, akıllı kalkınmanın ölçümü, etkileyen faktörler ve darboğazlar hakkında ilk ampirik bulgularımızı sunmaktayız. Çalışmada kullanılan veri, dünya sistemi uluslarının, belli bir demokrasi, iktisadi büyüme, cinsiyet eşitliği, insani gelişme, araştırma-geliştirme ve sosyal dayanışma seviyesini sunabilmek için ne kadar ekolojik ayak izi kullandıklarına dair uluslararası yatay kesit sunmaktadır. Bu amaçla, önce kalkınmanın bu altı boyutu için ve bunların kombine edilmiş performansı için UNDP benzeri performans göstergeleri geliştirdik. Ardından, kalkınmanın altı boyutu ve bu boyutların kombine edilmiş performans endeksi için, kişi başına düşen ekolojik ayak izine dair non-lineer regresyon ödünleşmelerini göstermekteyiz. Bu regresyonların artıkları, akıllı kalkınmanın yeni ölçütlerini oluşturmakta: Bir ülke eğer minimum ekolojik ayak izi ile maksimum kalkınma elde edebiliyorsa, akıllı kalkınmayı deneyimlemekte demektir. Bunun ardından, ulusların "akıllı kalkınması"nı etkileyen faktörleri ve darboğazları incelemekte ve bunların sahip oldukları öngörü gücünü adım adım regresyon metoduyla karşılaştırmaktayız. Sosyoloji kökenli bağımlılık ve dünya sistemi kuramlarından elde edilen önemli değişken ve göstergelerin yanı sıra, başka pek çok kestirim faktörünün öngörü gücünü de test etmekteyiz. Tahminlerimiz, göç nedeniyle kaynakların merkezden çepere olan transferinin muazzam öneminin altını çizmektedir. Ayrıca, işçi dövizlerinin; akıllı kalkınma, Mutlu Yaşam Yılları, akıllı cinsiyet eşitliği, akıllı araştırma-geliştirme ve akıllı kalkınma endeksinin iki göstergesi üzerindeki büyük istatistiki pozitif etkisini de ortaya koymaktadır.

JEL siniflandırması: C43; F22; F24; Q56

Anahtar kelimeler: endeksler ve veri birleştirme, çevre ve kalkınma, çevre ve ticaret, akıllı kalkınma, sürdürülebilirlik, çevre hesapları ve muhasebesi, çevresel adalet, nüfus büyümesi, uluslararası göç, işçi dövizi.

I $\mathrm{n}$ this article, we present a first empirical reflection on 'smart development', and its measurement and its possible drivers and bottlenecks. The very idea of smart development was first proposed by Meadows (1992). The basic idea was that we should relate our whole concept of development, and not just economic growth, to the natural resources needed to sustain it. In a similar vein, the Happy Planet Organization presented the so-called 'Happy Planet Index' (HPI), an index of measuring the trade-off between ecological footprint data and life quality (Happy Life Years, HLYE). Arguably, the ecological footprint today is the best single international yardstick for measuring environmental destruction in a nation (see also York, Rosa, and Dietz, 2003). In presenting possible theories explaining smart development, we deal in particular with the concept of 'openness' or 'world economic openness' and the issue of migration.

Economic theory takes into account the non-linearity of the trade-off between income and happiness, with rising income levels not necessarily increasing the happiness of all. This phenomenon has become widely known in the economic research literature 
as the 'Easterlin paradoxon' (Easterlin, 1995, 2001; Frey and Stutzer, 2002; Oswald, 1997; Stevenson and Wolfers, 2007). But here, we provide the first cross-national data including how much ecological footprint is used in the nations of the world system to deliver a given amount of democracy, economic growth, gender equality, human development, research and development, and social cohesion.

To this end, we first developed UNDP-type performance indicators from data on the six main dimensions of development (democracy, economic growth, gender equality, human development, research and development, and social cohesion) and on the combined performance in these six dimensions. We then show the non-linear standard OLS regression trade-offs between ecological footprints per capita and their square on these six components of development and the overall development performance index derived from them. The residuals from these regressions are our new measures of smart development: A country experiences smart development if it achieves a maximum of democracy, economic growth, gender equality, human development, research and development, and social cohesion, and the combination of them with a minimum of ecological footprint.

We then look at the cross-national drivers and bottlenecks of this smart development using standard comparative cross-national data. We compare the predictive power of these standard predictors, using standard OLS stepwise regression procedures. Apart from important variables and indicators derived from sociological dependency and world systems theories, we also test the predictive power of other predictors as well, ranging from geography and achieved development levels to the clash of civilization models, feminist theories, migration theories, and the 'small is beautiful paradigm' in the tradition of Schumacher.

The outline of the research includes a possible theoretical background, the measurement concepts and methodology, the results of drivers and bottlenecks to smart development, the results of earlier theories and relevant research, and finally our conclusions.

\section{Theoretical Background and Earlier Studies}

To present a theory or competing theories of smart development is virtually impossible because there has been no measurement of its cross-national successes and failures in the literature up to now.

In this presentation of possible theories explaining smart development, we now should deal with the notion of openness. Among the studies, we find these to be relevant: Alesina, Spolaore and Wacziarg (2000); Dollar, (1992a and 1992b); Edwards (1993); Frankel and Romer (1999); Rodrik (2006); Rodrik, Subramanian, and Trebbi (2004); and World Bank (2005). Dollar's writings were especially straightforward in suggesting that a high share of exports and imports per GDP, and hence an outward orientation, is especially beneficial for economic growth and that it works in favor of the poorest strata of the population. The study by Frankel and Romer (1999) comes to a more cautious conclusion regarding the direction of causation between trade and income. According 
to that study, the countries' geographic characteristics, however, have important effects on trade. Frankel and Romer then construct measures of the geographic component of the countries' trade to estimate the effect of trade on income. They suggest that trade has a quantitatively large and robust positive effect on income.

Rodrik, Subramanian, and Trebbi (2004) further shattered the optimistic assumptions about the beneficial effects of world economic openness on development outcomes in their study about the respective contributions of institutions, geography, and trade in determining income levels around the world. Their results indicate that 'the quality of institutions "trumps" everything else' (Rodrik, Subramanian, and Trebbi, 2004). Once institutions are accounted for, conventional measures of geography have at best weak direct effects on incomes. Similarly, once institutions are accounted for, trade is almost always insignificant, and often enters the income equation with the "wrong" (i.e., negative) sign. Rodrik (2006) fundamentally questions the 'Washington Consensus' based on open markets which featured so prominently in Dollar (1992a and 1992b).

The issue of migration equally divides opinions around the globe and among the global social science research community. ${ }^{[1]}$ As is well-known, migration is part and parcel of the 'four freedoms' of capitalism including those of goods, services, and capital. It is only logical to treat its possible influence on smart development. Migration assures continued production and hence also pollution in the migration recipient countries; while worker remittances might contribute to overall consumption, well-being and investment in environmentally more sustainable housing and heating systems in the migration-sending nations. A survey of the hitherto existing migration theories (Massey et al., 1993) came to the pessimistic conclusion that migration theories were either advanced to explain the initiation of international migration or were put forth to account for the persistence of migration across space and time. Massey et al. suggested that the theories are not inherently logically inconsistent.

As Taylor pointed out in his summarizing policy statement on the state of migration theory for the United Nations in 2006, indeed it would be foolish to exclude migration from any future discourse about global development: The number of international migrants has increased more or less linearly over the past 40 years, from an estimated 76 million in 1965 to 188 million in 2005. The flow of international migrant remittances has increased more rapidly than the number of international migrants, from an estimated US $\$ 2$ billion in 1970 to US $\$ 216$ billion in 2004 . Nearly $70 \%$ of all remittances go to LDCs. As Taylor also pointed out in a number of other studies, especially in 1999, worker remittances affect the less developed sending countries by a multiplier effect, well-known in economics since the days of John Maynard Keynes (Taylor, 2006: 9). The optimistic view about worker remittances is also supported by Ziesemer (2009). The author shows that the countries with per capita income below $\$ 1,200 /$ year benefit most from remittances in the long run because they have the largest impact of remittances on savings, investment and steady-state growth rate. All these effects are much weaker for the richer countries.

1 Appendix Tables 1a and 1b highlight the theoretical dimensions of this paper. Among the many existing theories, we highlight here especially migration and its possible links to smart development. 
The UNDP HDR 2009 edition maintains that financial remittances are vital in improving the livelihoods of millions of people in developing countries. There is a positive contribution of international remittances to household welfare, nutrition, food, health and living conditions in the migrants' places of origin. Even for those whose movements were driven by conflict, their remittances helped entire war-affected communities to survive. In some international migration corridors, money transfer costs have tended to fall over time. Recent innovations have also seen significant decreases in costs at the national level. With the reduction in money transfer costs, formal channels are more frequently used. Important functions of remittances include diversifying sources of income and cushioning families against setbacks such as illness or larger shocks caused by economic downturns, political conflicts or climatic vagaries (UNDP HDR, 2009: 72). Similarly, the UNDP also maintains that there should be significant aggregate gains from movement, both to movers and to destination countries in the form of increased population, employment and GDP. Migrants bring broader economic benefits, including higher rates of innovation. Data from the United States show that skilled migrants boosted innovation. The aggregate effect of immigration on the wages of local workers may be positive or negative but is fairly small (UNDP, HDR, 2009: 84-85).

Summing up the debate, we refer to the findings of Jeffrey Williamson (2002): that showed that mass migration made an important contribution to late nineteenth century convergence in the 'North.' In the absence of mass migration, real wage dispersion would have increased by $7 \%$, rather than decreased by $28 \%$, as it did in fact. GDP per capita dispersion would also have decreased by only $9 \%$, rather than by $18 \%$ as it did in fact. Wage gaps between the New World and the Old would have risen to $128 \%$ in 1910 when in fact they declined from 108 to $85 \%$. Real wage convergence before World War I was attributable to migration, to about two-thirds of the GDP per worker convergence, and perhaps to one half of the GDP per capita convergence. There was an additional and even more powerful effect of the mass migrations on global income distribution.

Sanderson (2010) was one of the first consistent research attempts to bring in migration as a determining variable of social well-being. Contemporary levels of international migration in less-developed countries are raising new and important questions regarding the consequences of immigration for human welfare and well-being. Sanderson's contribution was to assess the impact of cumulative international migration flows on the human development index using a series of panel data models to estimate results in a sample of less-developed countries for the period 1970-2005. Those results indicate that higher levels of international migration are associated with lower scores on the human development index, but that the effect is relatively small.

In terms of thoroughly tested scientific knowledge, the next possible alternative theoretical tradition to fill the explanatory gap for smart development accounting would be a dependency and world systems theory. Although its effect on the mainstream economic scholarly journals has been marginal, it has had a very wide impact on the leading international sociological and political science journals. Insufficient space does not permit us to debate at greater length this very vast literature, centered on the subject of MNC (multinational corporation) penetration and economic and social development. 
Rather, we concentrate on what was actually predicted in the Bornschier/Chase-Dunn/ Rubinson study (1978) that analyzes the effects of MNC penetration on economic growth and income inequality:

'(1) The effect of direct foreign investment and aid has been to increase economic inequality within countries. (2) Flows of direct foreign investment and aid have had a short-term effect of increasing the relative rate of economic growth of countries. (3) Stocks of direct foreign investment and aid have had the cumulative, long-term effect of decreasing the relative rate of economic growth of countries. (4) This relationship has been conditional on the level of development of countries. The stocks of foreign investment and aid have had negative effects in both richer and poorer developing countries, but the effect is much stronger within the richer than the poorer ones. (5) These relationships hold independently of geographical area.' (Bornschier/Chase-Dunn/ Rubinson, 1978: 651)

Important later tests of these hypotheses, taking into account the most influential control variables like initial income levels ${ }^{[2]}$ did nothing but support and refine the original argument, independent of the research design for different indicators, time periods, samples and methods (see inter alia: Beer, 1999; Bornschier, 1982, 2002; Dutt, 1997; Heshmati, 2006b; Kentor, 1998; Klitgaard and Fedderke, 1995; Tausch, 2003; Tausch and Prager, 1993; Tsai 1995).

Center-periphery models in the tradition of Prebisch $(1950,1983,1988)$ and the classical dependency theories of the 1950s, 1960s and $1970 \mathrm{~s}^{[3]}$ all can be important elements in the debate about smart development. All these theories claimed that the relations of dependency block long-run economic growth and bring about a socially unbalanced development, short spurts of economic growth notwithstanding.

There has been a real growth industry of blossoming and booming dependency, and with it an increase in world-system oriented studies of environmental problems during the last years. It has become fashionable in many traditions of sociology and political science to blame the lack of sustainable development on globalization and the workings of global capitalism, perceived as a center-periphery system. The central question, posed by Meadows (1992) and by the Happy Planet Index methodology, is how much footprint was consumed in the nations in order to deliver a given amount of development.

Nevertheless, the relatively coherent tendency of these studies ${ }^{[4]}$ suggests that there

2 There is also a conventional economic theory of growth accounting, and income inequality practices for such controls. For the convergence effects of poor countries growing faster than richer ones, see Barro, (2003).

3 The different perspectives include such as Amin's five monopolies of power, Frank's re-orient model, Mariategui's perspective and in the tradition of such authors as Cardoso (1977, 1979), Cardoso/Faletto, (1971), Furtado (1963, 1964, 1976, 1983), Sunkel (1966, 1973, 1978), and the quantitative research inspired by these theories, namely by Galtung, (1971), Sunkel (1973) and later Chase-Dunn (1975), Bornschier/Chase-Dunn/Rubinson (1978) and Bornschier/BallmerCao (1979).

4 Most notably Dick and Jorgenson (2010), Jorgenson and Burns (2007), Jorgenson (2003, 2004a, 2004b, 2005, 2006a, 2006b, 2007a, 2007b, 2008, 2009a, 2009b), Jorgenson, and Burns (2004), Jorgenson, Dick, and Mahutga (2007), Jorgenson, Kuykendall, and Kennon (2008), Lawrence (2009), Longo and York (2008), Mostafa and Nataraajan (2009), Mostafa (2010a, 2010b), Nugent and Shandra (2009), Shandra (2007a, 2007b), Shandra and London (2008), Shandra, Leckband, and London (2009), Shandra, Leckband, McKinney, and London (2009), Shandra, London, Whooley, and 
seems to be a strong causal interaction between transnational capitalist penetration and environmental degradation, especially in third world countries. To date, the most important counter-study to this school of thought was the essay by Ehrhardt-Martinez, Crenshaw, and Jenkins (2002) which analyzed deforestation rates from 1980 to 1995 in the developing countries, using ordinary least squares regression. Considering the total outcome of the controls for the initial forest stock and the quality of deforestation estimates, the authors find strong evidence for an 'environmental Kuznets' curve ${ }^{[5]}$ driven by (1) agglomeration effects linked to the level of urbanization, (2) rural-to-urban migration that partially offsets rural population pressure, (3) the growth of services-dominated urban economies, and (4) strong democratic states. The authors find little evidence that foreign debt or export dependence influenced the deforestation rate.

A number of high-profile studies in economics have used other control variables (see also Appendix Table 1a and 1b), while the sociological profession seems to be more cautious about their use. ${ }^{[6]}$ The Kuznets curve of economic inequality (Barro, 2000) or environmental degradation (Selden and Song, 1994; Stern, 2004; Stern, Common and Barboer, 1996) must be just as mentioned in this context as is shown in the study by Biswas and Ram (1986) on military expenditures. Also see Ram (1997) on tropical climate; the sociological study by Crenshaw and Robison on population, demography, pre-industrial heritage and socio-linguistic integration as factors of economic growth (also Easterly, 2000; Poe and Tate, 1994); Ram (1986) on government expenditures, and Scanlan (2004) on women in government and on food security and social development (see also UNDP, HDR, 1995). Further references from the perspective of feminism and good governance include Holmberg, Rothstein and Nasiritousi, 2009; Logo, 2008; Matt, 2010; McDowell, 1992; Rankin, 2002; Rothstein and Teorell; as well as the survey on women in government and the welfare state in Orloff, 1996. We also should mention culture (for membership of a country in the Islamic Conference [now: Cooperation]see the debate following Huntington, 1993; and by contrast Amin, 1997). A more detailed account of earlier important studies is given in Appendix Table 1b.

Confronted with all this startling variety of contradictory statements on the drivers and bottlenecks of international development, we now present a survey of the empirical methods used in this study.

\section{Methods and Measurements}

A brief description of the smart development data and its sources can be accessed electronically. ${ }^{[7]}$ Our investigation duly acknowledges many of the key determinants

Williamson (2004), and finally Shandra, Shor, and London (2008, 2009).

5 The Kuznets curve rests on the idea, proposed by Kuznets (1955) that developmental outcomes (like inequality) are a non-linear function of development levels.

6 Interested readers are also referred to Easterly (2000, 2002), Easterly and Levine (1997), and Heshmati and Tausch (2007) for further reference.

7 All the original variables are available at: http://www.hichemkaroui.com/?p=2017 and http://www.hichemkaroui. $\mathrm{com} / \mathrm{p}=2383$ \#more-2383 
of economic growth mentioned in the economic literature. Of these sources, we refer to the current shares of the country's inhabitants in total world population; to the famous Heritage Foundation 2000 Economic Freedom Score; to absolute geographical latitude in the UNDP figures for long-term annual population percentage growth rate, 1975-2005; to the trade-off between development level and development performance in the simple Huntingtonian fact of whether a country is a Muslim country as measured by the Organization of Islamic Conference (now: Cooperation) (OIC) Membership or by the Muslim population share (Nationmaster), and to the UNDP data on the simple geographical fact of population density and the public education expenditure per GDP and education index, combining the enrolment rates at the primary, secondary and tertiary education levels. We also take into account figures on military expenditures per GDP and data on military personnel rate which are key variables of contemporary political science international relations theory and peace research. In our analysis, we also show the theoretical and practical (political) potential of the following two drivers of development, migration and European (Monetary) Union membership.

To gain a real empirical knowledge under scrutiny here, we first developed UNDPtype indicators on six dimensions of development and on their combined performance. We then show the non-linear standard OLS regression trade-off between ecological footprint per capita and its square and these six dimensions of development and the overall development performance indices. The residuals from these regressions are our new measure of smart development. With a minimum of ecological footprint one has to achieve a maximum of democracy, or economic growth, or gender equality, or human development, or research and development, or social cohesion, and/or the combination of all of them. We then look at the drivers and bottlenecks of smart development. We use standard comparative cross-national development accounting data which operationalize standard econometric drivers of economic growth, and compare their weight in explaining smart development with the results for the clash of civilization models, political integration theories, feminist theories, migration theories, and peace research approaches to global development. We also analyze the possible explanatory weight of sociological dependency and world systems theories and later globalization critical research, and also do not overlook a possible effect on the smart development - the 'small is beautiful paradigm' in the tradition of Schumacher. A full list of dependent and independent variables appear in Table 1. 
Table 1

The Combined Six Components, Measuring Development, and the Overall Indicators, Combining 26 Variables

\begin{tabular}{|c|c|c|}
\hline Democracy & 1 & Combined Failed States Index \\
\hline Democracy & 2 & Civil and Political Liberties violations \\
\hline Democracy & 3 & Corruption avoidance measure \\
\hline Democracy & 4 & Democracy measure \\
\hline Democracy & 5 & Global tolerance index \\
\hline Democracy & 6 & Rule of law \\
\hline Economic growth & 7 & Crisis Performance Factor \\
\hline Economic growth & 8 & Economic growth IMF prediction growth rate in 2009 \\
\hline Economic growth & 9 & Economic growth IMF prediction growth rate in 2010 \\
\hline Economic growth & 10 & Economic growth in real terms pc. per annum, 1990-2005 \\
\hline Gender equality & 11 & Closing economic gender gap \\
\hline Gender equality & 12 & Closing educational gender gap \\
\hline Gender equality & 13 & Closing health and survival gender gap \\
\hline Gender equality & 14 & Closing of global gender gap overall score 2009 \\
\hline Gender equality & 15 & Closing political gender gap \\
\hline Gender equality & 16 & Gender empowerment index value \\
\hline Human development & 17 & Infant mortality 2005 \\
\hline Human development & 18 & Female survival probability of surviving to age 65 \\
\hline Human development & 19 & Human development index (HDI) value 2004 \\
\hline Human development & 20 & Life Expectancy (years) \\
\hline Human development & 21 & Life Satisfaction (0-10) \\
\hline $\mathrm{R} \& \mathrm{D}$ & 22 & Country share in top world 500 Universities \\
\hline $\mathrm{R} \& \mathrm{D}$ & 23 & Per capita world class universities \\
\hline $\mathrm{R} \& \mathrm{D}$ & 24 & Tertiary enrollment \\
\hline Social cohesion & 25 & Quintile share income difference between richest and poorest $20 \%$ \\
\hline Social cohesion & 26 & Unemployment rate \\
\hline $\begin{array}{l}\text { Nonparametric } 26 \text { equal } \\
\text { weights }\end{array}$ & 27 & Overall 26 development index \\
\hline $\begin{array}{l}\text { Nonparametric, weighting } \\
\text { each dimension equally }\end{array}$ & 28 & Overall 26 development index, based on six dimensions \\
\hline
\end{tabular}

The choice of a country to be included in the final analysis (175 countries) was determined by the availability of a fairly good data series for these independent variables (if not mentioned otherwise, UNDP data around 2005). In the final regressions, we applied the 'list-wise deletion of missing values' routine. The statistical design of our study is thus based on the usual OLS standard regression analysis of the 'kitchen sink type' (Durlauf et al., 2008; Hertz, Hebert, and Landon, 1994) of economic growth and 
economic, social and political performance in the research tradition of Barro (2003). ${ }^{[8]}$ Surveying the vast econometric literature on the subject of the possible drivers and bottlenecks of the EU-2020 process and overall development performance of a given country, one indeed finds support for the inclusion of geographic and demographic variables in the comparative analysis of development success or failure. Our list thus corresponds to the international research standard praxis in the discipline of general development accounting (Barro and Sala-i-Martin, 2003; Dixon, 1987; Dixon and Moon, 1986, 1989; Durlauf et al., 2008; Fain, 1997; Fosu, 2009, 2010a, 2010b, 2010c; Moon and Dixon, 1992; Shandra, 2007a, 2007b; Shandra et al., 2009; Tausch and Prager, 1993).

Knight and Rosa (2011) compared the ecological footprint per capita and average life satisfaction (as a measure of subjective well-being). Based on maximum likelihood estimations, they tested the effects of climate, political, economic, and social factors on environmental efficiency of well-being (EEWB) with a sample of 105 countries. Knight and Rosa found a negative quadratic effect of economic development on EEWB, a negative effect of income inequality, and a positive effect of social capital. ${ }^{[9]}$

Compared to (Knight and Rosa, 2011), we include globalization-oriented variables as well, and not just levels of GDP, winters, social trust, democracy, inequality, and Latin America, the former USSR, Africa, and Asia as dummy variables. There is a wide and well-established research tradition in international comparative sociology to include globalization-related drivers of environmental decay (Jorgenson, 2008, 2009a, 2009b, $2009 \mathrm{c}, 2009 \mathrm{~d})$. To exclude such variables and to introduce instead four geographically determined dummy variables does not increase the theoretical and predictive power of analysis.

The statistical design of our study is based on the usual SPSS-PAWS XVIII ${ }^{[10]}$ ordinary least square standard regression of the kitchen sink type. The term was re-introduced in more recent standard social science journal vocabulary in Laver and Shepsle (1999). Prior stepwise regression procedures selected the significant among the total list of 26 available predictors. Among the many international studies that apply to such a research design, we find Hertz, Hebert, and Landon (1994).

\section{Empirical Results}

\section{The Relationship between HLYE, EFPC and Development Performance}

Since our article does not feature primarily the ecological footprint, but relies on a variety of measures of smart development which are mathematically derived from the logic of the Happy Planet Index (see also Ng, 2008a and 2008b; Veenhoven, 1996), it

\footnotetext{
8 To our knowledge, the term 'kitchen sink regression,' was re-introduced in more recent standard social science journal vocabulary in Laver and Shepsle, (1999).

9 http://www.worldvaluessurvey.org/

$10 \mathrm{http}: / / \mathrm{www}-01$. ibm.com/software/analytics/spss/products/statistics/
} 
suffices to say here that the ecological footprint (g ha /cap), ${ }^{[11]}$ is indeed a one-catchallindicator of ecological strain caused by human activity (see also Dietz et al., 2007 and 2009). The footprint is a measure of the amount of land required to provide for all their resource requirements plus the amount of vegetated land required to sequester (absorb) all their $\mathrm{CO}_{2}$ emissions and the $\mathrm{CO}_{2}$ emissions embodied in the products individuals consume. This figure is expressed in units of global hectares. In 2005, the per capita footprint for the rich OECD nations was 6.0 global hectares. ${ }^{[12]}$ The other variables are then compared to the footprint which was used by a society to achieve a given standard of democracy, economic growth, gender equality, human development, research and development, and social cohesion. The Happy Planet Index Organization measures the Happy Planet Index on the basis of the global life satisfaction (Happy Life Years) which have to be maximized in relationship to the ecological price of happiness, the ecological footprint.

It is then very tempting to calculate - in a Schumacherian tradition - the environmental price of different development processes like democracy, economic growth, gender equality, human development, research and development, and social cohesion. The Happy Planet Organization calculates the HPI in the following way:

(1) $H P I_{i}=\left(\left(H L Y E_{i}\right) /\left(E F P C_{i}+\alpha\right)\right) \times \beta$

where Happy Life Years (HLYE) is obtained as both the product of life expectancy (LE) and the average life satisfaction (LS) index. In its currently used formula, the Happy Planet Organization adds a constant $(\alpha)$ to the ecological footprint. The result of the division: [Happy Life Years divided by Ecological Footprint plus the constant (a)] is then multiplied by another, equally arbitrarily chosen constant $(\beta)$ to normalize the efficiency index. In the Happy Planet Organization formula, the constants have the following numerical values: $(\breve{G})=3.35$ and $(\beta)=6.42$.

The highest global HPI score is that of Costa Rica (76.1 out of 100). Of the 10 best performing countries of the world, nine are in Latin America. ${ }^{[13]}$ Goldstein (1985) empirically developed the idea that basic human needs indicators - like life expectancy - are a non-linear function of development levels; this has been widely received in the social science literature. ${ }^{[14]}$ The neglect of such a basic non-linear function ${ }^{[15]}$ is a major shortcoming of the currently used Happy Planet Index calculation. The global public health research tradition, too, produced massive evidence on the cross-national determinants

\footnotetext{
$11 \mathrm{http}: / / \mathrm{www}$. footprintnetwork.org/en/index.php/GFN/

$12 \mathrm{http}: / /$ www.happyplanetindex.org/

$13 \mathrm{http} / / / \mathrm{www} \cdot h a p p y p l a n e t i n d e x . o r g /$

14 See Afxentiou (1990a, 1990b), Anand and Ravillion (1993), Anson (1988, 1991), Cheng (1989), Dixon (1987), Dixon and Moon (1986, 1989), Fosu (2009, 2010a, 2010b, 2010c), Kakwani (1993, 1995), Khan (1991), King (1998), Knight and Rosa,, (2011), Mazumdar (1996, 2000), Moon and Dixon,, (1992), Newman and Thomson (1989), Rudra (2009), and Tausch and Prager (1993).

15 The most often encountered formulation in the literature is a double logarithmic expression, based on the natural logarithm of development level/energy consumption and its square.
} 
of life expectancy and other life quality variables (Wilkinson, 1992; Wilkinson and Picket, 2006; Tausch, 2010). This growing methodological convergence of the social sciences, geography and earth sciences, and public health research on the predictors of life quality at different stages of development should be taken into account in this article (Fain, et al. 1997; Mostafa, 2010a and 2010b; Mostafa and Nataraajan, 2009; Shandra, 2007a, 2007b, Shandra, Leckband, McKinney and London, 2009).

We investigated the non-linear trade-offs between ecological footprint and the combined UNDP type indices for six dimensions of development. The results are reported in Table 2.

Table 2

The Non-linear Relationship between Happy Life Years and Ecological Footprint, n=140 Countries in 2005.

\begin{tabular}{l|l|l}
\hline Variable & Coefficient & Std Error \\
\hline $\begin{array}{l}\text { Ecological Footprint per } \\
\text { capita }\end{array}$ & $10.541 \mathrm{a}$ & 1.313 \\
\hline $\begin{array}{l}\text { Ecological Footprint per } \\
\text { capita^2 }\end{array}$ & $-0.677 \mathrm{a}$ & 0.147 \\
\hline Constant & $19.631 \mathrm{a}$ & 2.246 \\
\hline $\mathrm{N}=$ & 140 & \\
\hline Adj. $\mathrm{R}^{\wedge} 2=$ & 0.541 & \\
\hline F-test $=$ & 83.081 & \\
\hline p-value $=$ & 0.000 & \\
\hline
\end{tabular}

Note: significant at $<1 \%(a), 1-5 \%(b), 6-10 \%(c)$.

Graph 1 depicts the trade-off between ecological footprint and happy life years; the (standardized) residuals in our graph are a reformulated Happy Planet Index: 
Graph 1

The Non-linear Relationship between Happy Life Years (HLYE, Vertical) and Ecological Footprint (horizontal), n=140 Countries in 2005.

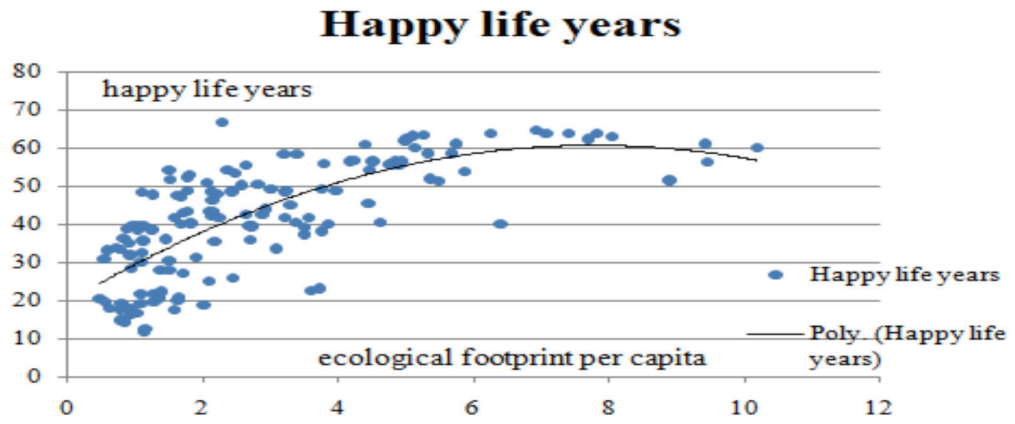

Appendix Graphs 2a-2h show the trade-off between ecological footprint and smart development, measured for the various dimensions (democracy, economic growth, gender equality, human development, research and development, social cohesion, and the two differently combined overall measurement scales). Only the scatterplot for ecological footprint and social cohesion suggests a weaker relationship; all the other relationships are considerable. The overall development performance, democracy, gender equality, human development, research and development are a clear non-linear, inverted U-shaped function of ecological footprint per capita, while economic growth and also social cohesion first decrease and then increase with rising levels of ecological footprint per capita.

The hitherto existing calculations of the HPI, ${ }^{[16]}$ provided by the Happy Planet Organization, are merely based on simple arithmetical principles. Following Heintz, 1972 we propose as an alternative method a residual method and calculate our smart development indicators as the standardized residuals from Appendix Graph 2. The standardized residual values are computed as observed minus predicted development outcomes divided by the square root of the residual mean square (see Appendix, Table 1 and 2):

(2) $S D P_{i}=\left(H L Y E_{i}-H L Y \hat{E}_{i}\right) / \hat{\sigma}$

High positive outliers imply a very high smart development performance, while countries below the trend line are the countries with a low smart development performance. Having established a residual-based smart Development Indicator family, we now can look at the cross-national determinants of smart development performance.

16 We refer our readers to the very comprehensive Yale/Columbia environmental data series available at http://sedac. ciesin.columbia.edu/es/esi/ and http://epi.yale.edu/Home. The new 'grammar' of the global footprint discourse can be found at http://www.footprintnetwork.org/en/index.php/GFN/page/glossary/ . 


\section{Results on the Drivers and Bottlenecks of Smart Development}

The image of social realities suggested upon a first inspection of smart development performance values around the globe would point to a Friedrich August Hayek vision (Hayek, 1945, 1989) of markets, inequality and a free society interacting with one another. There should be no blocks against inequalities in the name of whatever social justice, explaining then the phenomenal success of the unequal Latin American societies on the parameters of smart development (see the global rankings of smart development in Appendix Table 3). At the same time, the high-equality performers in global society (quintile share of less than 5.0) with a relatively high per-capita income are at the same time bad performers on the new smart development scales. Notably enough, several of these countries are members of the European Union and are traditional developed western welfare states. This very first glance at the data would suggest a complete turn-around from the European social model (Tausch and Ghymers, 2006) in favor of a high-inequality, open to globalization 'Latin American model' or a Philippine model as the best way to achieve a good smart development performance. However, such a first glance overlooks the massive available evidence about world economic openness and the failure of smart development.

As to the multivariate analysis, first preliminary stepwise regression procedures with mean substitution of missing variables revealed a re-current pattern of the importance and predictive capability robustness of the chosen variables among the 26 independent variables with a theoretically well-plausible greater and significant effect on the dependent variables (the six component indicators of development and the overall development performance indicators). The final results were achieved by forward multiple regression based on a list-wise deletion of missing values, and based exclusively on the significant predictors from the prior preliminary stepwise regressions. We first present results of our multiple regression analyses in Table 3. 
Table 3

The Significant Drivers and Bottlenecks of Smart Development

\begin{tabular}{|c|c|c|c|}
\hline Independent Variable & Dependent variable & Beta & $\begin{array}{l}\text { error } \\
\text { prob. }\end{array}$ \\
\hline $\begin{array}{l}\% \text { women in government, all levels (feminist theory, } \\
\text { stressing the need to feminize structures of government) }\end{array}$ & $\begin{array}{l}\text { Overall smart development } \\
\text { index, based on } 26 \text { variables, } \\
\text { weighted equally }\end{array}$ & 0.185 & 0.045 \\
\hline $\begin{array}{l}\% \text { women in government, all levels (feminist theory, } \\
\text { stressing the need to feminize structures of government) }\end{array}$ & Smart democracy & 0.196 & 0.007 \\
\hline $\begin{array}{l}\% \text { women in government, all levels (feminist theory, } \\
\text { stressing the need to feminize structures of government) }\end{array}$ & Smart gender justice & 0.300 & 0.001 \\
\hline$\%$ world population (Amin's five monopolies of power) & Smart human development & 0.152 & 0.061 \\
\hline$\%$ world population (Amin's five monopolies of power) & Happy Life Years & 0.161 & 0.060 \\
\hline$\%$ world population (Amin's five monopolies of power) & Smart economic growth & 0.261 & 0.002 \\
\hline $\begin{array}{l}2000 \text { Economic Freedom Score (its absence is } \\
\text { explained either by Amin's critique of rent-seeking } \\
\text { seeking in the periphery or conventional neo-liberal } \\
\text { theories of economic growth) }\end{array}$ & $\begin{array}{l}\text { Overall smart development } \\
\text { index, based on } 26 \text { variables, } \\
\text { weighted equally }\end{array}$ & 0.336 & 0.002 \\
\hline $\begin{array}{l}2000 \text { Economic Freedom Score (its absence is } \\
\text { explained either by Amin's critique of rent-seeking } \\
\text { seeking in the periphery or conventional neo-liberal } \\
\text { theories of economic growth) }\end{array}$ & $\begin{array}{l}\text { Overall smart development } \\
\text { index, based on } 26 \text { variables, } \\
\text { weighted equally }\end{array}$ & 0.402 & 0.000 \\
\hline $\begin{array}{l}2000 \text { Economic Freedom Score (its absence is } \\
\text { explained either by Amin's critique of rent-seeking } \\
\text { seeking in the periphery or conventional neo-liberal } \\
\text { theories of economic growth) }\end{array}$ & Smart democracy & 0.457 & 0.000 \\
\hline $\begin{array}{l}\text { Absolute latitude (Andre Gunder Frank's 'Re-Orient' } \\
\text { model) }\end{array}$ & Smart economic growth & -0.234 & 0.006 \\
\hline $\begin{array}{l}\text { Annual population growth rate, 1975-2005 (\%) (Paul } \\
\text { Israel Singer's dependency theory) }\end{array}$ & Smart R\&D & -0.253 & 0.007 \\
\hline $\begin{array}{l}\text { Annual population growth rate, 1975-2005 (\%) (Paul } \\
\text { Israel Singer's dependency theory) }\end{array}$ & Smart social cohesion & -0.248 & 0.006 \\
\hline $\begin{array}{l}\text { Immigration - Share of population } 2005(\%) \text { (Amin's } \\
\text { theory about the role of migration) }\end{array}$ & Smart democracy & -0.348 & 0.000 \\
\hline $\begin{array}{l}\text { Military expenditures per GDP (quantitative } \\
\text { dependency and peace research approaches) }\end{array}$ & Happy Life Years & -0.245 & 0.004 \\
\hline $\begin{array}{l}\text { Military expenditures per GDP (quantitative } \\
\text { dependency and peace research approaches) }\end{array}$ & Smart gender justice & -0.204 & 0.018 \\
\hline $\begin{array}{l}\text { Military expenditures per GDP (quantitative } \\
\text { dependency and peace research approaches) }\end{array}$ & $\begin{array}{l}\text { Overall smart development } \\
\text { index, based on } 26 \text { variables, } \\
\text { weighted equally }\end{array}$ & -0.191 & 0.021 \\
\hline $\begin{array}{l}\text { Military expenditures per GDP (quantitative } \\
\text { dependency and peace research approaches) }\end{array}$ & $\begin{array}{l}\text { Overall smart development } \\
\text { index, based on } 26 \text { variables, } \\
\text { weighted equally }\end{array}$ & -0.166 & 0.074 \\
\hline $\begin{array}{l}\text { Military personnel rate ln (quantitative dependency and } \\
\text { peace research approaches) }\end{array}$ & Smart democracy & -0.221 & 0.002 \\
\hline
\end{tabular}




\begin{tabular}{|c|c|c|c|}
\hline Independent Variable & Dependent variable & Beta & $\begin{array}{l}\text { error } \\
\text { prob. }\end{array}$ \\
\hline $\begin{array}{l}\text { MNC outward investments (stock) per GDP } \\
\text { (Bornschier's dependency theory, stressing the } \\
\text { importance of MNC headquarter status in international } \\
\text { society) }\end{array}$ & Smart R\&D & 0.479 & 0.000 \\
\hline $\begin{array}{l}\text { Muslim population share per total population (Amin's } \\
\text { critique of Islamism, implicitly expecting a negative } \\
\text { trade-off with development performance versus Andre } \\
\text { Gunder Frank's 'Re-Orient' model, expecting a transfer } \\
\text { of growth and productive activities to the global East } \\
\text { and South) }\end{array}$ & Smart gender justice & -0.396 & 0.000 \\
\hline $\begin{array}{l}\text { Muslim population share per total population (Amin's } \\
\text { critique of Islamism, implicitly expecting a negative } \\
\text { trade-off with development performance versus Andre } \\
\text { Gunder Frank's 'Re-Orient' model, expecting a transfer } \\
\text { of growth and productive activities to the global East } \\
\text { and South) }\end{array}$ & Smart economic growth & 0.313 & 0.000 \\
\hline $\begin{array}{l}\text { Openness-Index, } 1990 \text { (export-share per GDP + import- } \\
\text { share per GDP) (Amin's conception of the role of the } \\
\text { peripheries) }\end{array}$ & Smart R\&D & -0.552 & 0.000 \\
\hline $\begin{array}{l}\text { Openness-Index, } 1990 \text { (export-share per GDP + import- } \\
\text { share per GDP) (Amin's conception of the role of the } \\
\text { peripheries) }\end{array}$ & $\begin{array}{l}\text { Overall smart development } \\
\text { index, based on } 26 \text { variables, } \\
\text { weighted equally }\end{array}$ & -0.222 & 0.019 \\
\hline $\begin{array}{l}\text { Openness-Index, } 1990 \text { (export-share per GDP + import- } \\
\text { share per GDP) (Amin's conception of the role of the } \\
\text { peripheries) }\end{array}$ & $\begin{array}{l}\text { Overall smart development } \\
\text { index, based on } 26 \text { variables, } \\
\text { weighted equally }\end{array}$ & -0.170 & 0.048 \\
\hline $\begin{array}{l}\text { Population density (José Carlos Mariategui's } \\
\text { dependency theory) }\end{array}$ & $\begin{array}{l}\text { Overall smart development } \\
\text { index, based on } 26 \text { variables, } \\
\text { weighted equally }\end{array}$ & 0.214 & 0.010 \\
\hline $\begin{array}{l}\text { Public education expenditure per GNP (human } \\
\text { capital approaches in the tradition of the UNDP } \\
\text { versus Kalecki/Steindl paradigm versus neo-liberal } \\
\text { approaches, featuring a 'crowding out' phenomenon) }\end{array}$ & Smart social cohesion & -0.270 & 0.003 \\
\hline $\begin{array}{l}\text { Public education expenditure per GNP (human } \\
\text { capital approaches in the tradition of the UNDP } \\
\text { versus Kalecki/Steindl paradigm versus neo-liberal } \\
\text { approaches, featuring a 'crowding out' phenomenon) }\end{array}$ & Smart human development & -0.196 & 0.024 \\
\hline $\begin{array}{l}\text { Public education expenditure per GNP (human } \\
\text { capital approaches in the tradition of the UNDP } \\
\text { versus Kalecki/Steindl paradigm versus neo-liberal } \\
\text { approaches, featuring a 'crowding out' phenomenon) }\end{array}$ & Smart R\&D & 0.235 & 0.010 \\
\hline $\begin{array}{l}\text { UNDP education index (human capital approaches } \\
\text { in the tradition of the UNDP versus Kalecki/Steindl } \\
\text { paradigm) }\end{array}$ & $\begin{array}{l}\text { Overall smart development } \\
\text { index, based on } 26 \text { variables, } \\
\text { weighted equally }\end{array}$ & 0.198 & 0.036 \\
\hline $\begin{array}{l}\text { UNDP education index (human capital approaches } \\
\text { in the tradition of the UNDP versus Kalecki/Steindl } \\
\text { paradigm) }\end{array}$ & Smart human development & 0.478 & 0.000 \\
\hline
\end{tabular}




\begin{tabular}{|c|c|c|c|}
\hline Independent Variable & Dependent variable & Beta & $\begin{array}{l}\text { error } \\
\text { prob. }\end{array}$ \\
\hline $\begin{array}{l}\text { Worker remittance inflows as \% of GDP (conventional } \\
\text { center-periphery models about the negative } \\
\text { consequences of the brain drain versus new migration } \\
\text { theories, underlining the positive effects of worker } \\
\text { remittances on migration sending countries) }\end{array}$ & Smart economic growth & -0.262 & 0.002 \\
\hline $\begin{array}{l}\text { Worker remittance inflows as \% of GDP (conventional } \\
\text { center-periphery models about the negative } \\
\text { consequences of the brain drain versus new migration } \\
\text { theories, underlining the positive effects of worker } \\
\text { remittances on migration sending countries) }\end{array}$ & $\begin{array}{l}\text { Overall smart development } \\
\text { index, based on } 26 \text { variables, } \\
\text { weighted equally }\end{array}$ & 0.177 & 0.064 \\
\hline $\begin{array}{l}\text { Worker remittance inflows as \% of GDP (conventional } \\
\text { center-periphery models about the negative } \\
\text { consequences of the brain drain versus new migration } \\
\text { theories, underlining the positive effects of worker } \\
\text { remittances on migration sending countries) }\end{array}$ & $\begin{array}{l}\text { Overall smart development } \\
\text { index, based on } 26 \text { variables, } \\
\text { weighted equally }\end{array}$ & 0.208 & 0.016 \\
\hline $\begin{array}{l}\text { Worker remittance inflows as \% of GDP (conventional } \\
\text { center-periphery models about the negative } \\
\text { consequences of the brain drain versus new migration } \\
\text { theories, underlining the positive effects of worker } \\
\text { remittances on migration sending countries) }\end{array}$ & Smart R\&D & 0.229 & 0.017 \\
\hline $\begin{array}{l}\text { Worker remittance inflows as \% of GDP (conventional } \\
\text { center-periphery models about the negative } \\
\text { consequences of the brain drain versus new migration } \\
\text { theories, underlining the positive effects of worker } \\
\text { remittances on migration sending countries) }\end{array}$ & Smart gender justice & 0.241 & 0.007 \\
\hline $\begin{array}{l}\text { Worker remittance inflows as \% of GDP (conventional } \\
\text { center-periphery models about the negative } \\
\text { consequences of the brain drain versus new migration } \\
\text { theories, underlining the positive effects of worker } \\
\text { remittances on migration sending countries) }\end{array}$ & Happy Life Years & 0.288 & 0.002 \\
\hline $\begin{array}{l}\text { Worker remittance inflows as \% of GDP (conventional } \\
\text { center-periphery models about the negative } \\
\text { consequences of the brain drain versus new migration } \\
\text { theories, underlining the positive effects of worker } \\
\text { remittances on migration sending countries) }\end{array}$ & Smart human development & 0.352 & 0.000 \\
\hline $\begin{array}{l}\text { Years of membership in the EU, } 2010 \text { (Amin's theory } \\
\text { about the importance of European integration as a } \\
\text { counterweight to US dominance in the world system) }\end{array}$ & Smart democracy & 0.183 & 0.006 \\
\hline
\end{tabular}

The following independent variables wield only good and positive effects on smart development:

- \% women in government, all levels (feminist theory; three effects positive; zero effects negative)

- \% world population (Amin's five monopolies of power; three effects positive; zero effects negative)

- Economic Freedom Score (Amin's critique of rent-seeking; three effects positive; zero effects negative)

- MNC outward investments (stock) per GDP (Bornschier's dependency 
theory; one effect positive; zero effects negative)

- population density (José Carlos Mariategui's dependency theory; one effect positive; zero effects negative)

- UNDP education index (Steindl/Kalecki-paradigm; two effects positive; zero effects negative)

- Years of membership in the EU (Amin's theory about the role of integration; one effect positive; zero effects negative)

The following predictors wielded only negative consequences on smart development:

- Absolute latitude (Andre Gunder Frank's 'Re-Orient' model; zero effects positive; one effect negative)

- Annual population growth rate (\%) (Paul Israel Singer's dependency theory; zero effects positive; two effects negative)

- Immigration share of total population (\%) (Amin's theory about the role of migration; zero effects positive; one effect negative)

- military expenditures per GDP (dependency and peace research approaches; zero effects positive; four effects negative)

- military personnel rate (dependency and peace research approaches; zero effects positive; one effect negative)

- Openness-Index (export-share per GDP minus import-share per GDP) (Amin's conception of the role of the peripheries; zero effects positive, three effects negative)

The following variables wielded mixed results:

- worker remittance inflows as \% of GDP (six effects positive; one effect negative)

- Muslim population shares (one effect positive; one effect negative)

- public education expenditure per GNP (one effect positive; two effects negative)

The following predictors seem to wield an overwhelming power:

- workers remittances (six positive effects);

- feminization of power structure (three positive effects)

- share of world population (three positive effects)

- economic freedom (three positive effects)

- world economic openness index (three negative effects),

- military expenditures (four negative effects).

In the following, we will present the results of our research. Table 4 shows the significant drivers and bottlenecks of Happy Planet performance, i.e. happy life years in relationship to the ecological footprint of a particular society used. The z-standardized residuals from Graph 2 are well-explained; our equation is based on 103 countries with complete data. It explains $29 \%$ of total variance; the F-value for the entire equation is 9.339, and the error probability is 0.000 . The constant is -124.628 and is significant. 
There is a clear Kuznets curve at work (see also Stern, 2004). But the shape of the curve contradicts much of the earlier debate on the subject: with rising per capita incomes, problem solving capacities first increase and then decrease. The larger states in the world system, having a larger share of global population, are much better able to achieve a good happy-life-years' performance at relatively low ecological costs, measured in ecological footprints than smaller nations. This clearly contradicts the small is beautiful philosophy in the tradition of Kohr and Schumacher. Military expenditures are a clear additional burden on an ecologically viable happy planet performance, while those societies dependent on worker remittances clearly manage to perform better on this scale than other societies around the globe.

Table 4

The Drivers and Bottlenecks of Happy Planet Performance

\begin{tabular}{l|l|l|l}
\hline Independent Variable & B & Std error & Beta \\
\hline Constant & $-124.628 \mathrm{a}$ & 42.647 & \\
\hline$\%$ world population & $0.596 \mathrm{c}$ & 0.313 & 0.161 \\
\hline In GDP per capita & $26.062 \mathrm{~b}$ & 10.069 & 3.136 \\
\hline In GDP per capita ^2 & $-1.309 \mathrm{~b}$ & 0.584 & -2.731 \\
\hline Military expenditures per GDP & $-1.098 \mathrm{a}$ & 0.376 & -0.245 \\
\hline Worker remittance inflows as \% of GDP & $0.420 \mathrm{a}$ & 0.133 & 0.288 \\
\hline Statistical properties of the equation & adj R^2 & $\mathrm{df}$ & $\mathrm{F}$ \\
\hline Note: significant at <1\%(a), 1-5\%(b), 6-10\%(c) & 29.000 & 102 & 9.339 \\
\hline
\end{tabular}

In a similar fashion, we can establish in Table 5 that in the 101 countries with complete data, smart overall development, as defined in Graph $2 \mathrm{a}$ of this work, is explained up to $37 \%$ by our model. The F-test for the entire equation is 9.392 , the error probability is 0.000 . The constant is -2.486 and is significant. The ten countries of the world system best combining the performance on our 26 development indicators and avoiding an ecological footprint at the same time are the Philippines, Sri Lanka, Costa Rica, Sweden, Jamaica, the Dominican Republic, Finland, Peru, the Netherlands, and Trinidad and Tobago. The ten worst performers on this scale are Sudan, Bosnia and Herzegovina, the Central African Republic, the United Arab Emirates, Niger, Kuwait, Chad, Zimbabwe, Burundi, and Hong Kong, China (SAR). Feminism in power, economic freedom, population density, the UNDP education index as well as the receipt of worker remittances, all significantly contribute towards a smart overall development, while high military expenditures and a high world economic openness are bottlenecks for smart overall development. 
Table 5

Drivers and Bottlenecks of Smart Overall Development

\begin{tabular}{l|l|l|l}
\hline Independent Variable & B & Std error & Beta \\
\hline Constant & $-2.486 \mathrm{a}$ & 0.533 & \\
\hline \% women in government. all levels & $0.025 \mathrm{~b}$ & 0.012 & 0.185 \\
\hline 2000 Economic Freedom Score & $0.031 \mathrm{a}$ & 0.010 & 0.336 \\
\hline military expenditures per GDP & $-0.076 \mathrm{~b}$ & 0.032 & -0.191 \\
\hline $\begin{array}{l}\text { Openness-Index. 1990 (export-share + import-share per } \\
\text { GDP) }\end{array}$ & $-0.004 \mathrm{~b}$ & 0.002 & -0.170 \\
\hline Population density & $0.002 \mathrm{a}$ & 0.001 & 0.214 \\
\hline UNDP education index & $0.945 \mathrm{~b}$ & 0.445 & 0.198 \\
\hline Worker remittance inflows as \% of GDP & $0.027 \mathrm{~b}$ & 0.011 & 0.208 \\
\hline Statistical properties of the equation & $\mathrm{adj} \mathrm{R}^{\wedge} 2$ & $\mathrm{df}$ & $\mathrm{F}$ \\
\hline Note: significant at <1\%(a), 1-5\%(b), 6-10\%(c) & 37.000 & 100 & 9.392 \\
\hline
\end{tabular}

Also it emerges that the results about the drivers of overall smart development performance are similar to the ones reported in Table 6, if we calculate the overall development performance by weighting equally its six component indices and only then calculating the overall final country performance score, and not, unlike in Table 5 , being based on the sum of the equally weighted 26 original component indices (as to the trade-off with ecological footprint, see Appendix Graph 2b). Economic freedom and received worker remittances per GDP again emerge as the drivers of smart development (Table 6), while the bottlenecks of smart overall development performance are again military expenditures per GDP and world economic openness. This time, the adjusted $\mathrm{R}^{\wedge} 2$ is $19 \%$, and the equation is based on 102 countries with complete data. The F-test for the entire equation is 6.908 , and the equation is significant at the 0.000 -level. The constant is -1.469 and is significant.

Table 6

Drivers and Bottlenecks of Smart Overall Development, Based on an Index which Weighs the Six Dimensions Equally

\begin{tabular}{l|l|l|l}
\hline Independent Variable & B & Std error & Beta \\
\hline Constant & $-1.469 \mathrm{a}$ & 0.536 & \\
\hline 2000 Economic Freedom Score & $0.035 \mathrm{a}$ & 0.008 & 0.402 \\
\hline Military expenditures per GDP & $-0.061 \mathrm{c}$ & 0.034 & -0.166 \\
\hline $\begin{array}{l}\text { Openness-Index. } 1990 \text { (export-share + import-share per } \\
\text { GDP) }\end{array}$ & $-0.005 \mathrm{~b}$ & 0.002 & -0.222 \\
\hline Worker remittance inflows as \% of GDP & $0.021 \mathrm{c}$ & 0.011 & 0.177 \\
\hline Statistical properties of the equation & adj R^2 & Df & F \\
\hline Note: significant at $<1 \%(a), 1-5 \%(b), 6-10 \%(c)$ & 19.000 & 101 & 6.908 \\
\hline
\end{tabular}


Table 7 is an invitation to consider the drivers and bottlenecks of smart democracy (see also Appendix Graph 2c). The ten smartest democracies of our globe are Costa Rica, the Netherlands, Jamaica, Chile, Sweden, India, Benin, Madagascar, Finland, and Germany; these are the countries of the world system that best combine democratic performance and avoid an ecological footprint. The worst performers are Sudan, Belarus, Kazakhstan, Kuwait, the United Arab Emirates, Uzbekistan, Lebanon, Hong Kong, China (SAR), Azerbaijan, and Myanmar. The adjusted $\mathrm{R}^{\wedge} 2$ of our equation is $48.6 \%$, and the F-value for the entire equation is 25.743 with the error $\mathrm{p}$ for the equation being 0.000 . It is based on 132 countries with complete data. The drivers of smart democracy are feminized structures of government, economic freedom, and years of membership in the European Union. The significant bottlenecks of smart democracy are high military personnel ratios and a high share of immigrant population. The constant of our equation is -2.037 , and it is significant.

Table 7

Drivers and Bottlenecks of Smart Democracy

\begin{tabular}{l|l|l|l}
\hline Independent Variable & B & Std error & Beta \\
\hline Constant & $-2.037 \mathrm{a}$ & 0.409 & \\
\hline$\%$ women in government. all levels & $0.029 \mathrm{a}$ & 0.011 & 0.196 \\
\hline 2000 Economic Freedom Score & $0.041 \mathrm{a}$ & 0.007 & 0.457 \\
\hline Military personnel rate ln (MPR+1) & $-0.334 \mathrm{a}$ & 0.105 & -0.221 \\
\hline Immigration - Share of population 2005 (\%) & $-0.031 \mathrm{a}$ & 0.007 & -0.348 \\
\hline Years of membership in the EU. 2010 & $0.014 \mathrm{a}$ & 0.005 & 0.183 \\
\hline Statistical properties of the equation & adj R^2 & $\mathrm{df}$ & $\mathrm{F}$ \\
\hline Note: significant at <1\%(a), 1-5\%(b), 6-10\%(c) & 48.600 & 131 & 25.743 \\
\hline
\end{tabular}

Our next Table, Table 8, analyses the drivers and bottlenecks of smart economic growth combining high economic growth with low rates of ecological footprint per capita (see also Appendix Graph 2d). The IMF data for economic growth in 2010 as well as the Happy Planet Organization data on ecological footprint suggest that the 10 best performers were China, Azerbaijan, Botswana, Uzbekistan, Congo (Democratic Republic of the), Bhutan, Sudan, Mongolia, Ethiopia, and Lebanon, while the worst performers with the worst cocktail of slow economic growth in relation to their ecological footprint per capita were Zimbabwe, Moldova, Lithuania, Latvia, Ukraine, Jamaica, Haiti, Armenia, Tajikistan, and Madagascar. Our equation about smart growth is based on 111 countries with complete data; the $\mathrm{R}^{\wedge} 2$ is $25.2 \%$, the F-value is 10.243 , and the error probability of the entire equation is 0.000 . The constant is 0.195 , and it is not significant. Population size in relation to the global population as well as Muslim population share per total population are the significant drivers of smart development in the global system today, while absolute latitude (i.e. countries in the far North and South of the world system) as well as nations depending on worker remittances are the bottlenecks of smart growth today. This again suggests the tectonic shifts in the 
geographical structures of global growth today, away from the countries of the North Atlantic arena towards the nations of the Indian and Pacific Oceans. Those shifts also thwart the smart growth efforts of the countries exporting their workforce to the hitherto existing centers of the global economy.

Table 8

Drivers and Bottlenecks of Smart Economic Growth (2010)

\begin{tabular}{l|l|l|l}
\hline Independent Variable & B & Std error & Beta \\
\hline Constant & 0.195 & 0.178 & \\
\hline$\%$ world population & $0.099 \mathrm{a}$ & 0.031 & 0.261 \\
\hline Absolute latitude & $-0.013 \mathrm{a}$ & 0.005 & -0.234 \\
\hline Worker remittance inflows as \% of GDP & $-0.035 \mathrm{a}$ & 0.011 & -0.262 \\
\hline Muslim population share per total population & $0.009 \mathrm{a}$ & 0.002 & 0.313 \\
\hline Statistical properties of the equation & adj R^2 & df & $\mathrm{F}$ \\
\hline Note: significant at $<1 \%(\mathrm{a}), 1-5 \%(\mathrm{~b}), 6-10 \%(\mathrm{c})$ & 25.200 & 110 & 10.243 \\
\hline
\end{tabular}

Table 9 of our study analyzes the drivers and bottlenecks of smart gender justice. We are comparing the given amount of gender equality in a society with the amount of resources (ecological footprint) needed to sustain it (see Appendix Graph 2e). The global best performers on this equation, that is, those in achieving a maximum of gender justice with a minimum of ecological footprint, are the Philippines, South Africa, Finland, Norway, Mozambique, Sweden, Iceland, Kyrgyzstan, Sri Lanka, and Uganda. The worst balance sheet on this item of combining 'lilac' gender policies and 'green' issues are Yemen, Saudi Arabia, the United Arab Emirates, Turkey, Pakistan, Chad, Iran, Kuwait, Korea (Republic of), and Egypt. Our equation, based on the 93 countries with complete data, explains $39 \%$ of total variance, and achieves an F-value of 15.712 with an error probability of the entire equation of 0.000 . The insignificant constant has the value of -0.034. Women in government and worker remittances per GDP are the significant drivers of smart gender justice, while high military expenditures and the Muslim population share per total population are the major bottlenecks of smart gender justice.

Table 9

Drivers and Bottlenecks of Smart Gender Justice

\begin{tabular}{l|l|l|l}
\hline Independent Variable & B & Std error & Beta \\
\hline Constant & -0.034 & 0.213 & \\
\hline$\%$ women in government. all levels & $0.044 \mathrm{a}$ & 0.013 & 0.300 \\
\hline Military expenditures per GDP & $-0.087 \mathrm{~b}$ & 0.036 & -0.204 \\
\hline Worker remittance inflows as \% of GDP & $0.035 \mathrm{a}$ & 0.013 & 0.241 \\
\hline Muslim population share per total population & $-0.010 \mathrm{a}$ & 0.003 & -0.396 \\
\hline Statistical properties of the equation & adj R^2 & df & F \\
\hline Note: significant at <1\%(a), 1-5\%(b),6-10\%(c) & 39.000 & 92 & 15.712 \\
\hline
\end{tabular}


Table 10 looks at the drivers and bottlenecks of smart human development. On this scale the ten countries best combining the task of a maximum of human development with a minimum of ecological footprint per capita (see also Appendix Graph 2f) are Jamaica, the Philippines, Cuba, Sri Lanka, Costa Rica, Vietnam, the Dominican Republic, Indonesia, Colombia, and Moldova; while all the worst performers are located in the African continent: Botswana, Namibia, the Central African Republic, Burkina Faso, Niger, Sierra Leone, Zimbabwe, Mali, Angola, and Chad. Our equation explains $29.9 \%$ of the total variance of smart development and is based on the analysis of the 115 countries with complete data; the F-value is 13.183 and the error $\mathrm{p}$ of the entire equation is 0.000 . The constant, which is weakly significant, has a value of -1.657 . The drivers of smart human development are the share of a country's population in world population, indicating the relative size of a nation, the UNDP education index, measuring the levels of education in a given country, and worker remittance inflows as a percent of GDP. The bottleneck of smart human development is constituted by the crowding-out effect of public education expenditures on human development.

Table 10

Drivers and Bottlenecks of Smart Human Development

\begin{tabular}{l|l|l|l}
\hline Independent Variable & B & Std error & Beta \\
\hline Constant & $-1.657 \mathrm{a}$ & 0.348 & \\
\hline$\%$ world population & $0.055 \mathrm{c}$ & 0.029 & 0.152 \\
\hline Public education expenditure per GNP & $-0.097 \mathrm{~b}$ & 0.042 & -0.196 \\
\hline UNDP education index & $2.437 \mathrm{a}$ & 0.430 & 0.478 \\
\hline Worker remittance inflows as \% of GDP & $0.044 \mathrm{a}$ & 0.010 & 0.352 \\
\hline Statistical properties of the equation & adj R^2 & df & F \\
\hline Note: significant at $<1 \%(a), 1-5 \%(b), 6-10 \%(c)$ & 29.900 & 114 & 13.183 \\
\hline
\end{tabular}

Table 11 analyses the drivers and bottlenecks of smart R\&D performance. The equation is based on 93 countries with complete data; the $\mathrm{R}^{\wedge} 2$ is $33 \%$, the F-value is 10.058 , and the error probability of the entire equation is 0.000 . The constant, which is not significant, is 0.326 . The drivers of smart R\&D performance, combining the R\&D record with a minimum of ecological footprint (see also Appendix Graph 2g), are the dominant position of a country on the global markets, expressed in the indicator multinational corporation outward investments per GDP, the public education expenditure, and worker remittance inflows as a percentage of GDP. The significant bottlenecks against a smart R\&D performance are population pressure (the annual population growth rate) and world economic openness. According to our indicator, the best performing countries are the United States, Sweden, New Zealand, Finland, Israel, the United Kingdom, the Netherlands, Norway, Switzerland, and Kyrgyzstan. The worst performers are: the United Arab Emirates, Luxembourg, Kuwait, Namibia, Botswana, Cyprus, Bosnia and Herzegovina, Macedonia, Uruguay, and the Czech Republic. 
Table 11

Drivers and Bottlenecks of Smart R\&D

\begin{tabular}{l|l|l|l}
\hline Independent Variable & B & Std error & Beta \\
\hline Constant & 0.326 & 0.327 & \\
\hline Annual population growth rate. 1975-2005 (\%) & $-0.248 \mathrm{a}$ & 0.089 & -0.253 \\
\hline MNC outward investments (stock) per GDP & $0.043 \mathrm{a}$ & 0.009 & 0.479 \\
\hline $\begin{array}{l}\text { Openness-Index. 1990 (export-share + import-share per } \\
\text { GDP) }\end{array}$ & $-0.014 \mathrm{a}$ & 0.002 & -0.552 \\
\hline Public education expenditure per GNP & $0.136 \mathrm{a}$ & 0.051 & 0.235 \\
\hline Worker remittance inflows as \% of GDP & $0.050 \mathrm{~b}$ & 0.021 & 0.229 \\
\hline Statistical properties of the equation & adj R^2 & df & F \\
\hline Note: significant at <1\%(a), 1-5\%(b), 6-10\%(c) & 33.000 & 92 & 10.058 \\
\hline
\end{tabular}

Our last result is presented in Table 12. It features the preconditions of smart social cohesion, combining a relatively high social cohesion with a relatively low ecological footprint (see also Appendix Graph 2h). Our equation is based on an analysis of 120 countries with complete data, the adjusted $\mathrm{R}^{\wedge} 2$ is just $8.7 \%$; the F-value is 6.771 ; and the error probability of the entire equation is 0.002 . The constant is 0.824 and is significant. There are two significant bottlenecks and no positive drivers of smart social cohesion - annual population growth (population pressure) and the crowding-out effects of public education expenditures per GDP. The best results on our indicator are achieved by several less developed and/or (former) communist or left wing regime countries as well as nations with a known record of relatively egalitarian development policies (South Korea), with the entire group comprising Chad, Uzbekistan, Rwanda, Belarus, Laos, Cuba, Benin, Tajikistan, Korea (Republic of), and Thailand. The worst records of combing social cohesion with low ecological footprints were found in Djibouti, Namibia, Bosnia and Herzegovina, the Central African Republic, Sierra Leone, Botswana, Macedonia, Bolivia, South Africa, and Colombia.

Table 12

Drivers and Bottlenecks of Smart Social Cohesion

\begin{tabular}{l|l|l|l}
\hline Independent Variable & B & Std error & Beta \\
\hline Constant & $0.824 \mathrm{a}$ & 0.206 & \\
\hline Annual population growth rate. 1975-2005 (\%) & $-0.152 \mathrm{a}$ & 0.055 & -0.248 \\
\hline Public education expenditure per GNP & $-0.102 \mathrm{a}$ & 0.034 & -0.270 \\
\hline Statistical properties of the equation & adj R^2 & df & F \\
\hline Note: significant at $<1 \%(a), 1-5 \%(b), 6-10 \%(c)$ & 8.700 & 119 & 6.771 \\
\hline
\end{tabular}




\section{Discussion}

Our residuals-based reformulation of smart development realistically captures the tradeoff between the global ecological footprint per capita and development performance and offers us a better idea about smart development performance at different stages of socio-economic development. Our results show that traditional indicators of economic globalization and also inequality have little influence on smart development performance, but that hitherto neglected elements of dependency and world systems theory gain in importance. This is especially relevant for the socio-economic theory of Samir Amin, but it is also true of the contributions by feminism, peace research, and by other various approaches in the globalization critical tradition. Efficiency tends to increase and then to decrease with rising development levels. Big countries with large populations perform better on our scales, and military expenditures/personnel rates are a significant block against smart development performance. In a sense, our results also contradict the logic inherent in the 'beautiful', but unfortunately wrong 'small is beautiful' analysis proposed by Schumacher (1973a): It is not the small countries but rather the big countries that find it easier to have a satisfactory smart development performance in comparison to their ecological footprint. Our research also shows the beneficial effects of migration on the sending countries. Worker remittances have a significant positive effect on the HPI and a host of other smart development indicators. Migration sending countries, in accordance with Samir Amin's dependency theory, reap substantial benefits from receiving worker remittances, while other indicators of globalization hardly affect the smart development performance.

Only the following significant effects highlight the necessity to further develop the paradigm, as seen here in the negative, crowding out effects of public education expenditures per GDP on smart social cohesion and smart human development, and in the negative effects of worker remittance inflows as a percentage of GDP wield on smart economic growth. The impressive list of tests, speaking in favor of the globalization critical paradigm as presented in this work, would suggest further development of this research approach to questions of smart development.

First of all, the dependency and world systems paradigm laid out by Samir Amin comes to our mind. As correctly predicted by Samir Amin, the big countries with huge population resources today are favored in their smart economic growth, their Happy Life Years, and their smart human development. As correctly expected by Amin, peripheral rent seeking is a burden and its absence, measured by economic freedom, is an asset among the forces shaping international development today, especially for smart democracy and the overall smart development index. In addition, Amin correctly stresses the necessity for European integration, and the positive effects of years of EU membership on smart democracy confirm Euro-optimism. He correctly analyses the enormous transfer of resources from the center to the periphery, brought about by migration, with the huge statistical observed effects of received worker remittances on smart human development, Happy Life Years, smart gender justice, smart R\&D; both formulations of the smart development index justify his assumption. Amin's depen- 
dency theory correctly predicts the negative effects of world economic openness on smart development. The obvious huge statistical negative and uniform effects cannot be simply and easily rejected out of hand: smart R\&D and overall smart development are affected negatively by world economic openness. Among the major four founding figures of the world systems approach (Amin, Arrighi, Frank and Wallerstein, 1982), he is the only one to have come up, in addition, with a consistent and far-reaching critique of Islamism, confirmed by the negative trade-off between Muslim population share and smart gender empowerment.

But in some ways, Amin's paradigm has to be expanded and refined: Feminism is an important driver of smart gender justice, smart democracy, and the overall smart development index, based on 26 variables, weighted equally. Feminist approaches, in principle, would be well compatible with Amin's original approach. The Kalecki/Steindl paradigm also can be merged with Amin's theory, and it has three significant results in its favor - the positive determination of smart R\&D by public education expenditures, the positive effects of the UNDP education index on smart human development and also on overall smart development index, based on 26 variables, weighted equally. Several further strains of dependency/world systems research are confirmed in this essay: Bornschier's dependency theory and the importance it attaches to multinational corporation headquarter status, which is confirmed by the positive effect of this variable on smart R\&D; and the effect of population density, predicted in José Carlos Mariategui's dependency theory on the overall smart development index, based on 26 variables, weighted equally. Paul Israel Singer's approach to dependency and population dynamics is confirmed by the significant negative effects of annual population growth rates on smart $R \& D$ and smart social cohesion.

The following empirical results could be interpreted as expressions of Andre Gunder Frank's Re-Orient hypothesis (1999) concerning a fundamental shift in the global production dynamics away from the old centers and towards the countries of the Indian and Pacific Oceans. This relates to the significant positive effect of Muslim population share per total population on smart economic growth, and the significant negative effects of absolute latitude on smart economic growth, of immigration - share of population in 2005 on smart democracy (the biggest migration recipients are the countries of the global North), and worker remittance inflows as a percentage of GDP on smart economic growth.

For some other processes, Amin's empirical five monopolies of power include two elements of military might, the monopoly of technology, supported by military expenditures of the dominant nations, and the monopoly of the military means of mass destruction. However, the significant negative effects of military expenditures (on Happy Life Years, smart gender justice, the two formulations of the overall smart development index) or military personnel rates (smart democracy) on smart development support the arguments of quantitative peace research during the last decades with its warnings against high military spending rates (Auvinen and Nafziger, 1999; Heo, 1998; Mintz and Stevenson, 1995). 
As we stated, the real differences with the theories presented here are to be found in the negative effects of public education expenditures per GDP on smart social cohesion and smart human development. In this case, our response can only be to draw the attention of the global research community to the essays published by Blankenau and Simpson (2004) and Sylwester (2000), written from the perspective of established economic theory. Blankenau and Simpson (2004) investigate the public education expendituregrowth relationship in the context of an endogenous growth model in which private and public investment contribute to the discussion on human capital accumulation. They could show that the positive direct effect of public education spending on growth can be diminished or even negated when other determinants of growth are negatively affected by general equilibrium adjustments. Blankenau and Simpson showed that the response of growth to public education expenditures may be non-monotonic. The relationship depends on the level of government spending, the tax structure and the parameters of production technologies. Sylwester (2000), for his part, could demonstrate that although public education expenditures are positively associated with future economic growth, the contemporaneous effect upon growth is negative.

\section{Conclusions}

Since all existing major comparative empirical studies on drivers and bottlenecks of environmental quality only touched upon different dependent variables, and not on the smart development, this first international comparative study suggests cautiously that future research efforts in comparative environmental science would be well advised to take the major predictor variables of the present study into account as well as the environmental plateau curve (see also Weede and Kampf, 2002; de Haan, Lundstrom and Sturm, 2006; and Gwartney, Lawson and Holcombe, 1999).

It emerges that the absence of rent seeking, economic freedom and a free price mechanism, and worker remittances are the most important drivers of smart development. Most of the small is beautiful assumptions of Schumacherian economics by contrast do not stand the test of cross-national development accounting and are squarely contradicted by our empirical results; with population density and population size always being among the drivers, and not the bottlenecks of smart development.

As correctly predicted by Samir Amin, the big countries with huge population resources today are favored in their smart economic growth, their Happy Life Years, and their smart human development. As correctly expected by Amin, peripheral rent seeking is a burden and its absence, measured by economic freedom, is an asset among the forces shaping international development today, especially for smart democracy, and the overall smart development index. In addition, Amin correctly stressed the necessity for European integration, and the positive effects of years of EU membership on smart democracy confirm Euro-optimism. He correctly analyzed the enormous transfer of resources from the center to the periphery, brought about by migration, with the huge statistical observed effects of received worker remittances on smart human development, Happy Life Years, smart gender justice, smart R\&D, and both formulations of the smart 
development index. Amin's dependency theory correctly predicted the very negative effects of world economic openness on smart development. The huge statistical negative and very uniform effects, to be observed, cannot be simply and easily rejected out of hand: smart R\&D and overall smart development are affected negatively by world economic openness. Among the major four founding figures of the world systems approach (Amin, Arrighi, Frank and Wallerstein, 1982), he is the only one to have come up, in addition, with a consistent and far-reaching critique of Islamism, confirmed by the very negative trade-off between Muslim population share and smart gender empowerment.

We show in this article the importance of Feminism, the Kalecki/Steindl paradigm, the multinational corporation headquarter status, population density, population dynamics, Muslim population share per total population, absolute latitude, and migration on smart development. We also investigated the negative effects of public education expenditures per GDP on smart development.

We are aware that our answers to the questions in this article are incomplete. But we hope to have provided at least some preliminary guiding posts for further research on this important subject.

\section{Appendix}

Appendix Table 1a

\section{The Dependent Variables and Other Control Variables used in a Number of High-profile Studies in Economics.}

\begin{tabular}{l|l}
\hline 29 & Component UNDP-type index for overall democracy-performance \\
\hline 30 & Component UNDP-type index for overall economic growth-performance \\
\hline 31 & Component UNDP-type index for overall gender-performance \\
\hline 32 & Component UNDP-type index for overall human development-performance \\
\hline 34 & Component UNDP-type index for overall R\&D-performance \\
\hline 35 & component UNDP-type index for overall social cohesion-performance \\
\hline 36 & $\%$ world population \\
\hline 37 & 2000 Economic Freedom Score \\
\hline 38 & Absolute latitude \\
\hline 39 & Annual population growth rate, 1975-2005 (\%) \\
\hline 40 & Comparative price levels (US=1.00) \\
\hline 41 & Foreign savings rate \\
\hline 42 & FPZ (free production zones) employment as \% of total population \\
\hline 43 & Ln GDP per capita \\
\hline 44 & Ln GDP per capita ^2 \\
\hline 45 & Membership in the Islamic Conference (now: Cooperation) \\
\hline 46 & Military expenditures per GDP \\
\hline
\end{tabular}




\begin{tabular}{l|l}
\hline 47 & Military personnel rate ln (MPR+1) \\
\hline 48 & MNC outward investments (stock) per GDP \\
\hline 49 & MNC PEN - stock of Inward FDI per GDP \\
\hline 50 & MNC PEN: DYN MNC PEN 1995-2005 \\
\hline 52 & Openness-Index, 1990 (export-share per GDP + import-share per GDP) \\
\hline 53 & Public education expenditure per GNP \\
\hline 54 & UNDP education index \\
\hline 55 & Worker remittance inflows as \% of GDP \\
\hline 56 & Immigration - Share of population 2005 (\%) \\
\hline 57 & Muslim population share per total population \\
\hline 58 & Net international migration rate, 2005-2010 \\
\hline 59 & Years of membership in the EU, 2010 \\
\hline 60 & Years of membership in EMU, 2010 \\
\hline 61 & Social security expenditure per GDP average 1990s (ILO) \\
\hline 62 & Ecological footprint (g ha /cap) \\
\hline 63 & Ecological footprint (g ha /cap)^2 \\
\hline
\end{tabular}

\section{Appendix Table 1b \\ The Independent Variables of our Model and their Links to Earlier Empirical Studies}

\begin{tabular}{|c|c|}
\hline $\begin{array}{l}\text { Independent variables, } \\
\text { determinants of smart } \\
\text { development }\end{array}$ & Theories or earlier empirical studies, connected with these variables \\
\hline $\begin{array}{l}\% \text { women in government, all } \\
\text { levels }\end{array}$ & $\begin{array}{l}\text { Holmberg, Rothstein and Nasiritousi, 2009; Logo, 2008; Matt, 2010; } \\
\text { McDowell, 1992; Orloff, 1996; Rankin, 2002; Rothstein and Teorell; } \\
\text { UNDP, HDR, } 1995\end{array}$ \\
\hline$\%$ world population & $\begin{array}{l}\text { Acemoğlu and Dell, 2010; Acemoğlu and Robinson, 2000, 2001, 2006; } \\
\text { Acemoğlu, 2003, 2005, 2010a, 2010b; Acemoğlu, Johnson and Robinson, } \\
\text { 2001, 2002, 2005; Amin, 1997a, 1997b; Crenshaw and Robison, 2010; } \\
\text { Kohr, 1957, 1958, 1960, 1977, 1992; Ram, 1997; Schumacher, 1973a, } \\
\text { 1973b, 1976, 1977 }\end{array}$ \\
\hline $\begin{array}{l}2000 \text { Economic Freedom } \\
\text { Score }\end{array}$ & $\begin{array}{l}\text { Alesina and Perotti, 1994; Helliwell, 1994; La Porta, Lopez de Silanes, } \\
\text { Shleifer, 1999; York, Rosa and Dietz, } 2003\end{array}$ \\
\hline Absolute latitude & $\begin{array}{l}\text { Acemoğlu and Dell, 2010; Acemoğlu and Robinson, 2000, 2001, 2006; } \\
\text { Acemoğlu, 2003, 2005, 2010a, 2010b; Acemoğlu, Johnson and Robinson, } \\
\text { 2001, 2002, 2005; Easterly, 2000; Poe and Tate, 1994; Ram } 1997\end{array}$ \\
\hline $\begin{array}{l}\text { Annual population growth } \\
\text { rate, } 1975-2005(\%)\end{array}$ & $\begin{array}{l}\text { Acemoğlu and Dell, 2010; Acemoğlu and Robinson, 2000, 2001, 2006; } \\
\text { Acemoğlu, 2003, 2005, 2010a, 2010b; Acemoğlu, Johnson and Robinson, } \\
\text { 2001, 2002, 2005; Crenshaw and Robison, 2010; Ram, } 1997\end{array}$ \\
\hline $\begin{array}{l}\text { Comparative price levels } \\
(\mathrm{US}=1.00)\end{array}$ & $\begin{array}{l}\text { Egert, Drine and Lommatzsch, 2003; Faria and Leon-Ledesma, 2003; } \\
\text { Gould, 2002; Kohler and Tausch, 2003; Paya, Venetis and Peel, 2003; } \\
\text { Raffer, 1987; Tausch and Ghymers, 2006; Yotopoulos and Sawada, 2005; } \\
\text { Yotopoulos, } 1996\end{array}$ \\
\hline
\end{tabular}




\begin{tabular}{|c|c|}
\hline $\begin{array}{l}\text { Independent variables, } \\
\text { determinants of smart } \\
\text { development }\end{array}$ & Theories or earlier empirical studies, connected with these variables \\
\hline Foreign savings rate & $\begin{array}{l}\text { Bovenberg and van Ewijk, 1997; Cook, 1995; Doucouliagos and Paldam, } \\
\text { 2008; Easterly and Schmidthebbel, 1993; Feldstein, 1994; Gine and } \\
\text { Townsend, 2004; Singh, 1985; Tausch and Ghymers, 2006; Tausch and } \\
\text { Prager, 1993; Taylor, } 1992\end{array}$ \\
\hline $\begin{array}{l}\text { FPZ (free production zones) } \\
\text { employment as \% of total } \\
\text { population }\end{array}$ & $\begin{array}{l}\text { Chen, 1995; Rondinelli, 1987; Tausch and Ghymers, 2006; Tausch and } \\
\text { Prager, } 1993\end{array}$ \\
\hline $\begin{array}{l}\text { Immigration - Share of } \\
\text { population } 2005(\%)\end{array}$ & $\begin{array}{l}\text { Barro and Sala-i-Martin, 2003; Dixon and Moon, 1986, 1989; Dixon, } \\
\text { 1987; Durlauf } \text { et al., 2008; Fain, 1997; Fosu, 2009, 2010a, 2010b, 2010c; } \\
\text { Moon and Dixon, 1992; Shandra et al., 2009; Shandra, 2007a, 2007b; } \\
\text { Tausch and Prager, 1993 }\end{array}$ \\
\hline ln GDP per capita & $\begin{array}{l}\text { Afxentiou, 1990a, 1990b; Anand and Ravillion, 1993; Anson, 1988, 1991; } \\
\text { Barro, 2000; Cheng, 1989; Dixon and Moon, 1986, 1989; Dixon, 1987; } \\
\text { Fosu, 2009, 2010a, 2010b, 2010c; Kakwani, 1993, 1995; Khan, 1991; } \\
\text { King, 1998; Knight and Rosa, 2011; Mazumdar, 1996, 2000; Moon and } \\
\text { Dixon, 1992; Newman and Thomson, 1989; Rudra, 2009; Selden and } \\
\text { Song, 1994; Stern, 2004; Stern, Common and Barboer, 1996; Tausch and } \\
\text { Prager, 1993 }\end{array}$ \\
\hline $\ln$ GDP per capita ^2 & $\begin{array}{l}\text { Afxentiou, 1990a, 1990b; Anand and Ravillion, 1993; Anson, 1988, 1991; } \\
\text { Barro, 2000; Cheng, 1989; Dixon and Moon, 1986, 1989; Dixon, 1987; } \\
\text { Fosu, 2009, 2010a, 2010b, 2010c; Kakwani, 1993, 1995; Khan, 1991; } \\
\text { King, 1998; Knight and Rosa, 2011; Mazumdar, 1996, 2000; Moon and } \\
\text { Dixon, 1992; Newman and Thomson, 1989; Rudra, 2009; Selden and } \\
\text { Song, 1994; Stern, 2004; Stern, Common and Barboer, 1996; Tausch and } \\
\text { Prager, 1993 }\end{array}$ \\
\hline $\begin{array}{l}\text { Membership in the } \\
\text { Organization of Islamic } \\
\text { Cooperation (OIC) }\end{array}$ & de Soysa and Ragnhild, 2007; Haynes, 2001 \\
\hline $\begin{array}{l}\text { Military expenditures per } \\
\text { GDP }\end{array}$ & $\begin{array}{l}\text { Auvinen and Nafziger, 1999; Biswas and Ram, 1986; Brzoska and Lock, } \\
\text { 1992; Brzoska and Ohlson, 1986, 1987; Brzoska and Pearson, 1994; Heo, } \\
\text { 1998; Mintz and Stevenson, 1995 }\end{array}$ \\
\hline $\begin{array}{l}\text { Military personnel rate } \ln \\
(\text { MPR+1) }\end{array}$ & $\begin{array}{l}\text { Auvinen and Nafziger, 1999; Heo, 1998; Keller, Poutvaara, and Wagener, } \\
\text { 2010; Mintz and Stevenson, 1995; Weede and Jagodzinski, 1980; Weede } \\
\text { and Tiefenbach, 1980a, 1980b, 1981; Weede, 1980, 1981a, 1981b, 1983, } \\
\text { 1985, 1986, } 1993\end{array}$ \\
\hline $\begin{array}{l}\text { MNC outward investments } \\
\text { (stock) per GDP }\end{array}$ & $\begin{array}{l}\text { Beer, 1999; Bornschier, 1982, 2002; Dick and Jorgenson, 2010; Dutt, } \\
\text { 1997; Heshmati, 2006b; Jorgenson and Burns, 2007; Jorgenson, 2003, } \\
\text { 2004a, 2004b, 2005, 2006a, 2006b, 2007a, 2007b, 2008, 2009a, 2009b; } \\
\text { Jorgenson, and Burns, 2004; Jorgenson, Dick, and Mahutga, 2007; } \\
\text { Jorgenson, Kuykendall, and Kennon 2008; Kentor, 1998; Klitgaard and } \\
\text { Fedderke, 1995; Lawrence, 2009; Longo and York, 2008; Mostafa and } \\
\text { Nataraajan, 2009; Mostafa, 2010a, 2010b; Nugent, and Shandra, 2009; } \\
\text { Shandra, 2007a, 2007b; Shandra, and London, 2008; Shandra, Leckband, } \\
\text { and London, 2009; Shandra, Leckband, McKinney, and London 2009; } \\
\text { Shandra, London, Whooley, and Williamson, 2004; Shandra, Shor, and } \\
\text { London, 2008, 2009; Tausch and Prager, 1993; Tausch, 2003; Tsai } 1995\end{array}$ \\
\hline
\end{tabular}




\section{Independent variables, determinants of smart development} FDI per GDP

MNC PEN - stock of Inward

MNC PEN: DYN MNC PEN
1995-2005

1995-2005

\section{Theories or earlier empirical studies, connected with these variables}

Beer, 1999; Bornschier, 1982, 2002; Dick and Jorgenson, 2010; Dutt, 1997; Heshmati, 2006b; Jorgenson and Burns, 2007; Jorgenson, 2003, 2004a, 2004b, 2005, 2006a, 2006b, 2007a, 2007b, 2008, 2009a, 2009b; Jorgenson, and Burns, 2004; Jorgenson, Dick, and Mahutga, 2007; Jorgenson, Kuykendall, and Kennon 2008; Kentor, 1998; Klitgaard and Fedderke, 1995; Lawrence, 2009; Longo and York, 2008; Mostafa and Nataraajan, 2009; Mostafa, 2010a, 2010b; Nugent, and Shandra, 2009; Shandra, 2007a, 2007b; Shandra, and London, 2008; Shandra, Leckband, and London, 2009; Shandra, Leckband, McKinney, and London 2009; Shandra, London, Whooley, and Williamson, 2004; Shandra, Shor, and London, 2008, 2009; Tausch and Prager, 1993; Tausch, 2003; Tsai 1995

Beer, 1999; Bornschier, 1982, 2002; Dick and Jorgenson, 2010; Dutt, 1997; Heshmati, 2006b; Jorgenson and Burns, 2007; Jorgenson, 2003, 2004a, 2004b, 2005, 2006a, 2006b, 2007a, 2007b, 2008, 2009a, 2009b; Jorgenson, and Burns, 2004; Jorgenson, Dick, and Mahutga, 2007; Jorgenson, Kuykendall, and Kennon 2008; Kentor, 1998; Klitgaard and Fedderke, 1995; Lawrence, 2009; Longo and York, 2008; Mostafa and Nataraajan, 2009; Mostafa, 2010a, 2010b; Nugent, and Shandra, 2009; Shandra, 2007a, 2007b; Shandra, and London, 2008; Shandra, Leckband, and London, 2009; Shandra, Leckband, McKinney, and London 2009; Shandra, London, Whooley, and Williamson, 2004; Shandra, Shor, and London, 2008, 2009; Tausch and Prager, 1993; Tausch, 2003; Tsai 1995

Acemoğlu and Dell, 2010; Acemoğlu and Robinson, 2000, 2001, 2006; Acemoğlu, 2003, 2005, 2010a, 2010b; Acemoğlu, Johnson and Robinson, 2001, 2002, 2005; Ram, 1997

Muslim population share per total population

Ehrhardt-Martinez, Crenshaw and Jenkins, 2002

Net international migration rate, 2005-2010

Openness-Index, 1990 (export-share per GDP + import-share per GDP)

Alesina, Spolaore and Wacziarg, 2000; Dollar, 1992a, 1992b; Edwards, 1993; Frankel and Romer, 1999; Rodrik, 2006; Rodrik, Subramanian, and Trebbi, 2004; World Bank, 2005

Acemoğlu and Dell, 2010; Acemğglu and Robinson, 2000, 2001, 2006;

Population density Acemoğlu, 2003, 2005, 2010a, 2010b; Acemoğlu, Johnson and Robinson, 2001, 2002, 2005; Ram, 1997

Public education expenditure
per GNP
Blankenau and Simpson, 2004; Glomm and Ravikumar, 1997; Ram, 1986; Scanlan, 2004; Sylwester, 2000; Weede and Kampf, 2002

UNDP education index Blankenau and Simpson, 2004; Glomm and Ravikumar, 1997; Sylwester, 2000; Weede and Kampf, 2002

Worker remittance inflows as $\%$ of GDP Acosta, Calderon, Fajnzylber, et al., 2008; Amuedo-Dorantes and Pozo, 2004; Martin and Straubhaar, 2002

Years of membership in EMU, 2010 Allsopp and Artis, 2003; Buti, Franco and Ongena, 1998; de la Porte, Pochet and Room, 2001; Egert, Drine and Lommatzsch, 2003; Molle and Boeckhout, 1995

Allsopp and Artis, 2003; Buti, Franco and Ongena, 1998; de la Porte, Pochet and Room, 2001; Egert, Drine and Lommatzsch, 2003; Molle and Boeckhout, 1995 
Appendix Graph 2

Ecological footprint and general development performance - the non-linear tradeoffs

Graph $2 \mathrm{a}$

Ecological Footprint and the General Development Performance Index, Based on an Equal Weighting of its 26 Components

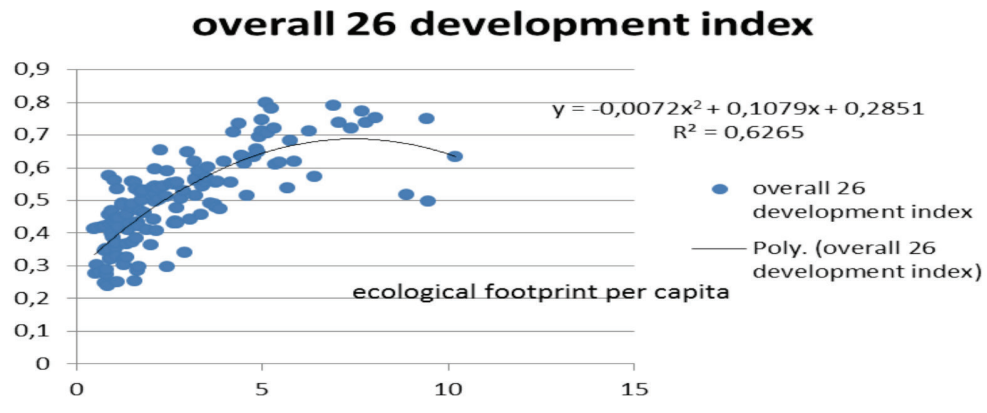

Graph 2b

Ecological Footprint and the General Development Performance Index, based on an Equal Weighting of the Six Dimensions, Underlying the 26 Components

\section{overall 26 development index, based on 6 dimensions}

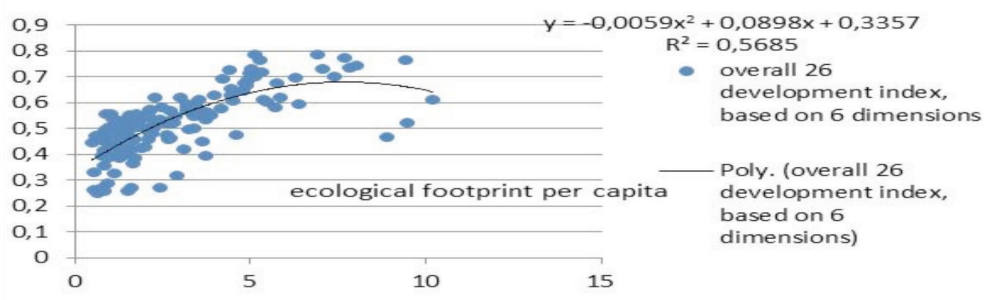

Graph 2c

Ecological Footprint and Democratic Performance (6 components combined)

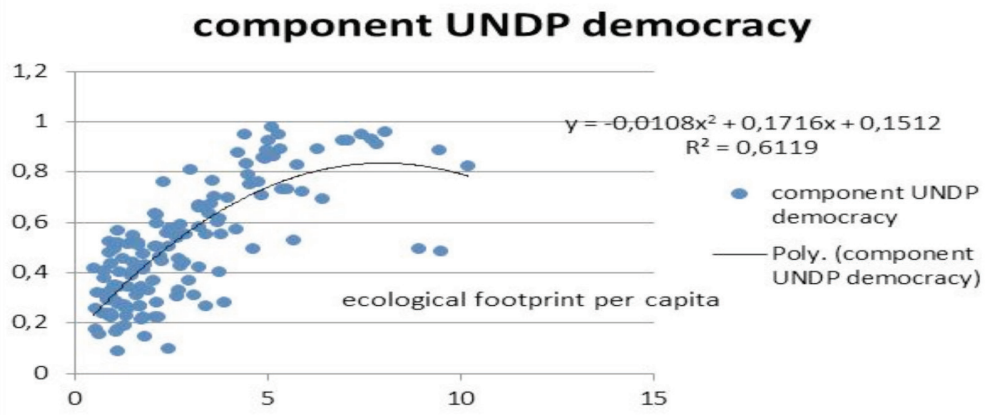


Graph 2d

Ecological Footprint and Economic Growth Performance (4 components combined)

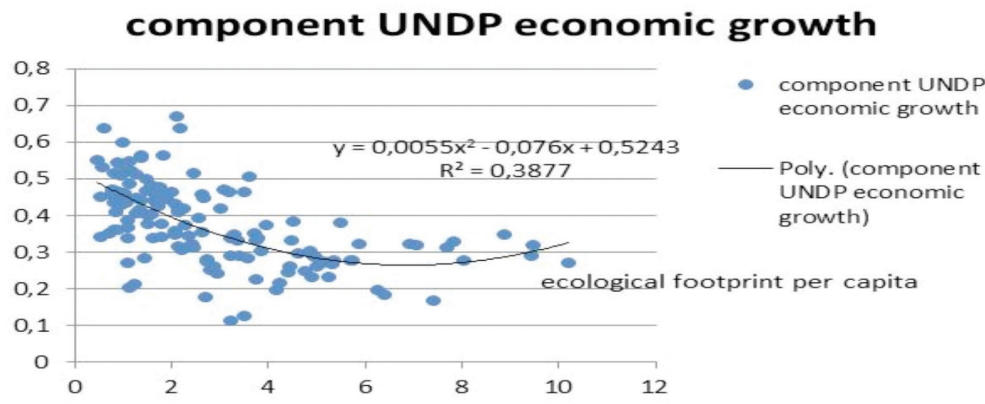

Graph 2e

Ecological Footprint and Gender Equality Performance (6 components combined)

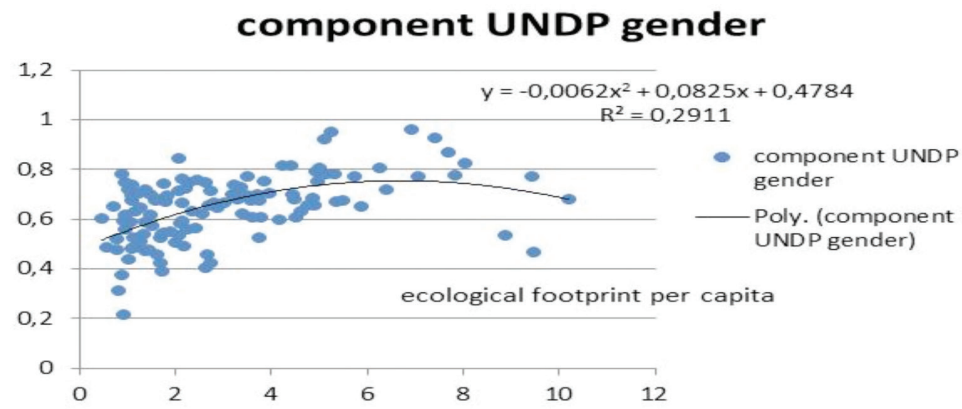

Graph $2 \mathrm{f}$

Ecological Footprint and Human Development Performance (5 components combined)

component UNDP human development

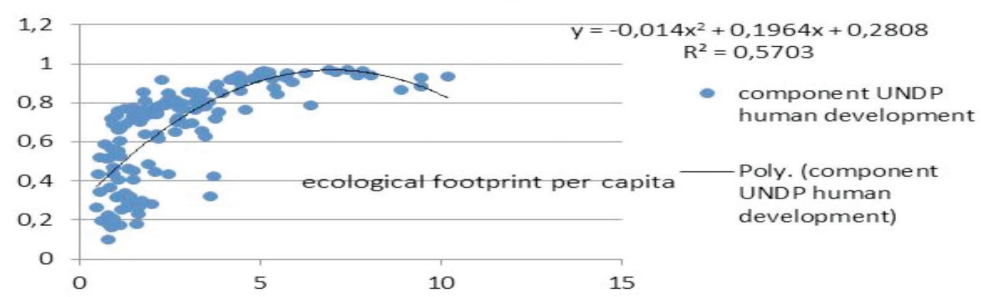


Graph $2 \mathrm{~g}$

Ecological Footprint and Research and Development Performance (3 components combined)

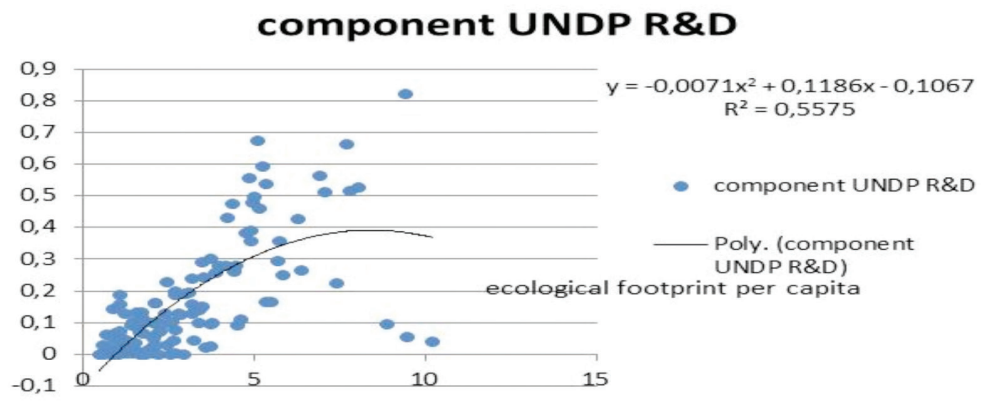

Graph $2 \mathrm{~h}$

Ecological Footprint and Docial Cohesion Performance (2 components combined)

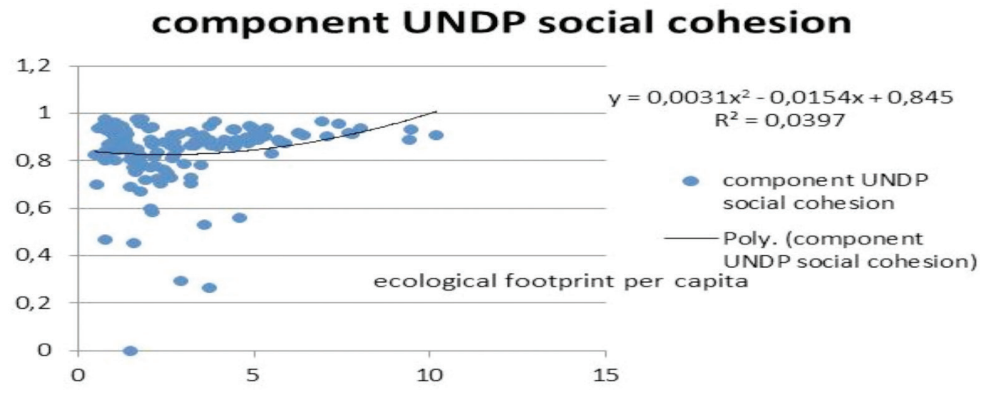

Appendix Table 2

Global Smart Development, Residual Component, Sorted by Overall Development Index Based on Six Dimensions

\begin{tabular}{|c|c|c|c|c|c|c|c|c|}
\hline Country & $\begin{array}{l}\text { Overall } \\
26 \text { devel- } \\
\text { opment } \\
\text { index }\end{array}$ & $\begin{array}{l}\text { Overall } \\
26 \text { devel- } \\
\text { opment } \\
\text { index, } \\
\text { based } \\
\text { on six } \\
\text { dimen- } \\
\text { sions }\end{array}$ & $\begin{array}{l}\text { UNDP } \\
\text { democ- } \\
\text { racy }\end{array}$ & $\begin{array}{l}\text { UNDP } \\
\text { eco- } \\
\text { nomic } \\
\text { growth }\end{array}$ & $\begin{array}{l}\text { UNDP } \\
\text { gender }\end{array}$ & $\begin{array}{l}\text { UNDP } \\
\text { human } \\
\text { develop- } \\
\text { ment }\end{array}$ & $\begin{array}{l}\text { UNDP } \\
\text { R\&D }\end{array}$ & $\begin{array}{l}\text { UNDP } \\
\text { social } \\
\text { cohesion }\end{array}$ \\
\hline Sudan & -2.512 & -3.117 & -2.788 & 1.650 & & -1.516 & -0.941 & \\
\hline $\begin{array}{l}\text { Bosnia and } \\
\text { Herzegovina }\end{array}$ & -2.381 & -2.858 & -1.304 & -1.251 & & -0.270 & -1.536 & -3.805 \\
\hline Kuwait & -1.887 & -2.552 & -2.290 & 0.693 & -1.717 & -0.328 & -2.514 & \\
\hline Djibouti & -0.705 & -2.500 & 0.185 & 0.478 & & -0.853 & -0.437 & -5.940 \\
\hline
\end{tabular}




\begin{tabular}{|c|c|c|c|c|c|c|c|c|}
\hline Country & $\begin{array}{l}\text { Overall } \\
26 \text { devel- } \\
\text { opment } \\
\text { index }\end{array}$ & $\begin{array}{l}\text { Overall } \\
26 \text { devel- } \\
\text { opment } \\
\text { index, } \\
\text { based } \\
\text { on six } \\
\text { dimen- } \\
\text { sions }\end{array}$ & $\begin{array}{l}\text { UNDP } \\
\text { democ- } \\
\text { racy }\end{array}$ & $\begin{array}{l}\text { UNDP } \\
\text { eco- } \\
\text { nomic } \\
\text { growth }\end{array}$ & $\begin{array}{l}\text { UNDP } \\
\text { gender }\end{array}$ & $\begin{array}{l}\text { UNDP } \\
\text { human } \\
\text { develop- } \\
\text { ment }\end{array}$ & $\begin{array}{l}\text { UNDP } \\
\text { R\&D }\end{array}$ & $\begin{array}{l}\text { UNDP } \\
\text { social } \\
\text { cohesion }\end{array}$ \\
\hline Namibia & -1.185 & -2.428 & -0.260 & 0.362 & -0.013 & -2.457 & -1.797 & -4.061 \\
\hline $\begin{array}{l}\text { Central African } \\
\text { Republic }\end{array}$ & -2.214 & -2.410 & -0.565 & -0.190 & & -2.382 & -0.480 & -2.692 \\
\hline Macedonia & -1.396 & -1.853 & -1.499 & 0.047 & -0.839 & -0.760 & -1.529 & -2.020 \\
\hline Togo & -0.979 & -1.830 & 0.075 & -1.201 & & -0.423 & 0.255 & \\
\hline $\begin{array}{l}\text { Congo } \\
\text { (Democratic } \\
\text { Republic of the) }\end{array}$ & -0.850 & -1.756 & -0.657 & 1.822 & & -1.249 & 0.315 & \\
\hline Lebanon & -1.299 & -1.731 & -1.842 & 1.470 & & -0.339 & 0.015 & \\
\hline $\begin{array}{l}\text { United Arab } \\
\text { Emirates }\end{array}$ & -1.970 & -1.725 & -2.260 & 0.211 & -2.158 & -0.003 & -2.816 & -0.310 \\
\hline Botswana & -1.075 & -1.684 & 0.524 & 2.091 & -0.787 & -3.052 & -1.789 & -2.127 \\
\hline Sierra Leone & -1.400 & -1.617 & 0.271 & 0.007 & & -2.032 & 0.241 & -2.645 \\
\hline Angola & -0.669 & -1.543 & -0.511 & 0.053 & 0.423 & -1.811 & 0.057 & \\
\hline Congo & -0.481 & -1.488 & 0.125 & -0.376 & & -0.242 & 0.380 & \\
\hline Zimbabwe & -1.750 & -1.264 & -1.035 & -2.819 & -0.314 & -1.956 & -0.004 & 0.268 \\
\hline Niger & -1.888 & -1.257 & -0.500 & 0.306 & & -2.104 & -0.537 & -0.029 \\
\hline Chad & -1.827 & -1.084 & -1.350 & 0.144 & -1.876 & -1.749 & -0.614 & 1.071 \\
\hline Estonia & -1.303 & -0.972 & -0.788 & -0.956 & -0.319 & -1.091 & -0.850 & 0.258 \\
\hline Turkey & -1.134 & -0.946 & -0.744 & -0.902 & -2.091 & 0.100 & -0.729 & -0.004 \\
\hline Iran & -1.021 & -0.934 & -1.376 & 1.002 & -1.785 & -0.012 & -1.341 & -0.111 \\
\hline $\begin{array}{l}\text { Hong Kong, } \\
\text { China (SAR) }\end{array}$ & -1.528 & -0.921 & -1.728 & 0.077 & & -0.106 & -0.400 & 0.236 \\
\hline Kazakhstan & -1.327 & -0.882 & -2.334 & 0.008 & 0.365 & -0.797 & -0.614 & 0.384 \\
\hline Paraguay & -0.519 & -0.849 & -1.164 & 0.016 & 0.195 & -0.014 & -1.339 & -0.894 \\
\hline Burkina Faso & -1.312 & -0.817 & -0.556 & 0.784 & -1.033 & -2.120 & -0.850 & 0.800 \\
\hline Mauritania & -0.643 & -0.758 & -0.737 & 0.513 & -0.557 & -0.733 & -0.663 & -0.782 \\
\hline Saudi Arabia & -1.064 & -0.701 & -1.522 & -0.096 & -2.211 & 0.718 & -0.443 & 0.271 \\
\hline Cameroon & -1.097 & -0.699 & -1.098 & -0.343 & -0.571 & -1.220 & -0.095 & 0.221 \\
\hline Russia & -1.324 & -0.681 & -1.631 & -1.070 & -0.230 & -0.645 & 0.546 & 0.399 \\
\hline Haiti & -0.765 & -0.632 & -0.423 & -1.672 & & 0.349 & 0.388 & -0.970 \\
\hline Burundi & -1.598 & -0.624 & -0.360 & -0.660 & & -1.480 & 0.142 & 0.738 \\
\hline Nigeria & -1.092 & -0.610 & -0.907 & -0.198 & -0.341 & -1.463 & -0.181 & 0.430 \\
\hline Uruguay & -0.508 & -0.591 & -0.227 & 1.197 & -0.628 & -0.574 & -1.420 & -0.176 \\
\hline Mali & -0.687 & -0.559 & 0.751 & 0.724 & -1.239 & -1.889 & -0.508 & -0.127 \\
\hline
\end{tabular}




\begin{tabular}{|c|c|c|c|c|c|c|c|c|}
\hline Country & 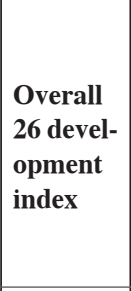 & \begin{tabular}{|l|} 
Overall \\
26 devel- \\
opment \\
index, \\
based \\
on six \\
dimen- \\
sions \\
\end{tabular} & $\begin{array}{l}\text { UNDP } \\
\text { democ- } \\
\text { racy }\end{array}$ & $\begin{array}{l}\text { UNDP } \\
\text { eco- } \\
\text { nomic } \\
\text { growth }\end{array}$ & $\begin{array}{l}\text { UNDP } \\
\text { gender }\end{array}$ & $\begin{array}{l}\text { UNDP } \\
\text { human } \\
\text { develop- } \\
\text { ment }\end{array}$ & $\begin{array}{l}\text { UNDP } \\
\text { R\&D }\end{array}$ & $\begin{array}{l}\text { UNDP } \\
\text { social } \\
\text { cohesion }\end{array}$ \\
\hline Guinea & -1.292 & -0.557 & -0.553 & 0.120 & & -1.047 & -0.243 & 0.603 \\
\hline Belarus & -1.445 & -0.537 & -2.546 & -0.141 & 0.419 & -0.489 & 0.097 & 0.960 \\
\hline Greece & -0.612 & -0.494 & -0.430 & 0.604 & -0.904 & -0.273 & -0.834 & 0.113 \\
\hline Syria & -0.427 & -0.494 & -1.629 & 0.454 & -0.790 & 0.798 & -0.705 & -0.384 \\
\hline Czech Republic & -0.564 & -0.485 & -0.195 & 0.019 & -0.643 & -0.337 & -1.381 & 0.602 \\
\hline Malta & -0.404 & -0.401 & -0.643 & 0.267 & -0.868 & 0.470 & -1.227 & 0.234 \\
\hline Singapore & -0.643 & -0.401 & -0.722 & -1.257 & -1.033 & 0.386 & 0.131 & 0.399 \\
\hline Luxembourg & -0.010 & -0.394 & 0.308 & -0.634 & 0.016 & 0.713 & -2.801 & -0.709 \\
\hline Yemen & -0.705 & -0.356 & -0.401 & 0.943 & -2.996 & 0.145 & 0.038 & 0.020 \\
\hline Mexico & -0.288 & -0.297 & -0.358 & -0.468 & -0.564 & 0.407 & -0.983 & 0.322 \\
\hline $\begin{array}{l}\text { Korea (Republic } \\
\text { of) }\end{array}$ & -0.390 & -0.293 & -0.157 & 0.164 & -1.589 & 0.376 & -1.217 & 0.833 \\
\hline Azerbaijan & -0.923 & -0.260 & -1.699 & 2.893 & -1.237 & -0.152 & -0.129 & -0.057 \\
\hline Venezuela & -0.302 & -0.240 & -0.720 & -1.194 & 0.023 & 0.484 & -0.349 & 0.155 \\
\hline Ukraine & -0.571 & -0.213 & -0.542 & -2.114 & -0.004 & 0.043 & 0.314 & 0.579 \\
\hline Bolivia & 0.200 & -0.201 & 0.273 & 0.332 & -0.293 & 0.037 & 0.431 & -1.748 \\
\hline Ethiopia & -0.626 & -0.198 & -0.120 & 1.498 & -0.950 & -1.593 & -0.297 & 0.701 \\
\hline Cyprus & -0.122 & -0.191 & 0.314 & 1.022 & -1.037 & 0.214 & -1.654 & 0.345 \\
\hline Egypt & -0.294 & -0.158 & -0.946 & 0.463 & -1.556 & 1.053 & -0.609 & 0.174 \\
\hline Mongolia & -0.051 & -0.150 & 0.373 & 1.579 & 0.022 & -1.043 & -0.594 & -0.337 \\
\hline Myanmar & -0.799 & -0.150 & -1.636 & 1.165 & & 0.274 & 0.305 & 0.228 \\
\hline Rwanda & -1.105 & -0.129 & -0.270 & 0.548 & & -1.277 & 0.202 & 1.012 \\
\hline Zambia & -0.226 & -0.110 & 0.731 & -0.100 & -0.162 & -1.545 & 0.254 & -0.228 \\
\hline Algeria & -0.151 & -0.098 & -0.941 & 0.245 & -0.643 & 0.840 & -0.028 & -0.461 \\
\hline Albania & 0.172 & -0.074 & -0.216 & 0.404 & -0.661 & 0.870 & -0.465 & -0.724 \\
\hline Belize & 0.466 & -0.052 & 0.301 & 0.296 & -0.222 & 0.732 & -1.286 & -0.543 \\
\hline Guyana & 0.372 & -0.033 & 0.100 & 1.092 & 0.854 & -0.297 & -0.967 & -0.707 \\
\hline South Africa & 0.682 & -0.013 & 1.216 & -0.472 & 2.001 & -1.156 & -0.086 & -1.625 \\
\hline Kenya & -0.287 & -0.009 & -0.220 & -0.158 & 0.245 & -0.966 & 0.006 & 0.473 \\
\hline Romania & -0.091 & 0.009 & 0.012 & -1.035 & -0.143 & 0.274 & -0.436 & 0.607 \\
\hline Croatia & 0.105 & 0.050 & -0.057 & -0.553 & 0.128 & 0.480 & -0.614 & 0.279 \\
\hline Ecuador & 0.597 & 0.055 & -0.065 & -0.886 & 0.833 & 0.874 & -1.027 & -0.363 \\
\hline Latvia & -0.218 & 0.069 & 0.132 & -2.330 & 0.740 & -0.094 & 0.585 & 0.464 \\
\hline
\end{tabular}




\begin{tabular}{|c|c|c|c|c|c|c|c|c|}
\hline Country & $\begin{array}{l}\text { Overall } \\
26 \text { devel- } \\
\text { opment } \\
\text { index }\end{array}$ & \begin{tabular}{|l|} 
Overall \\
26 devel- \\
opment \\
index, \\
based \\
on six \\
dimen- \\
sions \\
\end{tabular} & $\begin{array}{l}\text { UNDP } \\
\text { democ- } \\
\text { racy }\end{array}$ & $\begin{array}{l}\text { UNDP } \\
\text { eco- } \\
\text { nomic } \\
\text { growth }\end{array}$ & $\begin{array}{l}\text { UNDP } \\
\text { gender }\end{array}$ & $\begin{array}{l}\text { UNDP } \\
\text { human } \\
\text { develop- } \\
\text { ment }\end{array}$ & $\begin{array}{l}\text { UNDP } \\
\text { R\&D }\end{array}$ & $\begin{array}{l}\text { UNDP } \\
\text { social } \\
\text { cohesion }\end{array}$ \\
\hline Brazil & 0.547 & 0.076 & 0.432 & -0.351 & -0.061 & 0.783 & -0.342 & -0.860 \\
\hline Portugal & 0.183 & 0.135 & 0.926 & -0.428 & -0.197 & -0.088 & -0.175 & 0.162 \\
\hline Pakistan & -0.224 & 0.146 & 0.154 & -0.359 & -2.079 & 0.567 & 0.118 & 0.669 \\
\hline Italy & -0.010 & 0.183 & 0.262 & -0.481 & -0.658 & 0.173 & 0.714 & 0.392 \\
\hline Uganda & -0.127 & 0.204 & -0.740 & 1.444 & 1.261 & -1.262 & -0.261 & 0.598 \\
\hline Malaysia & 0.099 & 0.205 & 0.031 & -0.596 & -0.679 & 0.853 & -0.088 & 0.365 \\
\hline Laos & -0.435 & 0.209 & -1.066 & 0.788 & & 0.519 & -0.091 & 0.939 \\
\hline Armenia & 0.034 & 0.216 & 0.095 & -1.643 & -0.964 & 1.129 & 0.362 & 0.253 \\
\hline Lithuania & 0.059 & 0.224 & 0.564 & -2.577 & 0.517 & 0.229 & 0.343 & 0.670 \\
\hline Slovakia & 0.332 & 0.226 & 0.432 & 0.161 & -0.037 & 0.312 & -0.587 & 0.247 \\
\hline Spain & 0.204 & 0.240 & 0.323 & 0.058 & 0.226 & 0.029 & 0.130 & 0.143 \\
\hline Iceland & 0.389 & 0.248 & 0.837 & -1.138 & 1.598 & 0.024 & -1.379 & 0.392 \\
\hline Uzbekistan & 0.046 & 0.310 & -1.931 & 1.830 & 0.796 & 0.315 & -0.727 & 1.055 \\
\hline Tanzania & 0.222 & 0.311 & 0.508 & 0.890 & 0.606 & -1.455 & -0.153 & 0.592 \\
\hline Colombia & 0.880 & 0.347 & 0.058 & -0.755 & 0.612 & 1.404 & 0.198 & -1.137 \\
\hline Poland & 0.233 & 0.349 & 0.255 & 0.733 & -0.040 & 0.058 & 0.236 & 0.191 \\
\hline Benin & 0.010 & 0.351 & 1.383 & -0.079 & -1.054 & -0.921 & 0.081 & 0.896 \\
\hline Ireland & 0.417 & 0.381 & 0.618 & -0.794 & 0.489 & -0.044 & 0.564 & 0.333 \\
\hline Japan & 0.104 & 0.384 & 0.889 & -0.609 & -0.705 & 0.193 & 0.462 & 0.744 \\
\hline Panama & 0.765 & 0.396 & 0.492 & 1.456 & 0.194 & 0.555 & -0.346 & -0.720 \\
\hline Cambodia & 0.228 & 0.398 & 0.045 & -0.337 & 0.067 & -0.117 & 0.109 & 0.752 \\
\hline Slovenia & 0.174 & 0.410 & 0.606 & 0.430 & -0.392 & 0.138 & -0.018 & 0.671 \\
\hline Hungary & 0.280 & 0.410 & 0.986 & -0.467 & -0.172 & 0.015 & 0.137 & 0.575 \\
\hline Bulgaria & 0.375 & 0.422 & 0.376 & -0.981 & 0.498 & 0.398 & 0.201 & 0.397 \\
\hline Jordan & 0.232 & 0.425 & -0.467 & 0.519 & -0.558 & 1.033 & 0.474 & -0.023 \\
\hline Ghana & 0.559 & 0.437 & 1.006 & 0.865 & 0.285 & -0.560 & -0.342 & 0.033 \\
\hline Guatemala & 0.694 & 0.471 & 0.392 & -0.538 & -0.123 & 1.204 & -0.154 & -0.171 \\
\hline Tunisia & 0.584 & 0.497 & -0.027 & 0.798 & -0.555 & 1.143 & 0.156 & -0.249 \\
\hline Israel & 0.218 & 0.528 & -0.155 & 0.204 & -0.416 & 0.135 & 2.179 & 0.211 \\
\hline Senegal & 0.476 & 0.537 & 1.064 & 0.113 & 0.099 & -0.378 & -0.219 & 0.581 \\
\hline Honduras & 0.847 & 0.577 & 0.376 & -0.359 & 0.604 & 0.866 & -0.128 & -0.040 \\
\hline Madagascar & 0.638 & 0.595 & 1.378 & -1.269 & 1.024 & -0.445 & -0.038 & 0.412 \\
\hline Georgia & 0.433 & 0.602 & 0.207 & -0.708 & -0.702 & 1.162 & 1.240 & -0.226 \\
\hline
\end{tabular}




\begin{tabular}{|c|c|c|c|c|c|c|c|c|}
\hline Country & $\begin{array}{l}\text { Overall } \\
26 \text { devel- } \\
\text { opment } \\
\text { index }\end{array}$ & \begin{tabular}{|l|} 
Overall \\
26 devel- \\
opment \\
index, \\
based \\
on six \\
dimen- \\
sions \\
\end{tabular} & $\begin{array}{l}\text { UNDP } \\
\text { democ- } \\
\text { racy }\end{array}$ & $\begin{array}{l}\text { UNDP } \\
\text { eco- } \\
\text { nomic } \\
\text { growth }\end{array}$ & $\begin{array}{l}\text { UNDP } \\
\text { gender }\end{array}$ & $\begin{array}{l}\text { UNDP } \\
\text { human } \\
\text { develop- } \\
\text { ment }\end{array}$ & $\begin{array}{l}\text { UNDP } \\
\text { R\&D }\end{array}$ & $\begin{array}{l}\text { UNDP } \\
\text { social } \\
\text { cohesion }\end{array}$ \\
\hline Nicaragua & 0.728 & 0.611 & 0.338 & -0.396 & 0.850 & 0.756 & -0.471 & 0.433 \\
\hline China & 0.438 & 0.626 & -1.255 & 3.239 & -0.380 & 0.893 & -0.093 & 0.391 \\
\hline Morocco & 0.581 & 0.632 & 0.119 & 0.450 & -0.688 & 1.164 & 0.238 & 0.093 \\
\hline Nepal & 0.689 & 0.649 & 0.922 & -0.174 & -0.539 & 0.583 & 0.344 & 0.026 \\
\hline France & 0.650 & 0.662 & 0.812 & 0.060 & 0.492 & 0.132 & 0.711 & 0.271 \\
\hline El Salvador & 1.137 & 0.681 & 0.834 & -0.908 & 0.751 & 1.180 & 0.108 & -0.531 \\
\hline Canada & 0.610 & 0.682 & 0.682 & 0.632 & 0.179 & -0.066 & 1.140 & 0.109 \\
\hline Australia & 0.598 & 0.698 & 0.542 & 0.689 & 0.276 & 0.025 & 1.080 & 0.013 \\
\hline Belgium & 0.692 & 0.730 & 0.793 & -0.063 & 0.369 & 0.119 & 1.217 & 0.293 \\
\hline Mozambique & 0.591 & 0.737 & 0.934 & 0.580 & 1.791 & -1.545 & 0.032 & 0.732 \\
\hline Argentina & 0.998 & 0.764 & 0.509 & -0.684 & 1.020 & 1.084 & 0.743 & -0.462 \\
\hline Denmark & 0.792 & 0.821 & 0.865 & 0.059 & 0.736 & -0.085 & 1.162 & 0.135 \\
\hline Malawi & 0.932 & 0.848 & 1.309 & 0.696 & 0.773 & -0.646 & 0.448 & -0.080 \\
\hline Chile & 1.240 & 0.866 & 1.678 & 0.826 & -0.038 & 0.697 & 0.062 & -0.295 \\
\hline Bhutan & 0.608 & 0.879 & 0.295 & 1.677 & & 0.619 & -0.037 & 0.710 \\
\hline Thailand & 0.732 & 0.879 & 0.894 & -0.825 & 0.348 & 0.670 & 0.406 & 0.831 \\
\hline United Kingdom & 0.777 & 0.881 & 0.918 & -0.120 & 0.361 & -0.017 & 1.832 & 0.364 \\
\hline $\begin{array}{l}\text { Trinidad and } \\
\text { Tobago }\end{array}$ & 1.385 & 0.943 & 1.122 & 0.241 & 1.232 & 0.750 & -0.729 & 0.304 \\
\hline Austria & 0.835 & 0.982 & 1.041 & 0.053 & 0.151 & 0.242 & 1.441 & 0.669 \\
\hline Tajikistan & 0.749 & 0.988 & -0.185 & -1.399 & 1.076 & 1.110 & 0.769 & 0.839 \\
\hline Cuba & 0.940 & 0.990 & -1.333 & 0.374 & 1.230 & 1.707 & 0.256 & 0.910 \\
\hline Germany & 1.164 & 1.009 & 1.357 & -0.981 & 0.883 & 0.385 & 1.387 & 0.338 \\
\hline $\begin{array}{l}\text { Dominican } \\
\text { Republic }\end{array}$ & 1.560 & 1.014 & 1.149 & -0.228 & 1.015 & 1.488 & 0.429 & -1.009 \\
\hline Moldova & 1.020 & 1.030 & 0.781 & -2.607 & 1.223 & 1.211 & 0.843 & 0.630 \\
\hline Kyrgyzstan & 0.639 & 1.058 & -0.330 & -0.930 & 1.586 & 0.789 & 1.482 & 0.436 \\
\hline Bangladesh & 0.867 & 1.076 & 0.518 & 0.562 & -0.344 & 0.846 & 0.598 & 0.711 \\
\hline India & 0.976 & 1.082 & 1.581 & 0.962 & -1.535 & 0.754 & 0.501 & 0.635 \\
\hline Indonesia & 1.047 & 1.102 & 0.183 & -0.154 & 0.594 & 1.480 & 0.569 & 0.293 \\
\hline Peru & 1.426 & 1.135 & 0.885 & 0.713 & 0.756 & 1.105 & 0.595 & -0.383 \\
\hline Vietnam & 0.931 & 1.137 & -0.595 & 0.853 & 0.678 & 1.650 & 0.100 & 0.830 \\
\hline Switzerland & 1.236 & 1.156 & 1.309 & -0.241 & 0.636 & 0.288 & 1.606 & 0.595 \\
\hline New Zealand & 1.037 & 1.158 & 0.681 & 0.509 & 1.070 & -0.114 & 2.343 & 0.052 \\
\hline
\end{tabular}




\begin{tabular}{l|l|l|l|l|l|l|l|l}
\hline & Overall & $\begin{array}{l}\text { Overall } \\
\text { 26 devel- } \\
\text { opment } \\
\text { index, } \\
\text { 26 devel- } \\
\text { opmentry } \\
\text { index } \\
\text { based } \\
\text { on six } \\
\text { dimen- } \\
\text { sions }\end{array}$ & $\begin{array}{l}\text { UNDP } \\
\text { democ- } \\
\text { racy }\end{array}$ & $\begin{array}{l}\text { UNDP } \\
\text { eco- } \\
\text { nomic } \\
\text { growth }\end{array}$ & $\begin{array}{l}\text { UNDP } \\
\text { gender }\end{array}$ & $\begin{array}{l}\text { UNDP } \\
\text { human } \\
\text { develop- } \\
\text { ment }\end{array}$ & $\begin{array}{l}\text { UNDP } \\
\text { R\&D }\end{array}$ & $\begin{array}{l}\text { UNDP } \\
\text { social } \\
\text { cohesion }\end{array}$ \\
\hline United States & 1.069 & 1.294 & 0.516 & -0.123 & 0.583 & 0.281 & 3.722 & -0.595 \\
\hline Norway & 1.264 & 1.356 & 0.706 & 0.658 & 1.884 & 0.001 & 1.613 & 0.570 \\
\hline Netherlands & 1.409 & 1.369 & 1.748 & -0.627 & 0.837 & 0.439 & 1.688 & 0.680 \\
\hline Costa Rica & 1.949 & 1.377 & 1.930 & -0.075 & 1.024 & 1.670 & -0.460 & 0.084 \\
\hline Jamaica & 1.687 & 1.401 & 1.703 & -2.057 & 1.210 & 1.780 & 0.516 & 0.191 \\
\hline Finland & 1.544 & 1.509 & 1.364 & -0.531 & 1.911 & 0.196 & 2.312 & 0.433 \\
\hline Sri Lanka & 2.083 & 1.709 & 1.261 & 0.095 & 1.474 & 1.699 & 0.127 & 0.549 \\
\hline Sweden & 1.817 & 1.838 & 1.616 & -0.120 & 1.656 & 0.273 & 3.077 & 0.519 \\
\hline Philippines & 2.452 & 1.871 & 1.324 & -1.188 & 2.119 & 1.745 & 1.295 & 0.239 \\
\hline
\end{tabular}

Appendix Table 3

Rankings: Global Smart Development (Members of the European Union are printed in bold letters)

\begin{tabular}{l|l|l|l|l|l|l|l|l}
\hline & $\begin{array}{l}\text { 26 } \\
\text { develop- } \\
\text { ment } \\
\text { index }\end{array}$ & $\begin{array}{l}\text { 26 } \\
\text { develop- } \\
\text { indent } \\
\text { based } \\
\text { on six } \\
\text { dimen- } \\
\text { sions }\end{array}$ & $\begin{array}{l}\text { Democ- } \\
\text { racy }\end{array}$ & $\begin{array}{l}\text { Eco- } \\
\text { nomic } \\
\text { growth }\end{array}$ & Gender & $\begin{array}{l}\text { Human } \\
\text { develop- } \\
\text { ment }\end{array}$ & R\&D & $\begin{array}{l}\text { Social } \\
\text { cohesion }\end{array}$ \\
\hline Philippines & 1 & 1 & 11 & 126 & 1 & 2 & 13 & 69 \\
\hline Sri Lanka & 2 & 3 & 14 & 63 & 9 & 4 & 60 & 37 \\
\hline Costa Rica & 3 & 6 & 1 & 76 & 18 & 5 & 101 & 85 \\
\hline Sweden & $\mathbf{4}$ & $\mathbf{2}$ & $\mathbf{5}$ & $\mathbf{8 1}$ & $\mathbf{6}$ & $\mathbf{6 1}$ & $\mathbf{2}$ & $\mathbf{3 8}$ \\
\hline Jamaica & 5 & 5 & 3 & 135 & 14 & 1 & 30 & 75 \\
\hline $\begin{array}{l}\text { Dominican } \\
\text { Republic }\end{array}$ & 6 & 19 & 16 & 89 & 20 & 7 & 36 & 123 \\
\hline Finland & $\mathbf{7}$ & $\mathbf{4}$ & $\mathbf{9}$ & $\mathbf{1 0 3}$ & $\mathbf{3}$ & $\mathbf{6 5}$ & $\mathbf{4}$ & $\mathbf{4 2}$ \\
\hline Peru & 8 & 13 & 28 & 29 & 28 & 18 & 25 & 108 \\
\hline Netherlands & $\mathbf{9}$ & $\mathbf{7}$ & $\mathbf{2}$ & $\mathbf{1 0 8}$ & $\mathbf{2 4}$ & $\mathbf{4 8}$ & $\mathbf{7}$ & $\mathbf{2 0}$ \\
\hline $\begin{array}{l}\text { Trinidad and } \\
\text { Tobago }\end{array}$ & 10 & 24 & 17 & 55 & 11 & 34 & 116 & 59 \\
\hline Norway & 11 & 8 & 37 & 33 & 4 & 81 & 8 & 36 \\
\hline Chile & 12 & 28 & 4 & 23 & 66 & 38 & 67 & 104 \\
\hline Switzerland & 13 & 11 & 12 & 90 & 33 & 57 & 9 & 31 \\
\hline & & & & & & & & \\
\hline
\end{tabular}




\begin{tabular}{|c|c|c|c|c|c|c|c|c|}
\hline Country & $\begin{array}{l}26 \\
\text { develop- } \\
\text { ment } \\
\text { index }\end{array}$ & \begin{tabular}{|l|}
26 \\
develop- \\
ment \\
index, \\
based \\
on six \\
dimen- \\
sions \\
\end{tabular} & $\begin{array}{l}\text { Democ- } \\
\text { racy }\end{array}$ & $\begin{array}{l}\text { Eco- } \\
\text { nomic } \\
\text { growth }\end{array}$ & Gender & $\begin{array}{l}\text { Human } \\
\text { develop- } \\
\text { ment }\end{array}$ & R\&D & $\begin{array}{l}\text { Social } \\
\text { cohesion }\end{array}$ \\
\hline Germany & 14 & 20 & 10 & 122 & 21 & 52 & 12 & 56 \\
\hline El Salvador & 15 & 36 & 31 & 118 & 29 & 12 & 63 & 112 \\
\hline United States & 16 & 9 & 46 & 82 & 38 & 58 & 1 & 114 \\
\hline Indonesia & 17 & 14 & 68 & 84 & 37 & 8 & 27 & 61 \\
\hline New Zealand & 18 & 10 & 39 & 41 & 16 & 92 & 3 & 86 \\
\hline Moldova & 19 & 18 & 34 & 139 & 13 & 10 & 19 & 26 \\
\hline Argentina & 20 & 31 & 47 & 111 & 19 & 19 & 21 & 111 \\
\hline India & 21 & 15 & 6 & 18 & 112 & 33 & 31 & 25 \\
\hline Cuba & 22 & 21 & 124 & 48 & 12 & 3 & 46 & 6 \\
\hline Malawi & 23 & 29 & 13 & 30 & 27 & 109 & 34 & 96 \\
\hline Vietnam & 24 & 12 & 106 & 22 & 32 & 6 & 64 & 11 \\
\hline Colombia & 25 & 60 & 76 & 113 & 34 & 9 & 54 & 124 \\
\hline Bangladesh & 26 & 16 & 45 & 37 & 80 & 27 & 24 & 17 \\
\hline Honduras & 27 & 44 & 53 & 95 & 36 & 25 & 83 & 94 \\
\hline Austria & 28 & 23 & 19 & 69 & 56 & 62 & 11 & 23 \\
\hline Denmark & 29 & 30 & 29 & 66 & 31 & 88 & 16 & 81 \\
\hline $\begin{array}{l}\text { United } \\
\text { Kingdom }\end{array}$ & 30 & 25 & 25 & 80 & 47 & 85 & 6 & 54 \\
\hline Panama & 31 & 55 & 49 & 11 & 54 & 43 & 95 & 117 \\
\hline Tajikistan & 32 & 22 & 86 & 132 & 15 & 17 & 20 & 8 \\
\hline Thailand & 33 & 26 & 26 & 115 & 48 & 39 & 37 & 10 \\
\hline Nicaragua & 34 & 41 & 56 & 97 & 23 & 32 & 103 & 43 \\
\hline Guatemala & 35 & 48 & 52 & 104 & 69 & 11 & 86 & 99 \\
\hline Belgium & 36 & 33 & 33 & 75 & 45 & 72 & 15 & 60 \\
\hline Nepal & 37 & 38 & 24 & 86 & 84 & 41 & 41 & 88 \\
\hline South Africa & 38 & 80 & 15 & 101 & 2 & 119 & 78 & 125 \\
\hline France & 39 & 37 & 32 & 65 & 41 & 71 & 23 & 63 \\
\hline Kyrgyzstan & 40 & 17 & 93 & 119 & 8 & 30 & 10 & 41 \\
\hline Madagascar & 41 & 43 & 8 & 131 & 17 & 104 & 77 & 45 \\
\hline Canada & 42 & 35 & 38 & 34 & 55 & 87 & 17 & 83 \\
\hline Bhutan & 43 & 27 & 61 & 6 & $\mathrm{xx}$ & 40 & 76 & 18 \\
\hline Australia & 44 & 34 & 43 & 32 & 50 & 78 & 18 & 90 \\
\hline Ecuador & 45 & 76 & 82 & 116 & 25 & 23 & 124 & 107 \\
\hline
\end{tabular}




\begin{tabular}{|c|c|c|c|c|c|c|c|c|}
\hline Country & \begin{tabular}{|l}
26 \\
develop- \\
ment \\
index
\end{tabular} & \begin{tabular}{|l}
26 \\
develop- \\
ment \\
index, \\
based \\
on six \\
dimen- \\
sions
\end{tabular} & $\begin{array}{l}\text { Democ- } \\
\text { racy }\end{array}$ & $\begin{array}{l}\text { Eco- } \\
\text { nomic } \\
\text { growth }\end{array}$ & Gender & $\begin{array}{l}\text { Human } \\
\text { develop- } \\
\text { ment }\end{array}$ & R\&D & $\begin{array}{l}\text { Social } \\
\text { cohesion }\end{array}$ \\
\hline Mozambique & 46 & 32 & 22 & 36 & 5 & 128 & 70 & 16 \\
\hline Tunisia & 47 & 47 & 80 & 24 & 85 & 15 & 55 & 103 \\
\hline Morocco & 48 & 39 & 72 & 45 & 96 & 13 & 50 & 84 \\
\hline Ghana & 49 & 49 & 20 & 21 & 49 & 106 & 94 & 87 \\
\hline Brazil & 50 & 74 & 50 & 93 & 68 & 31 & 93 & 120 \\
\hline Senegal & 51 & 45 & 18 & 62 & 58 & 102 & 89 & 33 \\
\hline Belize & 52 & 82 & 60 & 52 & 74 & 35 & 127 & 113 \\
\hline China & 53 & 40 & 122 & 1 & 81 & 22 & 81 & 51 \\
\hline Georgia & 54 & 42 & 66 & 112 & 97 & 14 & 14 & 101 \\
\hline Ireland & 55 & 57 & 40 & 114 & 42 & 86 & 28 & 57 \\
\hline Iceland & 56 & 63 & 30 & 125 & 7 & 79 & 130 & 49 \\
\hline Bulgaria & 57 & 51 & 54 & 121 & 40 & 50 & 53 & 48 \\
\hline Guyana & 58 & 81 & 73 & 15 & 22 & 98 & 122 & 115 \\
\hline Slovakia & 59 & 65 & 51 & 59 & 65 & 56 & 107 & 68 \\
\hline Hungary & 60 & 52 & 21 & 99 & 72 & 80 & 57 & 35 \\
\hline Poland & 61 & 59 & 65 & 27 & 67 & 74 & 51 & 76 \\
\hline Jordan & 62 & 50 & 99 & 39 & 87 & 21 & 32 & 92 \\
\hline Cambodia & 63 & 54 & 77 & 91 & 59 & 93 & 62 & 13 \\
\hline Tanzania & 64 & 61 & 48 & 20 & 35 & 124 & 85 & 32 \\
\hline Israel & 65 & 46 & 84 & 57 & 83 & 70 & 5 & 74 \\
\hline Spain & 66 & 64 & 57 & 67 & 52 & 77 & 59 & 80 \\
\hline Bolivia & 67 & 92 & 62 & 50 & 76 & 76 & 35 & 126 \\
\hline Portugal & 68 & 73 & 23 & 98 & 73 & 89 & 87 & 78 \\
\hline Slovenia & 69 & 53 & 41 & 46 & 82 & 69 & 74 & 21 \\
\hline Albania & 70 & 83 & 88 & 47 & 94 & 24 & 102 & 118 \\
\hline Croatia & 71 & 77 & 81 & 105 & 57 & 46 & 110 & 62 \\
\hline Japan & 72 & 56 & 27 & 107 & 98 & 66 & 33 & 14 \\
\hline Malaysia & 73 & 69 & 78 & 106 & 95 & 26 & 79 & 53 \\
\hline Lithuania & 74 & 66 & 42 & 138 & 39 & 63 & 42 & 22 \\
\hline Uzbekistan & 75 & 62 & 135 & 4 & 26 & 55 & 115 & 2 \\
\hline Armenia & 76 & 67 & 74 & 133 & 105 & 16 & 40 & 67 \\
\hline Benin & 77 & 58 & 7 & 77 & 109 & 114 & 66 & 7 \\
\hline Italy & 78 & 71 & 64 & 102 & 93 & $\mid 67$ & 22 & 50 \\
\hline
\end{tabular}




\begin{tabular}{|c|c|c|c|c|c|c|c|c|}
\hline Country & $\begin{array}{l}26 \\
\text { develop- } \\
\text { ment } \\
\text { index }\end{array}$ & \begin{tabular}{|l|}
26 \\
develop- \\
ment \\
index, \\
based \\
on six \\
dimen- \\
sions \\
\end{tabular} & $\begin{array}{l}\text { Democ- } \\
\text { racy }\end{array}$ & $\begin{array}{l}\text { Eco- } \\
\text { nomic } \\
\text { growth }\end{array}$ & Gender & $\begin{array}{l}\text { Human } \\
\text { develop- } \\
\text { ment }\end{array}$ & R\&D & $\begin{array}{l}\text { Social } \\
\text { cohesion }\end{array}$ \\
\hline Luxembourg & 79 & 99 & 59 & 109 & 62 & 37 & 139 & 116 \\
\hline Mongolia & 80 & 88 & 55 & 8 & 61 & 116 & 108 & 106 \\
\hline Romania & 81 & 78 & 79 & 123 & 70 & 59 & 98 & 27 \\
\hline Cyprus & 82 & 90 & 58 & 16 & 108 & 64 & 135 & 55 \\
\hline Uganda & 83 & 70 & 112 & 12 & 10 & 122 & 91 & 30 \\
\hline Algeria & 84 & 84 & 116 & 54 & 92 & 28 & 75 & 110 \\
\hline Latvia & 85 & 75 & 70 & 137 & 30 & 90 & 26 & 40 \\
\hline Pakistan & 86 & 72 & 69 & 94 & 118 & 42 & 61 & 24 \\
\hline Zambia & 87 & 85 & 36 & 79 & 71 & 129 & 48 & 102 \\
\hline Kenya & 88 & 79 & 89 & 85 & 51 & 115 & 72 & 39 \\
\hline Mexico & 89 & 97 & 94 & 100 & 88 & 49 & 123 & 58 \\
\hline Egypt & 90 & 89 & 117 & 43 & 113 & 20 & 109 & 77 \\
\hline Venezuela & 91 & 94 & 109 & 127 & 60 & 45 & 96 & 79 \\
\hline $\begin{array}{l}\text { Korea (Republic } \\
\text { of) }\end{array}$ & 92 & 96 & 85 & 58 & 114 & 53 & 125 & 9 \\
\hline Malta & 93 & 101 & 107 & 53 & 102 & 47 & 126 & 71 \\
\hline Syria & 94 & 103 & 129 & 44 & 100 & 29 & 114 & 109 \\
\hline Laos & 95 & 68 & 119 & 25 & $\mathrm{xx}$ & 44 & 80 & 5 \\
\hline Congo & 96 & 126 & 71 & 96 & $\mathrm{xx}$ & 95 & 39 & $\mathrm{Xx}$ \\
\hline Uruguay & 97 & 108 & 90 & 13 & 90 & 107 & 132 & 100 \\
\hline Paraguay & 98 & 117 & 121 & 72 & 53 & 84 & 128 & 121 \\
\hline Czech Republic & 99 & 102 & 87 & 71 & 91 & 100 & 131 & 29 \\
\hline Ukraine & 100 & 93 & 102 & 136 & 63 & 75 & 44 & 34 \\
\hline Greece & 101 & 104 & 98 & 35 & 103 & 97 & 118 & 82 \\
\hline Ethiopia & 102 & 91 & 83 & 9 & 104 & 130 & 92 & 19 \\
\hline Singapore & 103 & 100 & 110 & 130 & 107 & 51 & 58 & 47 \\
\hline Mauritania & 104 & 115 & 111 & 40 & 86 & 110 & 113 & 119 \\
\hline Angola & 105 & 127 & 101 & 68 & 43 & 132 & 68 & $\mathrm{Xx}$ \\
\hline Mali & 106 & 107 & 35 & 28 & 111 & 133 & 105 & 98 \\
\hline Djibouti & 107 & 137 & 67 & 42 & $\mathrm{xx}$ & 113 & 99 & 133 \\
\hline Yemen & 108 & 98 & 96 & 19 & 122 & 68 & 69 & 89 \\
\hline Haiti & 109 & 111 & 97 & 134 & $\mathrm{xx}$ & 54 & 38 & 122 \\
\hline Myanmar & 110 & 87 & 131 & 14 & $x x$ & 60 & 45 & 72 \\
\hline
\end{tabular}




\begin{tabular}{|c|c|c|c|c|c|c|c|c|}
\hline Country & $\begin{array}{l}26 \\
\text { develop- } \\
\text { ment } \\
\text { index }\end{array}$ & \begin{tabular}{|l}
26 \\
develop- \\
ment \\
index, \\
based \\
on six \\
dimen- \\
sions \\
\end{tabular} & $\begin{array}{l}\text { Democ- } \\
\text { racy }\end{array}$ & $\begin{array}{l}\text { Eco- } \\
\text { nomic } \\
\text { growth }\end{array}$ & Gender & $\begin{array}{l}\text { Human } \\
\text { develop- } \\
\text { ment }\end{array}$ & R\&D & $\begin{array}{l}\text { Social } \\
\text { cohesion }\end{array}$ \\
\hline $\begin{array}{l}\text { Congo } \\
\text { (Democratic } \\
\text { Republic of the) }\end{array}$ & 111 & 132 & 108 & 5 & $\mathrm{xx}$ & 121 & 43 & $X x$ \\
\hline Azerbaijan & 112 & 95 & 132 & 2 & 110 & 94 & 84 & 95 \\
\hline Togo & 113 & 133 & 75 & 128 & $\mathrm{xx}$ & 103 & 47 & $\mathrm{Xx}$ \\
\hline Iran & 114 & 120 & 126 & 17 & 116 & 83 & 129 & 97 \\
\hline Saudi Arabia & 115 & 114 & 128 & 78 & 121 & 36 & 100 & 64 \\
\hline Botswana & 116 & 129 & 44 & 3 & 99 & 140 & 136 & 128 \\
\hline Nigeria & 117 & 109 & 115 & 88 & 79 & 125 & 88 & 44 \\
\hline Cameroon & 118 & 113 & 120 & 92 & 89 & 120 & 82 & 73 \\
\hline Rwanda & 119 & 86 & 92 & 38 & $\mathrm{xx}$ & 123 & 52 & 3 \\
\hline Turkey & 120 & 121 & 113 & 117 & 119 & 73 & 117 & 91 \\
\hline Namibia & 121 & 136 & 91 & 49 & 64 & 139 & 137 & 132 \\
\hline Guinea & 122 & 106 & 103 & 61 & $\mathrm{xx}$ & 117 & 90 & 28 \\
\hline Lebanon & 123 & 131 & 134 & 10 & $\mathrm{xx}$ & 101 & 71 & $\mathrm{Xx}$ \\
\hline Estonia & 124 & 122 & 114 & 120 & 78 & 118 & 119 & 66 \\
\hline Burkina Faso & 125 & 116 & 104 & 26 & 106 & 137 & 120 & 12 \\
\hline Russia & 126 & 112 & 130 & 124 & 75 & 108 & 29 & 46 \\
\hline Kazakhstan & 127 & 118 & 138 & 73 & 46 & 112 & 111 & 52 \\
\hline Macedonia & 128 & 134 & 127 & 70 & 101 & 111 & 133 & 127 \\
\hline Sierra Leone & 129 & 128 & 63 & 74 & $\mathrm{xx}$ & 135 & 49 & 129 \\
\hline Belarus & 130 & 105 & 139 & 83 & 44 & 105 & 65 & 4 \\
\hline $\begin{array}{l}\text { Hong Kong, } \\
\text { China (SAR) }\end{array}$ & 131 & 119 & 133 & 64 & $\mathrm{xx}$ & 91 & 97 & 70 \\
\hline Burundi & 132 & 110 & 95 & 110 & $\mathrm{xx}$ & 126 & 56 & 15 \\
\hline Zimbabwe & 133 & 125 & 118 & 140 & 77 & 134 & 73 & 65 \\
\hline Chad & 134 & 123 & 125 & 60 & 117 & 131 & 112 & 1 \\
\hline Kuwait & 135 & 138 & 137 & 31 & 115 & 99 & 138 & $\mathrm{Xx}$ \\
\hline Niger & 136 & 124 & 100 & 51 & $\mathrm{xx}$ & 136 & 106 & 93 \\
\hline $\begin{array}{l}\text { United Arab } \\
\text { Emirates }\end{array}$ & 137 & 130 & 136 & 56 & 120 & 82 & 140 & 105 \\
\hline $\begin{array}{l}\text { Central African } \\
\text { Republic, }\end{array}$ & 138 & 135 & 105 & 87 & $\mathrm{xx}$ & 138 & 104 & 130 \\
\hline $\begin{array}{l}\text { Bosnia and } \\
\text { Herzegovina }\end{array}$ & 139 & 139 & 123 & 129 & $\mathrm{xx}$ & 96 & 134 & 131 \\
\hline
\end{tabular}




\begin{tabular}{l|l|l|l|l|l|l|l|l}
\hline & & $\begin{array}{l}\text { 26 } \\
\text { develop- } \\
\text { ment } \\
\text { index, } \\
\text { Cosed } \\
\text { develop- } \\
\text { on six } \\
\text { index } \\
\text { dimen- } \\
\text { sions }\end{array}$ & $\begin{array}{l}\text { Democ- } \\
\text { racy }\end{array}$ & $\begin{array}{l}\text { Eco- } \\
\text { nomic } \\
\text { growth }\end{array}$ & Gender & $\begin{array}{l}\text { Human } \\
\text { develop- } \\
\text { ment }\end{array}$ & R\&D & $\begin{array}{l}\text { Social } \\
\text { cohesion }\end{array}$ \\
\hline Sudan & 140 & 140 & 140 & 7 & $\mathrm{xx}$ & 127 & 121 & $\mathrm{Xx}$ \\
\hline
\end{tabular}

\section{References}

Acemoğlu, D. (2003). “Cross-Country Inequality Trends,” Economic Journal, 113: 121-149.

-----, (2005). "Politics and Economics in Weak and Strong States," Journal of Monetary Economics, Swiss National Bank, Special Issue, 52: 1199-1226.

------, (2009). The Crisis of 2008: Structural Lessons for and from Economics. As yet unpublished working paper, available [online] at: http://econ-www.mit.edu/faculty/acemoglu/other

-----, (2010a). "Theory, General Equilibrium, Political Economy and Empirics in Development Economics," Journal of Economic Perspectives, 24(2): 17-32.

-----, (2010b). “When Does Labor Scarcity Encourage Innovation?” Journal of Political Economy, 118(6): 1037-1078.

Acemoğlu, D. and Dell, M. (2010). "Productivity Differences between and within Countries," American Economic Journal: Macroeconomics, 2(1): 169-88.

Acemoğlu, D. and Robinson, J. (2000). "Why Did the West Extend the Franchise Democracy, Inequality and Growth in Historical Perspective," Quarterly Journal of Economics, 115: 1167-1199.

------, (2001). “Inefficient Redistribution,” American Political Science Review, 95: 649-61.

------, (2006). “Economic Backwardness in Political Perspective," American Political Science Review, 100: $115-131$.

Acemoğlu, D., Johnson, S., and Robinson, J. (2001). "The Colonial Origins of Comparative Development: An Empirical Investigation," American Economic Review, 91: 1369-1401.

------, (2002). "Reversal of Fortune: Geography and Institutions in the Making of the Modern World Income Distribution," Quarterly Journal of Economics, 117: 1231-1294.

-----, (2005). "The Rise of Europe: Atlantic Trade, Institutional Change and Growth," American Economic Review, (June) 95: 546-579.

Acemoğlu, D., Johnson, S., Robinson, J., and Yared, P. (2008). “Income and Democracy,” American Economic Review, 98: 808-842.

Acosta, P., Calderon, C., Fajnzylber, P. et al. (2008). "What Is the Impact of International Remittances on Poverty and Inequality in Latin America?" World Development, 36(1): 89-114.

Addison, T. and Heshmati, A. (2004). "The New Global Determinants of FDI to Developing Countries," Research in Banking and Finance, 4: 151-186.

Afxentiou, P.C. (1990a). "Basic Needs - A Survey of the Literature," Revue Canadienne d'Etudes du Developpement - Canadian Journal of Development Studies, 11(2): 241-257. 
-----, (1990b). "The Rhetoric and Substance of Basic Needs," South African Journal of Economics, 58(1): 78-87.

Aghion, Ph. and Howitt, P. (1992). "A Model of Growth through Creative Destruction," Econometrica, 60(2): 323-351.

Agosin, M. and Machado, R. (2005). "Foreign Investment in Developing Countries: Does it Crowd in Domestic Investment?" Oxford Development Studies, 33(2): 149-162.

Alesina, A. and Perotti, R. (1994). "The Political Economy of Growth. A Critical Survey of the Recent Literature," World Bank Economic Review, 8(3): 351-371.

Alesina, A., Spolaore, E., and Wacziarg, R. (2000). Economic Integration and Political Disintegration," American Economic Review, 90(5): 1276-1296.

Allsopp, C. and Artis, M.J. (2003). “The Assessment: EMU, Four Years On,” Oxford Review of Economic Policy, 19(1): 1-29.

Amin, S. (1973). Le Developpement Inegal. Essai sur les Formations Sociales du Capitalisme Peripherique (Unequal Development: An Essay on the Social Formations of Peripheral Capitalism). Paris: Editions de Minuit.

-----, (1976). Unequal Development: An Essay on the Social Formations of Peripheral Capitalism. New York: Monthly Review Press.

-----, (1980). "The Class Structure of the Contemporary Imperialist System," Monthly Review, 31(8): 9-26.

-----, (1984). "Was kommt nach der Neuen Internationalen Wirtschaftsordnung? Die Zukunft der Weltwirtschaft" in H. Fischer and P. Jankowitsch (eds.) Rote Markierungen International: 89-110. Vienna: Europaverlag. [English version available under the same title from Amin, S. (1982). "After the New International Economic Order: The Future of International Economic Relations," Journal of Contemporary Asia, 12(4)].

------, (1989). Eurocentrism. R. Moore (trans.). New York: Monthly Review Press.

------, (1992). Empire of Chaos. New York: Monthly Review Press.

-----, (1994a). “The Future of Global Polarization,” Review (Fernand Braudel Center, USA), 17(3): 337-347.

, (1994b). "Die Neue Kapitalistische Globalisierung - die Herrschaft des Chaos (The New Capitalist Globalization - The Rule of Chaos)," Starnberger Forschungsberichte, 3(4): 7-26. [English version available from Links. International Journal of Socialist Renewal "The New Capitalist Globalisation: Problems and Perspectives." Retrievable from http://links.org.au/node/193 ]

------, (1994c). Re-reading the Postwar Period: An Intellectual Itinerary. M.Wolfers (trans.).

New York: Monthly Review Press.

-----, (1997a). Capitalism in the Age of Globalization. London, England: Zed Books.

-----, (1997b). Die Zukunft des Weltsystems. Herausforderungen der Globalisierung. Herausgegeben und aus dem Franzoesischen Uebersetzt von Joachim Wilke. Hamburg: VSA. ["The Future of the World System. The Challenges of Globalization," various editions in French, Spanish, Chinese, Turkish; available; English version available only as an abridged essay: Amin, S. and Luckin D. (1996)."The Challenge of Globalization," Review of International Political Economy, 3(2): 216-259]. 
Amin, S., Arrighi, G., Frank, A.G., and Wallerstein, I. (1982). Dynamics of Global Crisis. Basingstoke: Palgrave Macmillan.

Amuedo-Dorantes, C. and Pozo, S. (2004). Workers' Remittances and the Real Exchange Rate: A Paradox of Gifts," World Development, 32(8): 1407-1417.

Anand, S. and Ravallion, M. (1993). "Human Development in Poor Countries. On the Role of Private Incomes and Public Services," Journal of Economic Perspective, 7(1): 133-150.

Angelsen, A. and Kaimowitz, D. (1999). Rethinking the Causes of Deforestation: Lessons from Economic Models," World Bank Research Observer, 14(1): 73-98.

Anson, J. (1988). "Mortality and Living Conditions. Relative Mortality Levels and Their Relation to the Physical Quality of Life in Urban Populations," Social Science and Medicine, 27(9): 901-910.

------, (1991). “Demographic Indexes as Social Indicators," Environment and Planning, 23(3): 433-446.

-----, (1995). The Long 20th Century. Money, Power, and the Origins of Our Times. London, New York: Verso.

Auvinen, J. and Nafziger, E.W. (1999). "The Sources of Humanitarian Emergencies," Journal of Conflict Resolution, 43(3): 267-290.

Bandelji, N. (2009). "The Global Economy as Instituted Process: The Case of Central and Eastern Europe," American Sociological Review, 74(1): 128-149.

Barro, R.J. (2000). "Inequality and Growth in a Panel of Countries," Journal of Economic Growth, 5(1): 5-32.

-----, (2003). "Economic Growth in a Cross Section of Countries," International Library of Critical Writings in Economics, 159(1): 350-386.

Barro, R.J. and Sala-i-Martin, X. (2003). Economic Growth (Second edition). Cambridge, MA: MIT Press.

Beer, L. (1999). "Income Inequality and Transnational Corporate Penetration," Journal of World Systems Research, 5(1): 1-25.

Biswas, B. and Ram, R. (1986). "Military Expenditures and Economic Growth in Less-developed Countries. An Augmented Model and Further Evidence," Economic Development and Cultural Change, 34(2): 361-372.

Blankenau, W.F. and Simpson, N.B. (2004). "Public Education Expenditures and Growth," Journal of Development Economics, 73(2): 583-605.

Bobróvnikov, A.V. (2004). Makrocikly v Ekonomike stran Latinskoj Ameriki. (Macrocycles in the Economies of Latin American Countries). Moskva: Inst. Latinskoj Ameriki.

Bornschier, V. (1976). Wachstum, Konzentration und Multinationalisierung von Industrieunternehmen(Growth, Concentration and Multinationalization of Industrial Enterprises). Frauenfeld, Stuttgart: Huber.

------, (1980a). "Multinational Corporations, Economic Policy and National Development in the World System," International Social Science Journal, 32(1): 158-172.

------, (1980b). Multinationale Konzerne, Wirtschaftspolitik und Nationale Entwicklung im Weltsystem. (Multinational Enterprises, Economic Policy and National Development in the World System). Mit Beiträgen von Thanh-Huyen Ballmer-Cao [et al.]. Frankfurt/Main; New York: Campus. 
------, (1981). "Dependent Industrialization in the World Economy: Some Comments and Results Concerning a Recent Debate," The Journal of Conflict Resolution, 25(3): 371-400.

-----, (1982). "The World Economy in the World System. Structure Dependence and Change," International Social Science Journal, 34(1): 38-59.

------, (1983). "World Economy, Level Development and Income Distribution: An Integration of Different Approaches to the Explanation of Income Inequality," World Development, 11(1): 11-20.

------, (1996). Western Society in Transition. New Brunswick, NJ: Transaction Publishers.

-----, (2002). "Changing Income Inequality in the Second Half of the 20th Century: Preliminary Findings and Propositions for Explanations," Journal of World-Systems Research, (Winter),1: 100127. Available [online] at: http://jwsr.ucr.edu/index.phpVIII, 1, Winter: 100-127.

Bornschier, V. and Ballmer-Cao, T.H. (1979). "Income Inequality: A Cross-national Study of the Relationships between MNC-Penetration, Dimensions of the Power Structure and Income Distribution," American Sociological Review, 44(3): 438-506.

Bornschier, V. and Chase-Dunn, C.K. (1985). Transnational Corporations and Underdevelopment. NY, NY: Praeger.

Bornschier, V., Chase-Dunn, C.K., and Rubinson, R. (1978). "Cross-national Evidence of the Effects of Foreign Investment and Aid on Economic Growth and Inequality: A Survey of Findings and a Reanalysis," American Journal of Sociology, 84(3): 651-683.

Bovenberg, A.L. and van Ewijk, C. (1997). "Progressive Taxes, Equity, and Human Capital Accumulation in an Endogenous Growth Model with Overlapping Generations," Journal of Public Economics, 64(2): 153-179.

Brand, U. (2005). Gegen-Hegemonie. Perspektiven Globalisierungskritischer Strategien (CounterHegemony. Perspectives of Globalization-critical Strategies). Hamburg: VSA.

Brand, U. and Goerg, Ch. (2003). Postfordistische Naturverhältnisse: Konflikte um Genetische Ressourcen und die Internationalisierung des Staate (Post-fordist Relationships of Nature. Conflicts about Genetical Resources and the Internationalization of the State). Muenster: Westfaelisches Dampfboot.

Brand, U. and Raza, W. (eds.) (2003). Fit fur den Postfordismus?: Theoretisch-politische Perspektiven des Regulationsansatzes (Fit for Post-fordism? Theoretical-political Perspectives of the Regulation Approach) . Muenster: Westfaelisches Dampfboot.

Brand, U. et al. (eds.) 2001. Nichtregierungsorganisationen in der Transformation des Staates (NGOs in the Transformation of the State). Muenster: Westfaelisches Dampfboot.

Brand, U. et al. (2000). Global Governance: Alternative zur Neoliberalen Globalisierung? Muenster: Westfaelisches Dampfboot. (Global Governance: An Alternative to Neo-liberal Globalization?)

------, (2008). Conflicts in Environmental Regulation and the Internationalisation of the State: Contested Terrains. London: Routledge.

Burckett, P. (1999). Marx and Nature: A Red and Green Perspective. New York: St. Martin's Press.

Buti, F., Franco, D., and Ongena, H. (1998). "Fiscal Discipline and Flexibility in EMU: The Implementation of the Stability and Growth Pact," Oxford Review of Economic Policy, 14(3): 81-97.

Cardoso, F.H. (1977). "El Consumo de la Teoría de la Dependencia en los Estados Unidos" El Trimestre Economico, 173(44/1): 33-52. [Available in English under the same title: "The Consumption of Dependency Theory in the United States," Latin American Research Review, 12( 3): 7-24] 
-, (1979). Development under Fire. Mexico D. F.: Instituto Latinoamericano de Estudios Transnacionales, DEE/D/24 i, Mayo (Mexico 20 D.F., Apartado 85-025.

Cardoso, F.H. and Faletto, E. (1971). Dependencia y Desarrollo en América Latina. Mexico D. F.: Editorial Siglo XXI. [English version available under the title: Dependency and Development in Latin America. Berkeley: University of California Press, 1979]

Carruthers, J.I. and Ulfarsson, G. (2007). "Does 'Smart Growth' Matter to Public Finance?” Urban Studies, 45(9): 1791-1823.

CEPAL/ECLAC (2002). Globalización y Desarrollo(Globalization and Development). United Nations Economic Commission for Latin America (Santiago de Chile) Available [online] at: http://www.eclac. cl/cgi-bin/getProd. asp?xml=/publicaciones/xml/6/10026/P10026. xml\&xsl=/tpl/p9f. xsl\&base=/ MDG/tpl/top-bottom. xsl. (English version available at http://www.eclac.cl/cgi-bin/getProd.asp?xml=/ publicaciones/xml/0/10030/P10030.xml

Chase-Dunn, C.K. (1975). "The Effects of International Economic Dependence on Development and Inequality: A Cross- national Study," American Sociological Review, 40(4): 720-738.

Chen, X.M. (1995). "The Evolution of Free Economic Zones and the Recent Development of Crossnational Growth Zones," International Journal of Urban and Regional Research, 19(4): 593-616.

Cheng W.Y. (1989). "Testing the Food-First Hypothesis. A Cross-national Study of Dependency, Sectoral Growth and Food-Intake in Less Developed Countries," World Development, 17(1): 17-27.

Coleman, J.S. (196). Education and Political Development. Princeton: Princeton University Press.

Constant, A., Gataullina, L., Zimmermann, K.F., and Zimmermann, L. (2006). Clash of Cultures: Muslims and Christians in the Ethnosizing Process. German Institute for Economic Research, Discussion Paper 628, Berlin, October 2006. Available [online] at: http://ideas.repec.org/p/diw/diwwpp/dp628.html.

Cook, C.J. (1995). Savings Rates and Income Distribution. Further Evidence from LDCs," Applied Economics, 27(1): 71-82.

Crenshaw, E. and Robison, K. (2010). "Socio-Demographic Determinants of Economic Growth: AgeStructure, Preindustrial Heritage and Sociolinguistic Integration," Social Forces, 88(5): 2217-2240.

Cropper, M.L. and Oates, W.E. (1992). "Environmental Economics - A Survey," Journal of Economic Literature, 30(2): 675-740.

De Haan, J, Lundstrom, S, and Sturm, J.E. (2006). "Market Oriented Institutions and Policies and Economic Growth: A Critical Survey," Journal of Economic Surveys, 20(2): 157-191.

de la Porte, C., Pochet, P., and Room, G. (2001). "Social Benchmarking, Policy Making and New Governance in the EU," Journal of European Social Policy, 11(4): 291-307.

De Soysa, I. and Oneal, J.R. (1999). "Boon or Bane? - Reassessing the Productivity of Foreign Direct Investment," American Sociological Review, 64: 766-782.

De Soysa, I. and Ragnhild, N. ). (2007) "Islam's Bloody Innards? Religion and Political Terror, 19802000," International Studies Quarterly, 51(4): 927-943.

Devezas, T.C. (ed.) (2006). Kondratieff Waves, Warfare and World Security.(Proceedings of the NATO Advanced Research Workshop on The Influence of Chance Events and Socioeconomic Long Waves in the New Arena of Asymmetric Warfare, Covilhã, Portugal, 14-18 February 2005). Amsterdam: IOS Press.

Devezas, T.C. and Corredine, J.T. (2001). "The Biological Determinants of Long-wave Behavior in Socioeconomic Growth and Development," Technological Forecasting and Social Change, 68 (1): 1-57. 
Dick, C. and Jorgenson, A.K. (2010). "Sectoral Foreign Investment and Nitrous Oxide Emissions: A Quantitative Investigation," Society and Natural Resources, 23(1): 71-82.

Dietz, T., Rosa, E.A., and York, R. (2007). Driving the Human Ecological Footprint," Frontiers in Ecology and the Environment, 5(1): 13-18.

------, (2009). "Environmentally Efficient Well-being: Rethinking Sustainability as the Relationship between Human Well-being and Environmental Impact," Human Ecology Review, 16(1): 114-123.

Dinopoulos, E. and Thompson, P. (1999). "Scale Effects in Schumpeterian Models of Economic Growth," Journal of Evolutionary Economics, 9(2): 157-185.

Dixon, W.J. (1987). "Progress in the Provision of Basic Human Needs. Latin America, 1960-1980," Journal of Developing Areas, 21(2): 129-140.

Dixon W.J. and Boswell T. (1996a) "Dependency, Disarticulation, and Denominator Effects: Another Look at Foreign Capital Penetration," American Journal of Sociology, 102(2): 543-562.

-----, (1996b). "Differential Productivity, Negative Externalities, and Foreign Capital Dependency: Reply to Firebaugh," American Journal of Sociology, 102(2): 576-584.

Dixon, W.J. and Moon, B.E. (1986). “The Military Burden and Basic Human Needs,” Journal of Conflict Resolution, 30(4): 660-684.

-----, 1989. "Domestic Political Conflict and Basic Needs Outcomes. An Empirical Assessment," Comparative Political Studies, 22(2): 178-198.

Dollar, D. (1992a). "Growth is Good for the Poor," Journal of Economic Growth, 7(3): 195-225.

------, (1992b). “Outward-oriented Developing Countries Really Do Grow More Rapidly. Evidence from 95 LDCs, 1976-1985," Economic Development and Cultural Change, 40(3): 523-544.

Doucouliagos, H. and Paldam, M. (2008). “Aid Effectiveness on Growth: A Meta Study,” European Journal of Political Economy, 24(1): 1-O24.

Downs, A. (2005). "Smart Growth - Why We Discuss It More Than We Do It?" Journal of the American Planning Association, 71(4): 367-378.

Durlauf, St.N., Kourtellos, A., and Tan, C. M. (2008). “Are Any Growth Theories Robust?” The Economic Journal, 118(1): 329-346.

Dutt, A.K. (1997). "The Pattern of Direct Foreign Investment and Economic Growth," World Development, 25(11): 1925-1936.

Easterlin, R.A. (1995). “Will Raising the Incomes of All Increase the Happiness of All?" Journal of Economic Behavior and Organization, 27(1): 35-47.

-----, (2001). “Income and Happiness: Towards a Unified Theory," Economic Journal, 111(473): 465-484.

Easterly, W. (2000). The Middle Class Consensus and Economic Development. (May 2000. World Bank Policy Research Working Paper No. 2346. Available at: SSRN: http://ssrn. com/abstract=630718 (Data available [online] at:http://www.cgdev.org/doc/expert\%20pages/easterly/easterly_consensusdata. xls in EXCEL-format. The data are also still retrievable by a Google search, using the search profile words easterly consensus data. xls).

------, 2002. Inequality Does Cause Underdevelopment: New Evidence. Center for Global Development, Working Paper 1, January 2002, available [online] at: http://www. cgdev. org/wp/cgd_wp001_rev.pdf. 
Easterly, W. and Levine, R. (1997). “Africa's Growth Tragedy: Policies and Ethnic Divisions," Quarterly Journal of Economics, 112(4): 1203-1250.

Easterly, W. and Schmidthebbel, K. (1993). "Fiscal Deficits and Macroeconomic Performance in Developing Countries," World Bank Research Observer, 8(2): 211-237.

Edwards, S. (1993). "Openness, Trade Liberalization, and Growth in Developing Countries," Journal of Economic Literature, 31(3): 1358-1393.

Egert, B., Drine, I., Lommatzsch, K. et al. (2003). "The Balassa-Samuelson Effect in Central and Eastern Europe: Myth or Reality?” Journal of Comparative Economics, 31(3): 552-572.

Ehrhardt-Martinez, K., Crenshaw, E.M., and Jenkins, J.C. (2002). "Deforestation and the Environmental Kuznets Curve: A Cross-national Investigation of Intervening Mechanisms," Social Science Quarterly, 83(1): 226-243.

Fain, H.D. et al. (1997). "World-System Position, Tropical Climate, National Development, and Infant Mortality: A Cross-national Analysis of 86 Countries," Human Ecology Review, 3: 197-203.

Faria, J.R and Leon-Ledesma, M. (2003). "Testing the Balassa-Samuelson Effect: Implications for Growth and the PPP," Journal of Macroeconomics, 25(2): 241-253.

Feldstein, M. (1994). "Fiscal Policies, Capital Formation, and Capitalism," European Economic Review, 39(3-4): 399-420.

Firebaugh, G. (1992). "Growth Effects of Foreign and Domestic Investment," American Journal of Sociology, 98:105-130.

Firebaugh, G. and Beck, F.D. (1994). "Does Economic Growth Benefit the Masses? Growth, Dependence, and Welfare in the Third World," American Sociological Review, 59: 631-653.

Fosu, A.K. (200). "Inequality and the Impact of Growth on Poverty: Comparative Evidence for SubSaharan Africa," Journal of Development Studies, 45(5): 726-745.

------, (2010a). "The Effect of Income Distribution on the Ability of Growth to Reduce Poverty: Evidence from Rural and Urban African Economies," American Journal of Economics and Sociology, 69(3): 1034-1053.

------, (2010b). "Does Inequality Constrain Poverty Reduction Programs? Evidence from Africa," Journal of Policy Modeling, 32(6): 818-827.

------, (2010c). “Inequality, Income, and Poverty: Comparative Global Evidence,” Social Science Quarterly, 91(5): 1432-1446.

Frank, A.G. (1967). Capitalism and Underdevelopment in Latin America: Historical Studies of Chile and Brazil. New York: Monthly Review Press.

-----, (1998). "ReOrient: Global Economy in the Asian Age. Ewing, USA: University of California Press.

Frankel, J.A. and Romer, D. (1999). "Does Trade Cause Growth?" American Economic Review, 89(3): 379-99.

Frey, B.S. and Stutzer, A. (2002). "What Can Economists Learn from Happiness Research?” Journal of Economic Literature, 40(2): 402-435.

Froebel, F. et al. (1980). The New International Division of Labour: Structural Unemployment in Industrialised Countries and Industrialisation in Developing Countries. Cambridge, New York: Cambridge University Press; Paris: Editions de la Maison des Sciences de lHomme. 
Furtado, C. (1963). The Economic Growth of Brazil: A Survey from Colonial to Modern Times [R.W. de Aguiar and E.C. Drysdale (trans.)]. Berkeley University of California Press.

------, (1964). Development and Underdevelopment [R.W. de Aguiar and E.C. Drysdale (trans.)]. Berkeley: California University Press.

-----, (1976). Economic Development of Latin America: Historical Background and Contemporary Problems [(S. Macedo (trans.)]. Cambridge, New York: Cambridge University Press.

-----, (1983). Accumulation and Development: The Logic of Industrial Civilization [(S. Macedo (trans.)]. Oxford: M. Robertson.

Gallup, J.L.,Sachs, J.D., and Mellinger, A.D. (1999). "Geography and Economic Development," in B. Pleskovic and J.E. Stiglitz (eds.) Annual World Bank Conference on Development Economics 1998. Washington, DC: The World Bank (April). Also published in International Regional Science Review, 22(2): 179-232.

Galtung, J. (1971). “A Structural Theory of Imperialism,” Journal of Peace Research, 8(2): 81-117.

Gine, X. and Townsend, R.M. (2004). "Evaluation of Financial Liberalization: A General Equilibrium Model with Constrained Occupation Choice," Journal of Development Economics, 74(2): 269-307.

Glomm, G. and Ravikumar, B. (1997). "Productive Government Expenditures and Long-run Growth," Journal of Economic Dynamics and Control, 21(1): 183-204.

Goldstein, J.S. (1985). "Basic Human Needs - The Plateau Curve," World Development, 13(5): 595-609.

-----, (1988). Long Cycles: Prosperity and War in the Modern Age. New Haven: Yale University Press.

Gould, E.D. (2002). "Rising Wage Inequality, Comparative Advantage, and the Growing Importance of General Skills in the United States," Journal of Labor Economics, 20(1): 105-147.

Grier, K.B. and Tullock, G. (1989). "An Empirical Analysis of Cross-national Economic Growth," Journal of Monetary Economics, 24(2): 259-76.

Guger A., Marterbauer, M., and Walterskirchen, E. (2006). "Growth Policy in the Spirit of Steindl and Kalecki," Metroeconomica, 57(3): 428-442.

Guger, A., Marterbauer, M. and Walterskirchen, E. (2006). "Zur Aktualität der Politischen Ökonomie von Josef Steindl (On the Relevance of the Political Economy of Josef Steindl)," Kurswechsel, 4: 18-26. available [online] at: http://ewald. walterskirchen. wifo. ac. at/

-----, (2004). Growth Policy in the Spirit of Steindl and Kalecki. WIFO Working papers, 240. Available [online] at: http://ewald. walterskirchen. wifo. ac.at/ .

Gwartney, J.D., Lawson, R.A., and Holcombe, R.G. (1999). "Economic Freedom and the Environment for Growth," Journal of Institutional and Theoretical Economics - Zeitschrift fuer die Gesamte Staatswissenschaft, 155(4): 643-663.

Halal, W.E. (1988). “The New Capitalism,” Futurist, 22(1): 26-32.

Hall, R.E. and Jones, C.I. (1999). "Why Do Some Countries Produce so Much More Output per Worker than Others?" Quarterly Journal of Economics, 114(1): 83-116.

Hamid, A. (2007). "Military Expenditures and Inequality: Empirical Evidence from Global Data," Defense and Peace Economics, 18(6): 519-535.

Hatton, T.J. and Williamson, J.A. (2009). Vanishing Third World Emigrants? Harvard University, Department of Economics, available at: http://www.economics.harvard.edu/faculty/williamson/ jwilliamworkingpapers . 
Hayek, F.A. (1945). “The Use of Knowledge in Society,” American Economic Review, 35(4): 519-530. -----, (1989). The Collected Works of F.A. Hayek [W.W. Bartley III. (ed.)].Chicago, Ill.: University of Chicago Press.

Haynes, J. (2001). “Transnational Religious Actors and International Politics," Third World Quarterly, 22(2): 143-158.

Heintz, P. (1972). A Macrosociological Theory of Societal Systems, with Special Reference to the International System. Bern: H. Huber.

Helliwell, J.F. (1994). "Empirical Linkages between Democracy and Economic Growth," British Journal of Political Science, (April), 24: 225-248.

Heo, U. (1998). "Modeling the Defense-growth Relationship Around the Globe," Journal of Conflict Resolution, 42(5): 637-657.

Herkenrath M. (2003). Transnationale Konzerne im Weltsystem. Globale Unternehmen, Nationale Wirtschaftspolitik und das ProblemNachholender Entwicklung (Transnational Corporations in the World System. Global Enterprises, National Economic Policy and the Problem of Catching-up Development). Wiesbaden: Westdeutscher Verlag.

Herkenrath, M. and Bornschier, V. (2003). "Transnational Corporations in World Development - Still the Same Harmful Effects in an Increasingly Globalized World Economy?" Journal of World-systems Research, ix(1): 105-139. Available [online] at: http://jwsr. ucr. edu, issn 1076-156x.

Herkenrath, M., Koenig C., Scholtz, H., and Volken, T. (2005). "Convergence and Divergence in the Contemporary World System: An Introduction," International Journal of Comparative Sociology, 46(5/6): 363-382.

Hertz, E., Hebert, J.R., and Landon, J. (1994). "Social and Environmental Factors and Life Expectancy, Infant Mortality and Maternal Mortality Rates. Results of a Cross-national Comparison," Social Science and Medicine, 39(1): 105-114.

Heshmati, A. (2006a). "Measurement of a Multidimensional Index of Globalization," Global Economy Journal, 6(2): Paper 1.

-----, (2006b). "The World Distribution of Income and Income Inequality: A Review of the Economic Literature," Journal of World Systems Research, 12(1): 61-107.

------, (2007). Global Trends in Income Inequality. Hauppauge, New York: Nova Science Publishers.

Heshmati, A. and Tausch, A. (eds.) (2007). Roadmap to Bangalore? Globalization, the EU's Lisbon Process and the Structures of Global Inequality. Haupauge, New York, NY: Nova Science Publishing.

Holmberg, S., Rothstein, B., and Nasiritousi, N. (2009). "Quality of Government: What You Get," Annual Review of Political Science, 12: 135-161.

Huntington, S.P. (1968). Political Order in Changing Societies. New Haven: Yale University Press.

-----, (1996). The Clash of Civilizations and the Remaking of World Order. New York: Simon and Schuster.

IMF (2009). World Economic Outlook Database. Available [online] at: http://www.imf.org/external/ pubs/ft/weo/2009/01/weodata/download.aspx.

Jorgenson, A.K. (2003). "Consumption and Environmental Degradation: A Cross-national Analysis of the Ecological Footprint," Social Problems, 50(3): 374-394. 
-----, (2004). "Global Inequality, Water Pollution, and Infant Mortality," The Social Science Journal, 41(2): 279-288.

------, (2004). "Uneven Processes and Environmental Degradation in the World- economy," Human Ecology Review, 11(2): 103-117.

------, (2005). "Unpacking International Power and the Ecological Footprints of Nations: A Quantitative Cross-national Study," Sociological Perspectives, 48(3): 383-402.

------, (2006). "Global Warming and the Neglected Greenhouse Gas: A Cross-national Study of the Social Causes of Methane Emissions Intensity, 1995," Social Forces, 84(3): 1779-1798.

------, (2006). "Unequal Ecological Exchange and Environmental Degradation: A Theoretical Proposition and Cross-National Study of Deforestation, 1990-2000," Rural Sociology, 71(4): 685-712.

------, (2007). "Does Foreign Investment Harm the Air We Breathe and the Water We Drink? A Cross-national Study of Carbon Dioxide Emissions and Organic Water Pollution in Less-developed Countries, 1975 to 2000," Organization and Environment, 20(2): 135-157.

------, (2007). "Foreign Direct Investment and Pesticide Use Intensity in Less-developed Countries: A Quantitative Investigation,” Society and Natural Resources, 20(1): 73-83.

-----, (2008). "Structural Integration and the Trees: An Analysis of Deforestation in Less-developed Countries, 1990-2005," The Sociological Quarterly, 49(3): 503-527.

------, (2009a). "Foreign Direct Investment and the Environment, the Mitigating Influence of Institutional and Civil Society Factors, and Relationships between Industrial Pollution and Human Health," Organization and Environment, 22(2): 135-157.

-----, (2009b). "Political-Economic Integration, Industrial Pollution and Human Health A Panel Study of Less-developed Countries, 1980-2000," International Sociology, 24(1): 115-143.

-----, (2009c). "The Sociology of Unequal Exchange in an Ecological Context: A Panel Study of Lower-income Countries, 1975-2000," Sociological Forum, 24(1): 22-46.

------, (2009d). "The Transnational Organization of Production, the Scale of Degradation, and Ecoefficiency: A Study of Carbon Dioxide Emissions in Less-developed Countries," Human Ecology Review, 16(1): 64-74.

Jorgenson, A.K. and Burns, T.J. (2007). "The Political-Economic Causes of Change in the Ecological Footprints of Nations, 1991-2001: A Quantitative Investigation,” Social Science Research, 36(2): 834-853.

, (2004). "Globalization, the Environment, and Infant Mortality: A Cross-national Study," Humboldt Journal of Social Relations, 28(1): 7-52.

Jorgenson, A.K. and Clark, B. (2009). The Economy, Military, and Ecologically Unequal Exchange Relationships in a Comparative Perspective: A Panel Study of the Ecological Footprints of Nations, 1975-2000," Social Problems, 56(4): 621-646.

Jorgenson, A.K. and Kuykendall, K.A. (2008). "Globalization, Foreign Investment Dependence and Agriculture Production: Pesticide and Fertilizer Use in Less-developed Countries, 1990-2000," Social Forces, 87(1): 529-560.

Jorgenson, A. K., Austin, K., and Dick, C. (2009). "Ecologically Unequal Exchange and the Resource Consumption/Environmental Degradation Paradox," International Journal of Comparative Sociology, 50(3/4): 263-284. 
Jorgenson, A.K., Dick, C., and Mahutga, M.C. (2007). "Foreign Investment Dependence and the Environment: An Ecostructural Approach," Social Problems, 54(3): 371-394.

Kakwani, N. (1993). "Performance in Living Standards: An International Comparison," Journal of Development Economics, 41(2): 307-336.

------, (1995). "Structural Adjustment and Performance in Living Standards in Developing Countries," Development and Change, 26(3): 469-502.

Kalecki, M. (1943). “Political Aspects of Full Employment,” Political Quarterly, 14 (4): 322-331.

-----, (1966). Studies in the Theory of Business Cycles, 1933-1939. New York: A.M. Kelley.

-----, (1968). Theory of Economic Dynamics: An Essay on Cyclical and Long-run Changes in Capitalist Economy. New York: Monthly Review Press.

------, (1968). “Trend and Business Cycle Reconsidered,” The Economic Journal, 78 (310): 263-276.

-----, (1971). Selected Essays on the Dynamics of the Capitalist Economy 1933-1970. Cambridge: Cambridge University Press.

------, (1979). Essays on Developing Economies, with an Introduction by Professor Joan Robinson. Hassocks, Sussex: The Harvester Press.

------, (1996). "The Maintenance of Full Employment after the Transition Period: A Comparison of the Problem in the United States and United Kingdom (Reprinted from International Labour Review, vol. 52, 1945)," International Labour Review, 135(3/4): 359-365.

Kalecki, M. and Feiwel, G.R. (1972). The Last Phase in the Transformation of Capitalism. New York: Monthly Review Press.

Kamarck, A.M. (1976). The Tropics and Economic Development: A Provocative Inquiry into the Poverty of Nations. Baltimore: Johns Hopkins.

Kearney, A.T., Inc. and the Carnegie Endowment for International Peace (2002). "Globalizations' Last Hurrah?" Foreign Policy, (January/February): 38-51.

-----, (2003). “Measuring Globalization: Who's Up, Who’s Down?” Foreign Policy,January/February: 60-72.

Kentor J. (1998). "The Long-term Effects of Foreign Investment Dependence on Economic Growth 1940-1990," American Journal of Sociology, 103(4): 1024-1046.

Kentor, J. and Boswell, T. (2003). "Foreign Capital Dependence and Development: A New Direction," American Sociological Review, 68(2): 301-313.

Kerbo H. (2005a). "Foreign Investment and Disparities in Economic Development and Poverty Reduction: A Comparative-Historical Analysis of the Buddhist Countries of Southeast Asia," International Journal of Comparative Sociology, 46: 425-459.

-----, (2005b). World Poverty: The Roots of Global Inequality and the Modern World System. New York: McGraw-Hill.

Khan, H. (1991). "Measurement and Determinants of Socioeconomic Development," Social Indicators Research, 24(2): 153-175.

King, L.A. (1998). "Economic Growth and Basic Human Needs, International Studies Quarterly, 42(2): 385-400. 
Klitgaard, R. and Fedderke, J. (1995). "Social Integration and Disintegration: An Exploratory Analysis of Cross-country Data," World Development, 23 (3): 357-369.

Knight, K.W. and Rosa, E.A. (2011). "The Environmental Efficiency of Well-being: A Cross-national Analysis,” Social Science Research, 40(3): 931-949.

Kohler, G. and Tausch, A. (2001). Global Keynesianism: Unequal Exchange and Global Exploitation. Huntington, NY: Nova Science Publishers.

Kohr, L. (1957). The Breakdown of Nations. New York: Rinehart.

-----, (1958). “The Velocity Theory of Population,” Land Economics, 34(2): 178-181.

-----, (1960). “The History of the Common Market,” The Journal of Economic History, 20(3): 441-454.

-----, (1977). The Overdeveloped Nations: The Diseconomies of Scale. New York: Schocken Books.

-----, (1992). “Leopold Kohr on the Desirable Scale of States," Population and Development Review, 18(4): 745-750.

Kormendi, R.C. and Meguire, P. (1985). "Macroeconomic Determinants of Growth: Cross-country Evidence," Journal of Monetary Economics, 16(2): 141-163.

Korotayev, A.V. and Tsirel, S.V. (2010). "A Spectral Analysis of World GDP Dynamics: Kondratieff Waves, Kuznets Swings, Juglar and Kitchin Cycles in Global Economic Development, and the 20082009 Economic Crisis," Structure and Dynamics, 4(1), Retrieved from:http://www.escholarship.org/ uc/item/9jv108xp

Krasilshchikov, V. (2008). The Rise and Decline of Catching Up Development: An Experience of Russia and Latin America with Implications for Asian Tigers. Entelequia, Revista Interdisciplinar, e-books, Málaga. Available [online] at: http://www.eumed.net/entelequia/en.lib.php?a=b008.

Kuznets, S. (1940). “Schumpeters Business Cycles,” The American Economic Review, 30(2): 157-69.

-----, (1955). “Economic Growth and Income Inequality," American Economic Review, 45(1): 1-28.

-----, (1976). Modern Economic Growth: Rate, Structure and Spread. New Haven, CT: Yale University Press.

La Porta, R., Lopez de Silanes, F., and Shlejfer, A. et al. (1999). “The Quality of Government,” Journal of Law, Economics and Organization, 15(1): 222-279.

Laver, M. and Shepsle, K.A. (1999). "Understanding Government Survival: Empirical Exploration or Analytical Models?” British Journal of Political Science, 29(2): 395-401.

Lawrence, K.S. (2009). “The Thermodynamics of Unequal Exchange," International Journal of Comparative Sociology, 50(3/4): 335-359.

Levine, R.E. and Renelt, D. (1992). "Sensitivity Analysis of Cross-country Growth Regressions," The American Economic Review, 82(4): 942-963.

Longo, F. (2008). Quality of Governance: Impartiality Is Not Enough,” Governance. An International Journal of Policy Administration and Institutions. 21(2): 191-196.

Longo, S. and York, R. (2008). "Agricultural Exports and the Environment: A Cross-national Study of Fertilizer and Pesticide Consumption," Rural Sociology, 73(1): 82-104.

Mahutga, M.C. and Bandelji, N. (2008). "Foreign Investment and Income Inequality: The Natural Experiment of Central and Eastern Europe," International Journal of Comparative Sociology, 49(6): 429-454. 
Mandelbaum, K. (1945). The Industrialisation of Backward Areas (assisted by J. R.L. Schneider). Oxford: B. Blackwell.

Mankiw, N.G., Romer, D., and Weil, D.N. (1992). "A Contribution to the Empirics of Economic Growth," Quarterly Journal of Economics, 107(2): 407-437.

Martin, P. and Straubhaar, T. (2002). "Best Practices to Reduce Migration Pressures," International Migration, 40(3): 5-23.

Massey, D.S. et al. (1993). “Theories of International Migration: A Review and Appraisal." Population and Development Review, 19(3): 431-466

Matt, A. (2010). "Good Government Means Different Things in Different Countries," Governance. An International Journal of Policy Administration and Institutions, 23(1): 7-35.

Mazumdar, K. (1996). "An Analysis of Causal Flow between Social Development and Economic Growth: The Social Development Index," American Journal of Economics and Sociology, 55(3): 361-383.

-----, 2000). "Causal Flow between Human Well-being and Per Capita Real Gross Domestic Product," Social Indicators Research, 50(3): 297-313.

McDowell, L. (1992). "Doing Gender. Feminism, Feminists and Research Methods in Human Geography," Transactions of the Institute of British Geographers, 17(4): 399-416.

Meadows, D.H. (1992). “Smart Development, Not Dumb Growth,” Technology Review, 95(6): 68-89.

Mintz, A. and Stevenson, R.T. (1995). "Defense Expenditures, Economic Growth, and the Peacedividend. A Longitudinal Analysis of 103 Countries," Journal of Conflict Resolution, 39(2): 283-305.

Molle, W. and Boeckhout, S. (1995). "Economic Disparity Under Conditions of Integration. A Longterm View of the European Case," Papers in Regional Science, 74(2): 105-123.

Moon, B.E. and Dixon, W.J. 1992. "Basic Needs and Growth Welfare Trade-Offs," International Studies Quarterly, 36(2): 191-212.

Mostafa, M.M. (2010a). A Bayesian Approach to Analyzing the Ecological Footprint of 140 Nations," Ecological Indicators, 10(4): 808-817.

------, (2010b). "Clustering the Ecological Footprint of Nations Using Kohonens Self-organizing Maps," Expert Systems with Applications, 37(4): 2747-2755.

Mostafa, M.M. and Nataraajan, R. (2009). A Neuro-computational Intelligence Analysis of the Ecological Footprint of Nations," Computational Statistics and Data Analysis, 53(9): 3516-3531.

Newman, B.A. and Thomson, R.J. (1989). "Economic Growth and Social Development. A Longitudinal Analysis of Causal Priority," World Development, 17(4): 461-471.

Ng, Y-K. (2008a). "Environmentally Responsible Happy Nation Index: Towards an Internationally Acceptable National Success Indicator," Social Indicators Research, 85(3): 425-446.

------, (2008b). "Happiness Studies: Ways to Improve Comparability and Some Public Policy Implications," Economic Record, (June), 84: 253-266.

Nugent, C. and Shandra, J.M. (2009). "State Environmental Protection Efforts, Womens Status, and World Polity. A Cross-national Analysis,” Organization and Environment, 22(3) 293-310.

Orloff, A. (1996). "Gender in the Welfare State," Annual Review of Sociology, 22: 51-78.

Oswald, A.J. (1997). “Happiness and Economic Performance,” Economic Journal, 107(445): 1815-1831. 
Paya, I., Venetis, I.A., and Peel, D.A. (2003). "Further Evidence on PPP Adjustment Speeds: The Case of Effective Real Exchange Rates and the EMS," Oxford Bulletin of Economics and Statistics, 65(4): 421-437.

Poe, S.C. and Tate, C.N. (1994). "Repression of Human Rights to Personal Integrity in the 1980s. A Global Analysis," American Political Science Review, 88(4): 853-872.

Poza, E. (1989). Smart Growth: Critical Choices for Business Continuity and Prosperity. San Francisco: Jossey-Bass.

Prebisch, R. (1950). The Economic Development of Latin America and Its Principal Problems. Economic Commission for Latin America, New York: United Nations Department of Economic Affairs.

Prebisch, R. (1983). "The Crisis of Capitalism and International Trade," ECLAC Review/Revista de la CEPAL (Santiago), (August), 20: 51-74.

Prebisch, R. (1988). "Dependence, Development, and Interdependence," in G. Ranis and T.P. Schultz (eds.). The State of Development Economics: 31-41. Oxford, United Kingdom: Basil Blackwell.

Ram, R. (1982). "Composite Indices of Physical Quality of Life, Basic Needs Fulfillment, and Income. A Principal Component Representation,” Journal of Development Economics, 11(2): 227-247.

-----, (1986). "Government Size and Economic Growth. A New Framework and Some Evidence from Cross-section and Time-series Data," American Economic Review, 76(1): 191-203.

------, (1997). “Tropics and Development: an Empirical Investigation,” World Development, 25(9): $1443-1452$.

Rankin, K.N. (2002). "Social Capital, Microfinance, and the Politics of Development," Feminist Economics, 8(1): 1-24.

Rennstich, J. (2007). "Is Globalization Self-organizing?" in G. Modelski, T.C. Devezas, and W.R. Thompson (eds.), Globalization as Evolutionary Process. Modeling Global Change: 74-107. London and New York: Routledge.

Reuveny, R. and Li, Q. (2003). "Economic Openness, Democracy, and Income Inequality: An Empirical Analysis," Comparative Political Studies, 36(5): 575-601.

Reuveny, R. and Thompson, W.W. (2004). "World Economic Growth, Systemic Leadership, and Southern Debt Crises," Journal of Peace Research, 41(1): 5-24.

Rodriguez, F. and Rodrik, D. (2001). "Trade Policy and Economic Growth: A Sceptics Guide to the Cross-national Evidence," in B.S. Bernanke and K. Rogoff (eds.) NBER Macroeconomics Annual 2000: (261-338), Cambridge, MA: MIT Press.

Rodrik, D. (2006). "Goodbye Washington Consensus, Hello Washington Confusion? A Review of the World Bank's Economic Growth in the 1990s: Learning from a Decade of Reform," Journal of Economic Literature, 44: 973-987.

Rodrik, D., Subramanian, A., and Trebbi, F. (2004). "Institutions Rule: The Primacy of Institutions over Geography and Integration in Economic Development," Journal of Economic Growth, 9(2): 131-165.

Rondinelli, D.A. (1987). "Export Processing Zones and Economic Development in Asia. A Review and Reassessment of a Means of Promoting Growth and Jobs," American Journal of Economics and Sociology, 46(1): 89-105.

Rosenstein-Rodan, P.N. (1964). Capital Formation and Economic Development. London: Allen and Unwin. 
Ross, R.J.S. (2004). Slaves to Fashion. Poverty and Abuse in the New Sweatshops. Ann Arbor: University of Michigan Press.

Rothschild, K.W. (1944). “The Small Nation and World Trade, The Economic Journal, (April): 26-40.

-----, (1954). The Theory of Wages. Oxford: Blackwell.

------, (1957). "Der Lohnanteil am Gesamteinkommen: Einige Bemerkungen zu einem Umstrittenen Problem (The Share of Wages in National Income. Some Remarks about a much Debated Problem)," Weltwirtschaftliches Archiv, 78(2): 157-202.

------, (1958). "Einkommensbildung und Einkommensverteilung (Income Formation and Income Distribution)," Weltwirtschaftliches Archiv, 80(2): 53-58.

------, (1959). “The Limitations of Economic Growth Models,” Kyklos, 12(4): 567-588.

-----, (1964). "Surveys of Foreign Postwar Developments in Economic Thought," The American Economic Review, 54(2): 1-55.

-----, (1965). "Theme and Variations, Remarks on the Kaldorian Distribution Formula," Kyklos, 18(4): 652-669.

Rothstein, B. and Teorell, J. (2008). "What is Quality of Government? A Theory of Impartial Government Institutions," Governance. An International Journal of Policy Administration and Institutions, 21(2): 165-190.

Rubinson, R. (1976). "The World Economy and the Distribution of Income within States - a Crossnational Study," American Sociological Review, 41 (4): 638-659.

Rudra, N. (2009). "Why International Organizations Should Bring Basic Needs Back In,” International Studies Perspectives, 10(2): 129-150.

Sala-i-Martin, X. (1997). "I Just Ran Two Million Regressions," The American Economic Review, 87(2): 178-183. Papers and Proceedings of the Hundred and Fourth Annual Meeting of the American Economic Association, May.

Sala-i-Martin, X., Doppelhofer, G., and Miller, R.I. (2004). "Determinants of Long-term Growth: A Bayesian Averaging of Classical Estimates (BACE) Approach," American Economic Review, 94(4): 813-835.

Samuelson, P. (1964). "Theoretical Notes on Trade Problems," Review of Economics and Statistics, 46: $145-154$.

Sanderson, M. (2010). International Migration and Human Development in Destination Countries: A Cross-national Analysis of Less-developed Countries, 1970-2005," Social Indicators Research, 96(1): 59-83.

Sanderson, M.R. and Kentor, J. (2008). "Foreign Direct Investment and International Migration: A Cross-national Analysis of Less-developed Countries, 1985-2000," International Sociology, 23(4): 514-539.

Sanderson, M.R. and Kentor, J.D. (2009). "Globalization, Development and International Migration: A Cross-national Analysis of Less-developed Countries, 1970-2000," Social Forces, 88(1): 301-336.

Scanlan, S. (2004). "Women, Food Security, and Development in Less-industrialized Societies: Contributions and Challenges for the New Century," World Development, 32(11): 1807-1829.

Schumacher, E.F. (1973a). Small is Beautiful: Economics as if People Mattered. New York: Harper and Row. 
------, (1973b). “Western Europe's Energy Crisis: A Problem of Life-Style,” Ambio, 2(6): 228-232.

------, (1976). "Patterns of Human Settlement," Ambio, 5(3): 91-97.

------, (1977). A Guide for the Perplexed. New York: Harper and Row.

Schumpeter, J.A. (1908). Wesen und Hauptinhalt der Theoretischen Nationalökonomie (The Nature and Essence of Economic Theory). Leipzig: Duncker and Humblot.. (Rutgers, New Jersey: Transaction Publishers, 2009).

------, (1912). Theorie der wirtschaftlichen Entwicklung Leipzig: Duncker and Humblot [The Theory of Economic Development: An Inquiry into Profits, Capital, Credit, Interest and the Business Cycle. R. Opie (trans.). Cambridge (Mass.): Harvard University Press, 1934].

-----, (1939). Business Cycles. A Theoretical, Historical, and Statistical Analysis of the Capitalist Process. New York, London: McGraw-Hill Book Company.

------, (1942). The Process of Creative Destruction. London: Unwin.

------, (19509. Capitalism, Socialism and Democracy. New York and London: Harper and Row

-----, (1954). History of Economic Analysis. New York: Oxford University Press.

Seers, D. and Ostrom, K. (eds.) (1983) The Crises of the European Regions. London: Macmillan in association with the European Association of Development Institutes.

Seers, D. (ed.) (1981). Dependency Theory: A Critical Reassessment. London: Pinter.

Seers, D., Schaffer, B., and Kiljunen, M.L. (1979). Underdeveloped Europe: Studies in Core-periphery Relations. Atlantic Highlands, NJ: Humanities Press.

Seers, D. and Vaitsos, C. with the assistance of Kiljunen, M.L. (1980). Integration and Unequal Development: The Experience of the EEC. London: Macmillan.

Selden, T.M. and Song, D.Q. (1994). "Environmental Quality and Development. Is There a Kuznets Curve for Air Pollution Emissions?" Journal of Environmental Economics and Management, 27(2): $147-162$.

Shandra, J.M. (2007a). "Economic Dependency, Repression, and Deforestation: A Quantitative, Cross-national Analysis," Sociological Inquiry, 77(4): 543-571.

-----, (2007b). "International Nongovernmental Organizations and Deforestation: Good, Bad, or Irrelevant?" Social Science Quarterly, 88(3): 665-689.

Shandra, J.M., Leckband, C., and London, B. (2009). "Ecologically Unequal Exchange and Deforestation: A Cross-national Analysis of Forestry Export Flows," Organization and Environment, 22(2): 208-229.

Shandra, J.M., Leckband, Ch., McKinney, L.A., and London, B. (2009). "Ecologically Unequal Exchange, World Polity, and Biodiversity Loss. A Cross-national Analysis of Threatened Mammals," International Journal of Comparative Sociology, 50(3/4): 285-310.

Shandra, J.M., London, B., Whooley, O.P., and Williamson, J.B. (2004). International Nongovernmental Organizations and Carbon Dioxide Emissions in the Developing World: A Quantitative, Cross-national Analysis," Sociological Inquiry, 74(4): 520-545.

Shandra, J.M., London, B., and Williamson, J.B. (2003). "Environmental Degradation, Environmental Sustainability, and Over Urbanization in the Developing World: A Quantitative, Cross-national Analysis," Sociological Perspectives, 46(3): 309-329. 
Shandra, J.M., Nobles, J.E., London, B., and Williamson, J.B. (2004). "Dependency, Democracy, and Infant Mortality: A Quantitative, Cross-national Analysis of Less Developed Countries," Social Science and Medicine, 59(2): 321-333.

------, (2005). "Multinational Corporations, Democracy and Child Mortality: A Quantitative, Crossnational Analysis of Developing Countries," Social Indicators Research, 73(2): 267-293.

Shandra, J.M., Shandra, C.L. and London, B. (2008). Women, Non-governmental organizations, and Deforestation: A Cross-national Study," Population and Environment, 30(1/2): 48-72.

-----, (2010). "Do Non-governmental Organizations Impact Health? A Cross-national Analysis of Infant Mortality," International Journal of Comparative Sociology, 51(1/2): 137-164.

Shandra, J.M., Shor, E. and London, B. (2008). "Debt, Structural Adjustment, and Organic Water Pollution," Organization and Environment, 21(1): 38-55.

------, (2009). "World Polity, Unequal Ecological Exchange, and Organic Water Pollution: A Crossnational Analysis of Developing Nations," Human Ecology Review, 16(1): 53-63.

Singa Boyenge, J-P (2007). ILO Database on Export Processing Zones (Revised), WP. 251; Sectoral Activities Programme, Working Paper, International Labour Office, Geneva, April.

Singer, H.W. (1975). The Strategy of International Development: Essays in the Economics of Backwardness [A.Cairncross and M. Puri (eds.)]. London: Macmillan.

Singer, H.W. and Ansari, J.A. (1988). Rich and Poor Countries: Consequences of International Economic Disorder. London, Boston: Unwin Hyman.

Singer, H.W. and Roy, S. (1993). Economic Progress and Prospects in the Third World: Lessons of Development Experience since 1945. Aldershot, England; Brookfield, Vt., USA: E. Elgar.

Singh, R.D. (1985). "State Intervention, Foreign Economic Aid, Savings and Growth in LDCs. Some Recent Evidence," Kyklos, 38(2): 216-232.

Skaggs, K.A.S. 2010. "Implications of Emerging Neoliberal Politics on Conservation Governance in the South Carolina Low Country. Masters Abstracts International, 48(6): 33-85.

SPSS (2007). Statistical Package for the Social Sciences, User Guide. Version 14, August.

Stavins, R.N. (2002). Experience with Market-based Environmental Policy Instruments. FEEM Working Paper No. 52; KSG Working Paper No. 00-004. Available [online] at: SSRN: http://ssrn. com/abstract $=199848$ or doi: $10.2139 /$ ssrn. 199848

Steindl, J. (1952). Maturity and Stagnation in American Capitalism. Oxford: Basil Blackwell.

-----, (1979). “Stagnation Theory and Stagnation Policy," Cambridge Journal of Economics, (3): 1-14.

, (1988). "Diskussionsbeitrag zur EG-Frage (A Contribution for the Debate about the European Community)," Kurswechsel, 4(3): 3-7.

(1990). Economic Papers 1941-88. Basingstoke: MacMillan.

Stern, D.I. (2004). "The Rise and Fall of the Environmental Kuznets Curve," World Development, 32(8): 1419-1439.

Stern, D.I., Common, M.S., and Barbier, E.B. (1996). "Economic Growth and Environmental Degradation: The Environmental Kuznets Curve and Sustainable Development," World Development, 24(7): 1151-1160. 
Stevenson, B. and Wolfers, J. (2008). "Economic Growth and Subjective Well-being: Reassessing the Easterlin Paradox," IZA Discussion Paper Series, IZA DP No. 3654, IZA Bonn. Available [online] at: http://ftp.iza.org/dp3654.pdf

Sunkel, O. (1966). "The Structural Background of Development Problems in Latin America," Weltwirtschaftliches Archiv, 97(1): 22-63.

-----, (1973). "Transnational Capitalism and National Disintegration in Latin America," Social and Economic Studies, 22(1): 132-76.

-----, (1978). “The Development of Development Thinking,” in J.J. Villamil (ed.) Transnational Capitalism and National Development. New Perspectives on Dependence: 19-30. Hassocks, Sussex: Harvester Press.

Sunkel, O. (ed.) (2003). Development from Within: Toward a Neostructuralist Approach for Latin America. Boulder, CO: L. Rienner.

Sylwester, K. (2000). Income Inequality, Education Expenditures, and Growth," Journal of Development Economics, 63(2): 379-398.

Tausch, A. (2003). "Social Cohesion, Sustainable Development and Turkey's Accession to the European Union: Implications from a Global Model," Alternatives. Turkish Journal of International Relations, 2(1): 2003.

-----, (2005). “Is Islam Really a Development Blockade?” Insight Turkey, 7(1): 124-135.

------, (2007). "Quantitative World System Studies Contradict Current Islamophobia: World Political Cycles, Global Terrorism, and World Development," Alternatives: Turkish Journal of International Relations, 6(1)-2: 15-81.

------, (2007). "War Cycles," Social Evolution and History (Moscow), 6(2): 39-74.

------, (2008). “Разрушительное созидание?” (Рассуждения в духе Шумпетера некоторых трендах и Лиссабонском процессе в Европе) [Destructive Creation (Schumpeter-Style Reasonings on Some Trends and Lisbon Process in Europe)]. Mirovaja Ekonomika i Meždunarodnyje Otnošenija, (Moscow), 10: 34-41.

-----, (2010). "Dataset for 'Globalization, the Human Condition and Sustainable Development in the 21st Century. Cross-national Perspectives and European Implications." Available [online] at http:// www.hichemkaroui.com/?p=2383 Social Sciences and Humanities

- MESOJ (Middle East Studies Online Journal, 1(2) - ISSN 2109-9618).

Tausch, A. and Ghymers, C. (2006). From the "Washington" towards a "Vienna Consensus?" A Quantitative Analysis on Globalization, Development and Global Governance. Hauppauge, NY: Nova Science.

Tausch, A. and Prager, F. (1993). Towards a Socio-Liberal Theory of World Development. Basingstoke and New York: Palgrave Macmillan/St. Martins Press.

Taylor, A.M. (1992). "External Dependence, Demographic Burdens, and Argentine Economic Decline after the Belle Epoque," Journal of Economic History, 52(4): 907-936.

Taylor, J.E. (1999). "The New Economics of Labour Migration and the Role of Remittances in the Migration Process," International Migration, 37(1): 63-88.

------, (2006). International Migration and Economic Development. 
UN/POP/MIG/SYMP/2006/09, 26 June 2006, International Symposium on InternationalMigration and Development, Population Division, Department of Economic and Social Affairs, United Nations Secretariat, Turin, Italy, 28-30 June 2006. Available [online] at: http://www.un.org/esa/population/ migration/turin/Symposium_Turin_files/P09_SYMP_Taylor.pdf

Tsai, P.L. (1995). "Foreign Direct Investment and Income Inequality: Further Evidence," World Development, 23 (3): 469-483.

United Nations (current issues) United Nations Human Development Report. New York and Oxford: Oxford University Press.

United Nations Conference on Trade and Development (2009). World Investment Report. New York and Geneva: United Nations.

United Nations Economic Commission for Latin America, ECLAC/CEPAL, (2002). Globalización y Desarrollo (Globalization and Development). Available [online] at: http://www.eclac.cl/cgibin/getProd. asp?xml=/publicaciones/xml/6/10026/P10026.xml\&xsl=/tpl/p9f.xsl\&base=/MDG/tpl/top-bottom.xsl.

Veenhoven, R. (1996). "Happy Life-expectancy. A Comprehensive Measure of Quality-of-Life in Nations," Social Indicators Research, 39: 1-58.

Wallerstein, I. (2000). The Essential Wallerstein. New York: The New Press.

Weede, E. (1980). "Beyond Misspecification in Sociological Analyses of Income Inequality," American Sociological Review, 45: 497-501.

, (1981a). "Dependency Theories and Economic Growth: A Cross-national Study," Koelner Zeitschrift fur Soziologie und Sozialpsychologie, 33(4): 690-707.

------, (1981b). "Militär, Multis und Wirtschaft . Schweizerische Zeitschrift für Soziologie/Revue Suisse de Sociologie, 7(1): 113-127. [The Military Multinationals and the Economy. No English version available]

-----, (1983). "Military Participation Ratio. Human Capital Formation and Economic Growth: A Cross-national Analysis," Journal of Political and Military Sociology, 11: 11-29.

------, (1985). Entwicklungsländer in der Weltgesellschaft . Opladen: Westdeutscher Verlag. [Developing countries in world society. No English version available].

------, (1986). "Rent Seeking, Military Participation and Economic Performance in LDCs," Journal of Conflict Resolution, 30: 291-314.

-----, (1993). "The Impact of Military Participation on Economic Growth and Income Inequality: Some New Evidence," Journal of Political and Military Sociology, 21: 241-258.

------, (2002). “Impact of Intelligence and Institutional Improvements on Economic Growth,” Kyklos, 55(3): 361-380.

------, (2004). "Does Human Capital Strongly Affect Economic Growth Rates? Yes, But Only If Assessed Properly," Comparative Sociology, 3(2): 115- 134.

Weede, E. and Jagodzinski, W. (1980). "Weltpolitische und ökonomische Determinanten einer ungleichen Einkommensverteilung. Eine international vergleichende Studie (World Political and Economic Determinants of an Unequal Distribution of Incomes)Zeitschrift für Soziologie, 9: 132-148.

Weede, E. and Kampf, S. (2002). The Impact of Intelligence and Institutional Improvements on Economic Growth," Kyklos, 55(3): 361-380. 
Weede, E. and Tiefenbach, H. (1980a). "Correlates of the Size Distribution of Income in Cross-national Analyses," Journal of Politics, 43(4): 1029-1041.

-----, (1980b). "Some Recent Explanations of Income Inequality: An Evaluation and Critique," International Studies Quarterly, 25: 255-282.

------, (1981). “Three Dependency Explanations of Economic Growth: A Critical Evaluation,” European Journal of Political Research, 9(4): 391-406.

Wilkinson R.G. and Picket K.E. (2006). "Income Inequality and Population Health: A Review and Explanation of the Evidence," British Medical Journal, BMJ, 62(7): 1768-1784.

Wilkinson, R.G. (1992). "For Debate - Income Distribution and Life Expectancy," British Medical Journal, BMJ, 304(6820): 165-168.

-----, (1997). "Socioeconomic Determinants of Health - Health Inequalities: Relative or Absolute Material Standards?" British Medical Journal, BMJ, 314(7080): 591-595.

Williamson, J.A. (2002). Is Protection Badfor Growth? Will Globalization Last? Looking for Answers in History. Presented at the $13^{\text {th }}$ IEHA Congress, Buenos Aires, August 22-26.Available [online] at: http://www. economics. harvard. edu/faculty/williamson/jwilliamworkingpapers

World Bank. (2005). Economic Growth in the 1990s: Learning from a Decade of Reform. Washington, DC: World Bank.

York, R., Rosa, E.A., and Dietz, T. (2003). "Footprints on the Earth: The Environmental Consequences of Modernity," American Sociological Review, 68(2): 279-300.

Ziesemer, T.H.W. (2009). "Worker Remittances and Growth: The Physical and Human Capital Channels," Jahrbuecher fuer Nationaloekonomie und Statistik, 229(6): 743-773. 